\title{
MASTER
}

GJBX́-4(80)

National Uranium Resource Evaluation

\section{HIGH RESOLUTION GAMMA-RAY \\ SPECTROSCOPY APPLIED TO \\ BULK SAMPLE ANALYSIS}

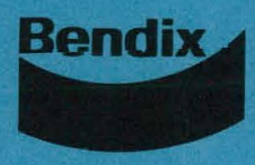

Field Enyineering Corporation

Grand Junction Operations Grand Junction, CO 81502

January 1980

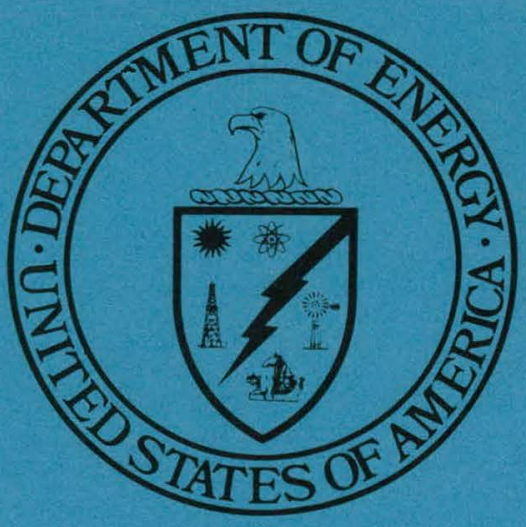

PREPARED FOR U.S. DEPARTMENT OF ENERGY

Assistant Secretary for Resource Applications

Grand Junction Office, Colorado 


\section{DISCLAIMER}

This report was prepared as an account of work sponsored by an agency of the United States Government. Neither the United States Government nor any agency Thereof, nor any of their employees, makes any warranty, express or implied, or assumes any legal liability or responsibility for the accuracy, completeness, or usefulness of any information, apparatus, product, or process disclosed, or represents that its use would not infringe privately owned rights. Reference herein to any specific commercial product, process, or service by trade name, trademark, manufacturer, or otherwise does not necessarily constitute or imply its endorsement, recommendation, or favoring by the United States Government or any agency thereof. The views and opinions of authors expressed herein do not necessarily state or reflect those of the United States Government or any agency thereof. 


\section{DISCLAIMER}

Portions of this document may be illegible in electronic image products. Images are produced from the best available original document. 
This report is a result of work performed by Bendix Field Engineering Corporation as part of the National Uranium Resource Evaluation. NURE is a program of the U.S. Department of Energy's Grand Junction, Colorado, Office to acquire and compile geologic and other information with which to assess the magnitude and distribution of uranium resources and to determine areas favorable for the occurrence of uranium in the United States.

This report was prepared as an account of work sponsored by the United States Government. Neither the United States nor the United States Department of Energy, nor any of their employees, nor any of their contractors, subcontractors, or their employees, makes any warranty, express or implied, or assumes any legal liability or responsibility for the accuracy, completeness, or usefulness of any information, apparatus, product, or process disclosed, or represents that its use would not infringe privately owned rights. 


\section{HIGH RESOLUTION GAMMA-RAY SPECTROSCOPY APPLIED TO BULK SAMPLE ANALYSIS}

Ken L. Kosanke

Chuck D. Koch

Robert D. Wilson

BENDIX FIELD ENGINEERING CORPORATION
Grand Junction Operations
P.O. Box 1569
Grand Junction, Colorado 81502

August 1978

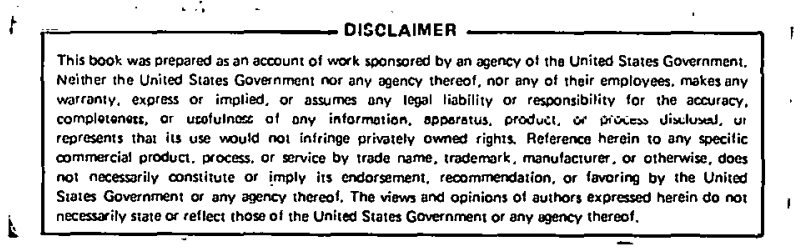

YKEYAKED FUK THE U.S. DEPARTMENT OF ENERGY Assistant Secretary for Resource Applications Grand Junction Office, Colorado Under Contract No. DE-AC13-76GJ01664 


\section{THIS PAGE \\ WAS INTENTIONALLY \\ LEFT BLANK}


Introduction.................................... 1

A. Ge(L1) Gamma-Ray Spectrometer...................... 3

1. System Configuration and Specifications............... 3

2. Low Background Shield........................... 3

3. Background Variations Due to Radon................... 6

4. Energy Linearity of the System.................... 6

5. System Stability............................. 6

6. Absolute Gamma Efficiency...................... 10

7. Live Time Clock Errors........................... 10

B. Library of $\mathrm{Ge}(\mathrm{Li})$ Spectra......................... 13

C. Ge(Li) Analysis Scheme for the "Near Term"............... 20

1. Analysis Scheme Description....................... 20

2. Example Using Analysis Scheme...................... 23

3. Preliminary Results Using Analysis Scheme.............. 27

D. Conclusions and Recommendations..................... 28

TABLES

Table 1. Reduction of Background Continuum in Ge(Li) Shielding Cave...................................... 5

Table 2. Reduction of Background Peaks in Ge(Li) Shielding Cave .... 5

Table 3. Comparison of Chemical and Radiometric $\mathrm{U}_{3} \mathrm{O}_{8}$ Assays; Radiometric Assays Utilize the $186 \mathrm{keV}$ Intensity from the Decay of $235_{U} \ldots \ldots \ldots \ldots \ldots \ldots \ldots \ldots \ldots \ldots \ldots \ldots \ldots . \ldots \ldots$

Table A-1. Some of the Prominent KUT Photopeaks Falling at Least Partially in the KUT Windows.....................A-7

Table A-2. Peak Identification for Figure A-3................... 


\section{FIGURES}

Page

Figure 1. Block Diagram of Present Ge(Li) Gamma Spectrometer......... .4

Figure 2. Linearity of ORTEC MCA Mode1 6240 Using a Berkeley Nucleonics Ramp Pulser Model GL 3.................... 7

Figure 3a. Short Term Stability of the ORTEC 6240 MCA............ 8

Figure 3b. Long Term Stability of the ORTEC 6240 MCA..............9

Figure 4. Absolute Efficiency of the 16.3 Percent Ge(Li)

Spectrometer as a Function of Energy ..........................11

Figure 5. Live Time Clock Errors in ORTEC 6240 MCA................. 1.2

Figure 6. Ge(Li) Spectrum of Equilibrium Uranium Ore............. 14

Figure 7. Ge(Li) Spectrum of Radium Rich (Depleted Uranium) Uranium Ore Sample..................................... 15

Figure 8. Ge(Li) Spectrum of Radium Depleted Uranium Ore Sample.... 16

Figure 9. Ge(Li) Spectrum of Equilibrium Thorium Ore Sample....... 17

Figure 10. Comparison of Low Energy Portions of Figures 6 through $9 \quad 18$

Figure 11. Ge( $\mathrm{Li}$ ) Spectrum of $40_{\mathrm{K}}$ as $\mathrm{K}_{2} \mathrm{CO}_{3} \ldots \ldots \ldots \ldots \ldots \ldots \ldots$

Figure 12. Graphic Presentation of Numerically Generated Weighted Least Squares Fit of the Ratios AF.................. 25

Figure A-1. Block Diagram of Geochemical Analytical Laboratory KUT Spectrometer.................................. A-3

Figure A-2. KUT Data Showing Window Placements. Data Collected in the Laboratory Using a Collection of $40_{\mathrm{K}}, 226_{\mathrm{Ra}}$, and $228_{\text {Th }}$ sources................................... A

Figure A-3. Comparison of $\mathrm{NaI}$ and $\mathrm{Ge}(\mathrm{Li})$ Detector Resolution............9-9

\section{APPE NDICES}

Appendix A. Description of Gamma Spectrometry as Applied to Laboratory Bulk Sample Analysis.................. A-1

Appendix B. Listing of Gamma Transitions in the ${ }^{238} \mathrm{U},{ }^{235} \mathrm{U}$, and 232 Th Decay Chains........................ B-1

Appendix C. Listing and Definitions of $\mathrm{U}_{3} \mathrm{O}_{8}$ Prefixes................................ c-1 


\section{INTRODUCTION}

On approximately January 1, 1975 an R\&D project was begun to introduce state-of-the-art techniques into potassium, uranium, and thorium gamma-ray spectroscopy. 1 The central elements of this system are a high resolution Ge(Li) detector and a multichannel analyzer with a sufficient number of channels to utilize the full resolving capability of the detector. The first major phase of this project included the assembly of the system, construction of a low background shield, determination of system parameters, and formulations of a near-term analysis scheme. This phase has been completed and it is the purpose of this report to document that work.

The $\mathrm{Ge}(\mathrm{Li})$ spectrometer system and its use for bulk sample potassium, uranium, and thorium analysis have been well characterized by the study reported here. The near-term analysis scheme permits the direct assay of uranium, in addition to the conventional equivalent uranium assay provided by sodium iodide spectrometers. This represents a significant improvement for BFEC in laboratory radiometric assay methods because the direct assay for uranium is independent of the uranium/radium disequilibrium condition.

${ }^{1}$. L. Kosanke, R\&D Project No. 5001, "Sample Assay Using a Ge(Li) Detector," Scptcmbcr, 1975. 


\section{THIS PAGE}

\section{WAS INTENTIONALLY LEFT BLANK}




\section{A. Ge(Li) Gamma-Ray Spectrometer}

This section of the report will discuss only the configuration and operation of the new Ge(Li) spectrometer. The present NaI KUT system will not be discussed in the main text of this report but is discussed as part of a general discussion of KUT spectrometry as applied to bulk samples in Appendix A.

\section{System Configuration and Specifications}

A block diagram of the present $\mathrm{Ge}(\mathrm{Li})$ spectrometer is shown in Figure 1. Equipment model numbers, along with pertinent specifications or operational parameters are tabulated below:

Ge(Li) detector: Princeton Gamma-Tech Resolution: $1.68 \mathrm{keV}$ (FWHM) @ $1.33 \mathrm{MeV}$

$3.16 \mathrm{keV}$ (FW.1M) @ $1.33 \mathrm{MeV}$

$0.67 \mathrm{keV}$ (PHIM) C $0.12 \mathrm{MeV}$

Efficiency: $16.3 \%$ (relative to 3 inch $x 3$ inch $N a I(T 1)$ at $25 \mathrm{~cm}$ ) Peak/Compton Ratio: 48:1 @ $1.33 \mathrm{MeV}$

Preamplifier: PGT-RG-11C

High Voltage Supply: Power Designs (AEC-5000)

Amplifier: Princeton Gamma-Tech

Shaping, 2 usec

Restorer, low

Output, DC-Unipolar-93 ohm

Multichannel Analyzer: ORTEC (6240)

409.6 channels

Computer: Digital Equipment (PDP-11/10)

$16 \mathrm{~K}$ core

Hard Copy Terminal: Digital Equipment (Decwriter II)

Plotter: Hewlett-Packard (7004B X-Y)

When count-rate information is required it is generated using a single channel analyzer and scaler.

\section{Low Background Shield}

In order to allow low-level counting, a low background shield was constructed. The shield was constructed using 2 inch by 4 inch by 8 inch lead bricks in a pattern chosen to eliminate cracks through the walls. Wall thicknesses are 6 inches on the top and sides and 4 inches on the bottom. In addition, the shield was graded on the inside using $1 / 4$ inch copper sheets to reduce fluoresced $\mathrm{Pb} X$-rays by a factor of $\sim 50$. Relatively thick copper sheets were chosen instead of thinner sheets of cadmium and copper because of cost and delivery time considerations. With the complete shield, the background was reduced by a factor of about 200 at $100 \mathrm{keV}$ and a factor of about 15 at $2500 \mathrm{keV}$. Reductions in the background continum and background peaks are listed in Tables 1 and 2 . 


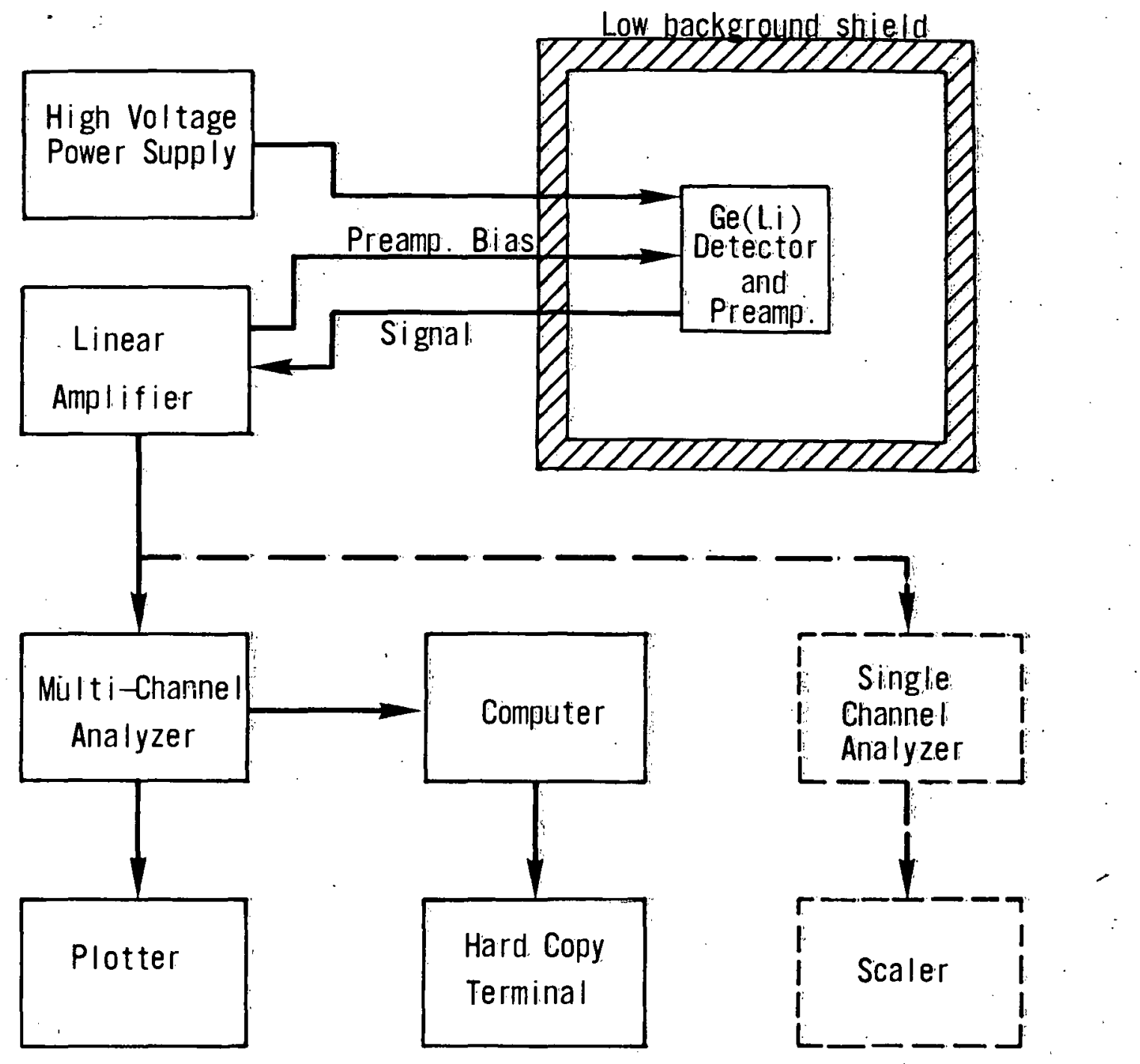

(Does not show $\mathrm{LN}_{2}$ level monitor.)

FIGURE 1. Block Diagram of Present Ge(Li) Gamma Spectrometer 
TABLE 1

Reduction of Background Continum in Ge(Li) Shielding Cave

\begin{tabular}{cccc}
$\begin{array}{c}\text { Energy } \\
(\mathrm{keV})\end{array}$ & \multicolumn{2}{c}{ Background Continuum Recorded } \\
\cline { 2 - 4 } & $\begin{array}{c}\text { Out of Cave } \\
(\mathrm{cpm} / \mathrm{keV})\end{array}$ & $\begin{array}{c}\text { In Cave } \\
(\mathrm{cpm} / \mathrm{keV})\end{array}$ & $\begin{array}{c}\text { Fractional Background } \\
\text { Reduction } \\
\text { (out of cave/in cave) }\end{array}$ \\
\hline 100 & $39.2(.13)$ & $0.19(.008)$ & $206(9)$ \\
200 & $17.5(.08)$ & $0.19(.008)$ & $92(4)$ \\
500 & $2.4(.03)$ & $0.055(.004)$ & $44(3)$ \\
1000 & $0.75(.02)$ & $0.014(.002)$ & $54(8)$ \\
1500 & $0.18(.009)$ & $0.008(.002)$ & $22(6)$ \\
2000 & $0.07(.005)$ & $0.003(.001)$ & $23(8)$ \\
2500 & $0.03(.003)$ & $0.002(.001)$ & $15(8)$
\end{tabular}

Notes: 1. ( ) indicates lo uncertainty.

2. Counts were taken for a time of 20,000 seconds.

TABLE 2

Reduction of Background Peaks in Ge(Li) Shielding Cave

\begin{tabular}{|c|c|c|c|c|}
\hline \multirow[b]{2}{*}{$\begin{array}{r}\text { Energy } \\
(\mathrm{keV}) \\
\end{array}$} & \multirow[b]{2}{*}{$\begin{array}{c}\text { Decay chain } \\
\text { of origin }\end{array}$} & \multicolumn{2}{|c|}{ Background Peaks Recorded } & \multirow{2}{*}{$\begin{array}{c}\text { Fractional Background } \\
\text { Reduction } \\
\text { (out of cave/in cave) }\end{array}$} \\
\hline & & $\begin{array}{c}\text { Out of cave } \\
(\mathrm{cpm})\end{array}$ & $\begin{array}{c}\text { In cave } \\
(\mathrm{cpm})\end{array}$ & \\
\hline 186.2 & $235_{U}$ & ---- & $0.29(.08)$ & --- \\
\hline 239.0 & $232 \mathrm{Th}$ & $20.2(1.2)$ & $0.22(.05)$ & $92(34)$ \\
\hline 351.9 & ${ }^{238} . \mathrm{U}$ & $17.7(.4)$ & -- & --- \\
\hline 510.5 & $\beta+$ ann. & $8.5(.5)$ & $0.88(.08)$ & $10(1)$ \\
\hline 582.8 & $232 \mathrm{Th}$ & $8.8(.3)$ & --- & --- \\
\hline 608.9 & ${ }^{238} \mathrm{U}$ & $18.5(.4)$ & $0.25(.04)$ & $74(12)$ \\
\hline 910.6 & $232 \mathrm{Th}$ & $7.0(.3)$ & --- & --- \\
\hline 968.3 & $232 \mathrm{Th}$ & $4.1(2)$ & -- & --- \\
\hline 1119.6 & ${ }^{238} \mathrm{U}$ & $5.1(.2)$ & -- & --- \\
\hline 1237.3 & ${ }^{238} \mathrm{U}$ & $.2 .2(.1)$ & -- & --- \\
\hline 1460.0 & ${ }^{40} \mathrm{~K}$ & $44.7(.4)$ & $0.06(.02)$ & $745(250)$ \\
\hline 1591.9 & $2614 \mathrm{DE}$ & $1.3(.1)$ & $=-\infty$ & $--\dot{-}$ \\
\hline 1728.7 & ${ }^{238} \mathrm{U}$ & $0.97(.08)$ & -- & --- \\
\hline 1763.8 & ${ }^{238} \mathrm{U}$ & $5.0(.1)$ & $0.06(.02)$ & $83(27)$ \\
\hline 2102.9 & 2614SE & $1.1(.1)$ & -- & --- \\
\hline 2203.5 & ${ }^{238} \mathrm{U}$ & $1.3(.1)$ & $-\cdots$ & -- \\
\hline 2614.0 & ${ }^{232} \mathrm{Th}$ & $7.1(.2)$ & $0.02(.01)$ & $355(180)$ \\
\hline
\end{tabular}

Notes: 1. ( ) indicates 10 statistica1 uncertainty.

2. Runs were made for a time of 20,000 seconds.

3. The presence of the peak at $186 \mathrm{keV}$ for the run inside the shield suggesta possihle rontamination. 
Access to the shield is gained through the top, which is made of two halves, each on rollers. The Ge(Li) detector is mounted up through the bottom of the shield and is mechanically isolated from the shield with foam rubber. When a sample changer is added to the system, samples will enter through one of the sides of the shield. In order to limit the possibility of contamination of the shield it has been fitted with a plastic liner.

\section{Background Varlations Due to Radon}

The main contribution to the background within the low background stifeld is from atmospherically borne radon and its daughter activities. At present no provision has been made for eliminating these activities from the volume within the shield. An experiment was run to estimate the maximum error that might be introduced as a result of neglecting back-ground corrections. A series of 36 background counts was taken for 20,000 seconds over three weekends. The maximum background rate from all' sources. recorded during any of these intervals corresponded to $<0.5 . \mathrm{ppm} \mathrm{U}_{3} \mathrm{O}_{8}$.. Accordingly, at this stage of the development, no correction for back-ground will be made. When routine counting of bulk samples. begins, a background correction will be made.

\section{Energy Linearity of the System}

The linearity of the system was determined in two ways: using a ramp pulser; and using gamma lines of well known energy. The ramp pulser (Berkeley Nucleonics Model No. GL3) was used to determine if any local non-linearities existed; none were found and the results are shownin: Figure 2. Overall linearity was established using the prominent $214 \mathrm{~Pb}$ and $214 \mathrm{Bi}$ lines in the uranium decay chain. A 20,000-second count was made using a $500 \mathrm{ppm}$ uranium ore standard. Gamma-ray peak centroids were located using the ORTEC Peak Find software package. A least squares fit of a quadratic function to these data gives the energy calibration equation:

$$
\begin{aligned}
\text { Energy }(\mathrm{keV})= & 2.8195+0.6580(\text { Channel No.) } \\
& +0.0000 \times 10^{-7}\left(\text { Channel No.) }{ }^{2}\right.
\end{aligned}
$$

\section{System Stability}

The stability of the system was determined in two tests. The first test determined the short term stability and consisted of a series of twentysix 8,000-second counts of a thorium standard, run consecutively over a weekend. The second test determined the long term stability and consisted of a series of twenty-two 4,000-second counts of ore samples containing uranium and thorium in varying concentrations. These samples were run at random times during the working day over a period of nine days.. From the results generated during each counting period, the position of the centroid of the $2614.6 \mathrm{keV}$ peak of $208 \mathrm{Tl}$ was recorded. In no case did the centroid position fall more than one-half channel from the mean channel number $(\sim 3975)$ in either test. ${ }^{2}$ The results of these tests are shown graphically in Figures $3 a$ and $3 b$.

2 The slight change in gain between the two tests was the result of a slight modification to the system. 

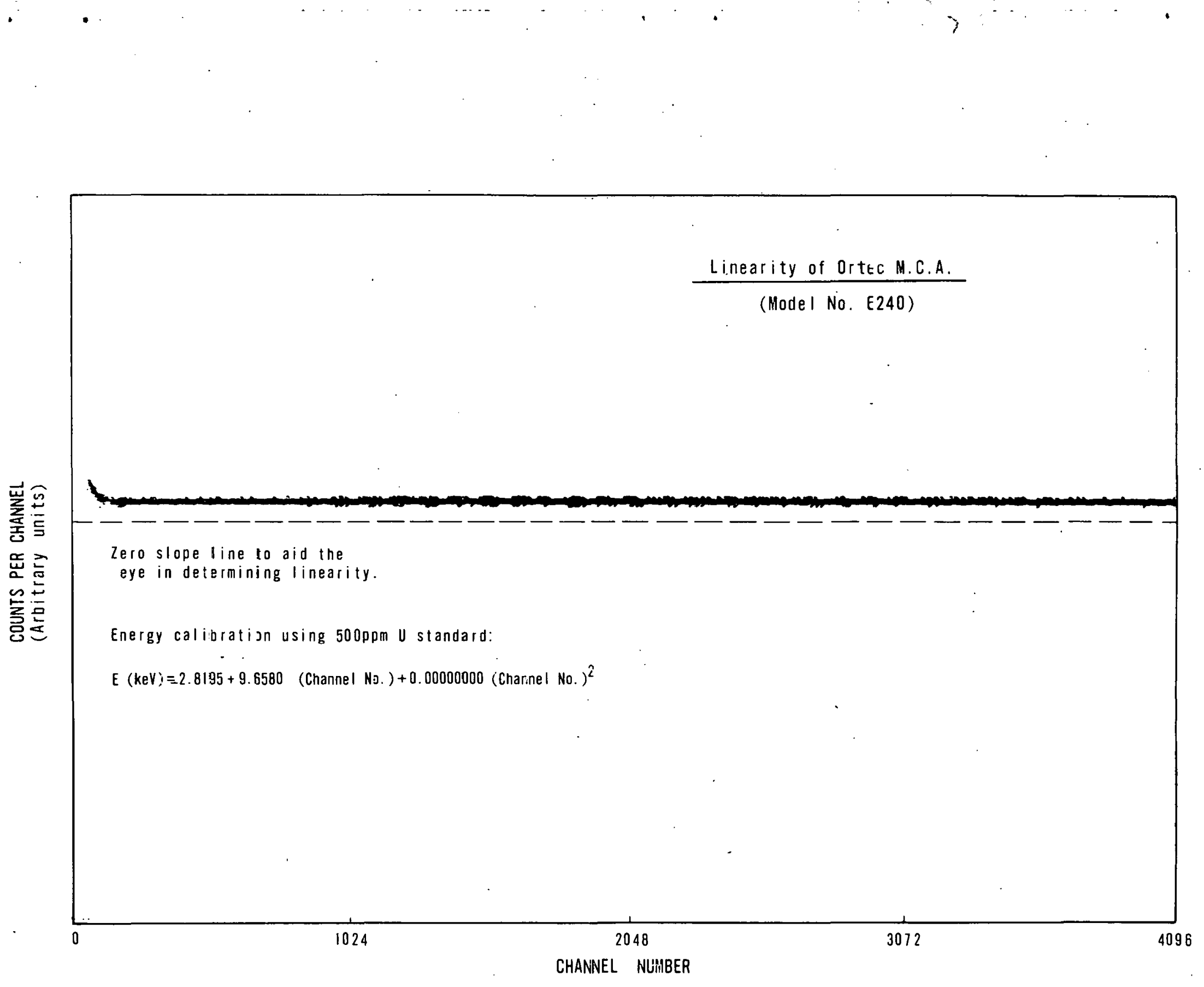

FIGURE 2. Linearity of Ortec MCA Model 6240 Using a Berkeley Nucleonics Ramp Pulser Model GL 3 


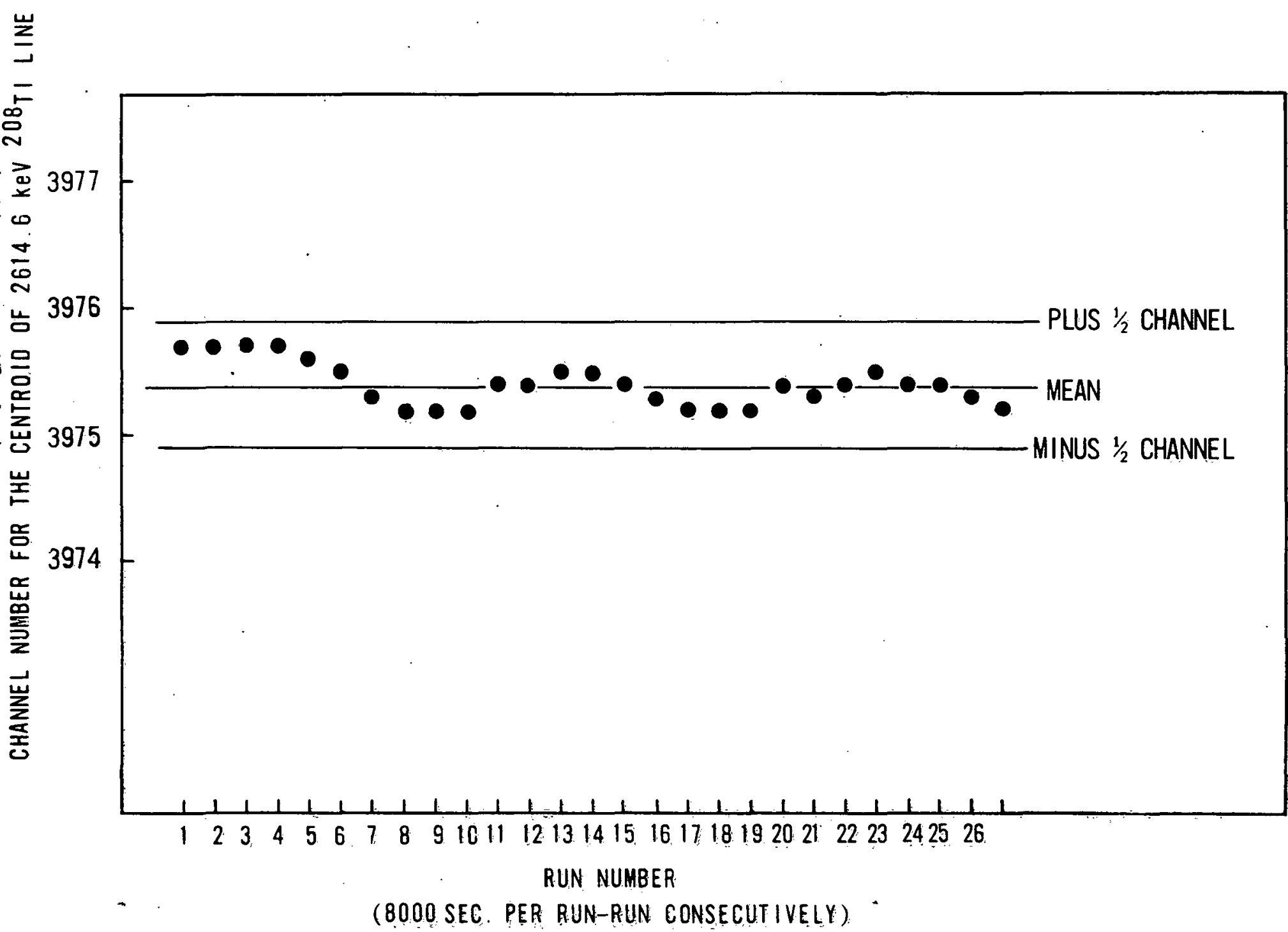

FIGURE 3a. Short Term Stability of the Ortec $6240 \mathrm{MCA}$ 


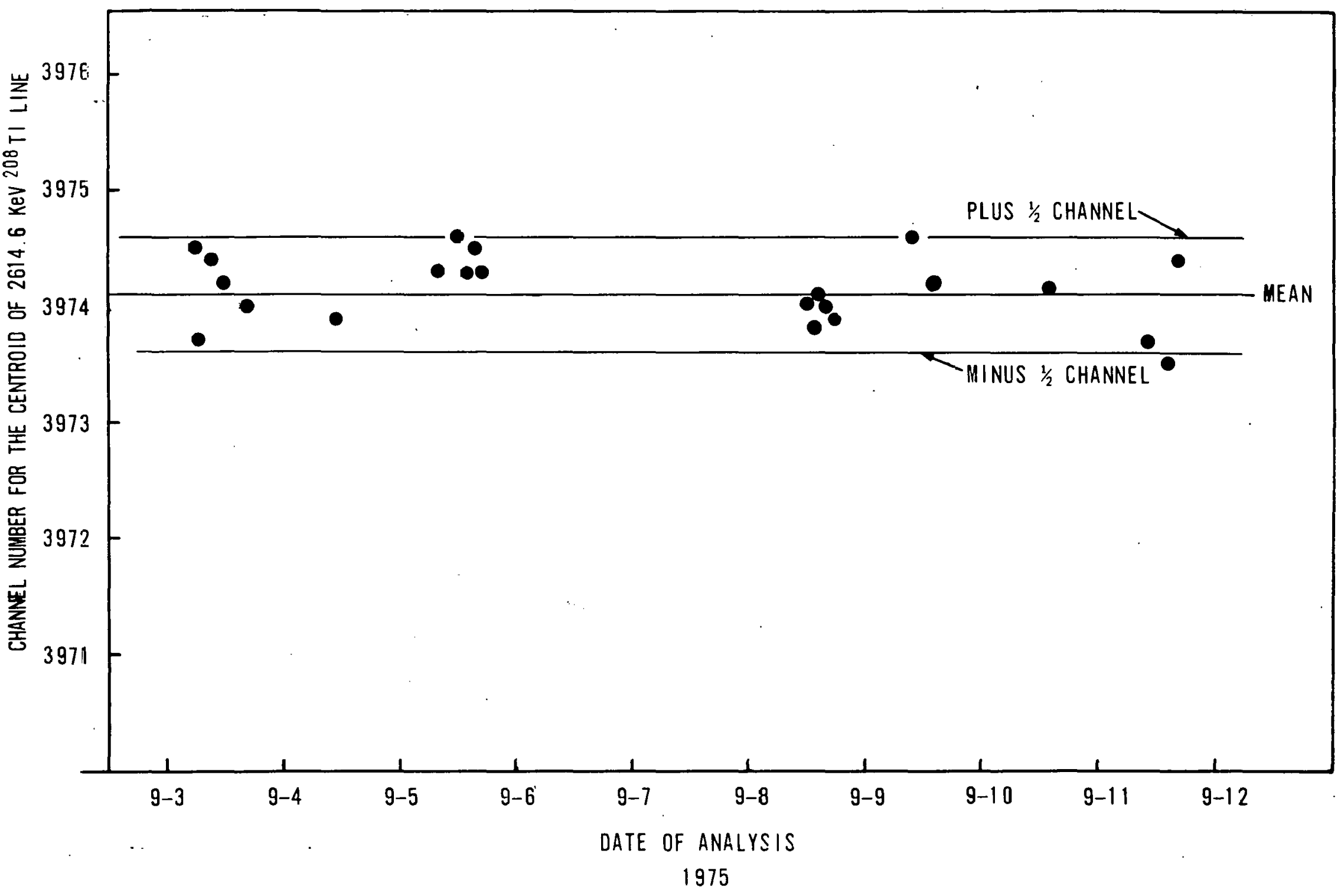

FIGURE 3b. Long Term Stability of the Ortec $6240 \mathrm{MCA}$ 
It is suspected that the periodic nature of the data shown in Figure $3 a$ is a reflection of daily temperature and/or voltage fluctuations.

\section{Absolute Gamma Efficiency}

Absolute gamma efficiency curves were prepared for point sources in two positions and for bulk samples in both large and small cans in contact with the detector. Point source efficiencies were determined for the 1 st and 15 th positions on the source holder prepared for the Ge(Li) detector. These positions correspond to approximate contact with and to a 7-inch separation from the detector along its axis. These efficiencies were determined using absolute counting sources of $241_{\mathrm{Am}}, 133 \mathrm{Ba}, 137 \mathrm{Cs}, 57 \mathrm{Co}, 60_{\mathrm{Co}}, 54 \mathrm{Mn},{ }^{203} \mathrm{Hg}$; $22 \mathrm{Na}$, and $88_{\mathrm{Y}}$ prepared by Amersham, Inc., with strengths of $10 \mu \mathrm{Ci}$ with absolute uncertainties of $2-5$ percent, and sources of $241 \mathrm{Am}, 57 \mathrm{Co},{ }^{137} \mathrm{Cs}$, $54 \mathrm{Mn}$, and ${ }^{22} \mathrm{Na}$ prepared by Isotope Products with strengths of $1 \mu \mathrm{Ci}$ with uncertainties of 2-4 percent. In addition, relative counting sources of ${ }^{56} \mathrm{Co}, 226_{\mathrm{Ra}}$, and ${ }^{228} \mathrm{Th}$ were used to extend the range of the efficiency determination.

Absolute efficiencies for bulk samples along the axis of the detector were determined on contact with the detector in both the large and small can geometry. Can dimensions are 4-1/8-inch diameter $\times$ 2-1/4-inch thick for the large cans and 1-7/8-inch diameter $\times 1 / 2-i n c h$ thick for the small cans. The large and small cans were loaded with $0.051 \pm 0.01$ percent and $1.01 \pm 0.01$ percent uranium, respectively, and allowed to come to radon equilibrium. The source material was supplied by the New Brunswick Laboratory operated by the Energy Research and Development Administration (ERDA) and had a reported radium-to uranium-weight ratio of $3.44 \mathrm{x}$ $10^{-7}$. Absolute counting efficiencies were determined using the absolute gamma intensities reported for the $238 \mathrm{U}$ chain in equilibrium. (Appendix $B$ of this report is a listing of absolute gamma intensities for peaks in the $238 \mathrm{U}, 235 \mathrm{U}$, and $232 \mathrm{Th}$ decay chains.) The result for each of the configurations discussed is presented in Figure 4.

\section{Live Time Clock Errors}

Because of the intent to make quantitative measurements with the Ge(Li) spectrometer, it was necessary to determine the accuracy of live time corrections made by the MCA as a function of count rate. This was done by counting an $88 \mathrm{y}$ source in a fixed geometry and varying the total count. rate using a ${ }^{228} \mathrm{Th}$ source placed at various distances from the detector. In every instance, the gross count rate $>50 \mathrm{keV}$ and the count rate in the $1836 \mathrm{keV}$ peak of ${ }^{88} \mathrm{Y}$ were recorded. These results were plotted and a curve fit to the data. The curve was extrapolated back to zero count rate and set equal to zero percent relative live time clock error at that point, by definition. These results are shown in Figure 5.

In addition to the gross count rate scale, scales for approximate percent uranium as $\mathrm{U}_{3} \mathrm{O}_{8}$ and approximate percent analyzer dead time are included. Five of the data points are shown with error bars for the 2 (95 percent) confidence level to give a feeling for the typical uncertainty in the data points. Because of the importance of live time 




FIGURE 4. Absolute Efficiency of the 16.3 Percent Ge(Li) Spectrometer as a Function of Energy 

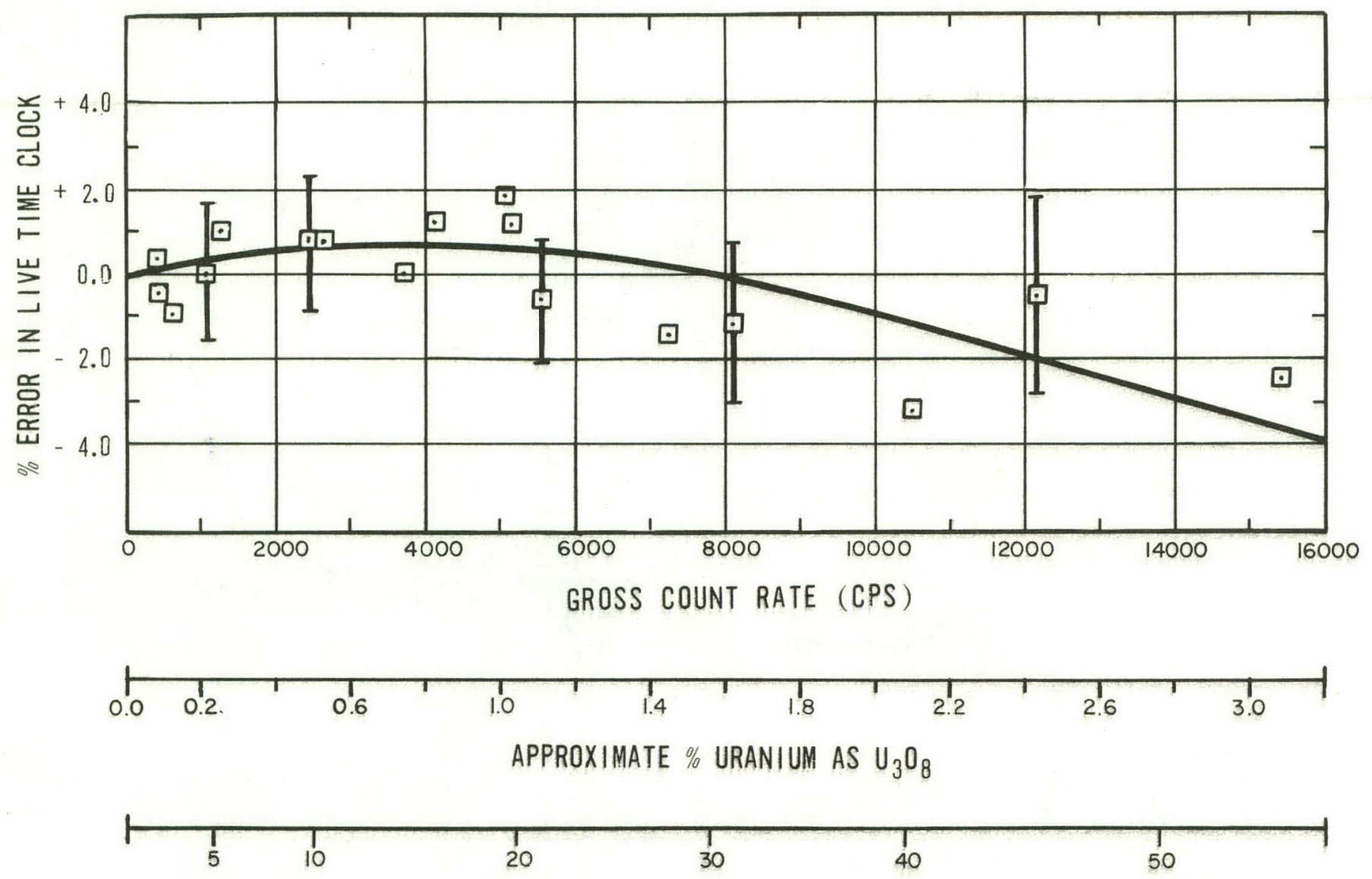

APPROXIMATE \% ANALYZER DEAD TIME

FIGURE 5. Live Time Clock Errors in Ortec $6240 \mathrm{MCA}$ 
corrections, additional data should be collected to reduce the uncertidinty in the shape of the curve if it were not for the following considerations: in this case the live time corrections are relatively smal1; this MCA will soon be replaced with a new system; at high count rates the curve's shape and direction are those expected (based on the MCA's algorithm for live time correction); and at this preliminary stage of the evaluation of the $\mathrm{Ge}(\mathrm{L} i)$ analysis scheme, the ultimate in precision is not necessary. For perspective, it should be pointed out that the maximum live time clock error expected for ore samples in the range from zero to $1.5 \times 10^{4} \mathrm{ppm}$ $\mathrm{U}_{3} \mathrm{O}_{8}$ is only \pm 0.5 percent.

\section{B. Library of Ge(Li) Spectra}

A collection of gamma spectra for bulk samples was recorded using the $\mathrm{Ge}(\mathrm{Li})$ spectrometer. The principal purpose was not to demonstrate the power of this high resolution instrument but rather to serve as an aid in understanding the present $\mathrm{Ge}(\mathrm{Li})$ analysis scheme and to help in the identification of gamma transitions observed during routine analysis.

The first two spectra (equilibrium uranium ore shown in Figure 6 and radium-rich uranium ore shown in Figure 7) are particularly significant. An examination of these two spectra will reveal almost no difference, yet the first is in equilibrium and by definition has a fractional disequilibrium coefficient ${ }^{3}$ of 1.00 while the second is grossly out of equilibrium and has a fractional disequilibrium coefficient of $7.6 \mathrm{x}$ $10^{-3}$. The reason for this is that almost all the peaks present in either spectrum result from the decay of nuclei below radium in the decay chain, primarily $214 \mathrm{~Pb}$ and $214 \mathrm{Bi}$, and therefore cannot be used to indicate the presence of uranium. Figure 10 offers a comparison of the low-energy portions of these spectra. It is this low-energy region where the differences are most noticeable. For example, the 63 and $93 \mathrm{keV}$ peaks from the decay of ${ }^{234} \mathrm{Th}(238 \mathrm{U}$ chain) and the 143,163 and $205 \mathrm{keV}$ peaks from the decay of $235 \mathrm{U}$ are absent in the radium rich, or depleted uranium, spectrum. Also, the $186 \mathrm{keV}$ peak is reduced relative to the $214 \mathrm{~Pb}$ peaks due to the absence of its $235 \mathrm{U}$ component. The third spectrum, radium depleted uranium ore shown in Figure 8 , has a frartinnal disequilibrium coefficient of $>10^{3}$ and exhibits a marked difference from the equilibrium uranium spectrum due to the complete absence of the normally prominent $214 \mathrm{Bi}$ lines.

Spectra of equilibrium thorium ore and potassium as $\mathrm{K}_{2} \mathrm{CO}_{3}$ shown in Figures 9 and 11 respectively, were included to complete the KUT picture. Figure 10 is a presentation of the low-energy portions of Figures 6 through 9 and is the portion of the spectrum in which the greatest differences can be seen.

\footnotetext{
3 Fractional disequilibrium coefficient is defined here to be the ratio of actual $\mathrm{CU}_{3} \mathrm{O}_{8}$ to radiometrically determined $\mathrm{gU}_{3} \mathrm{O}_{8}$ based on the $1765 \mathrm{keV}$ line of $214 \mathrm{Bi}$. See Appendix $\mathrm{C}$ for definitions of the several $\mathrm{U}_{3} \mathrm{O}_{8}$ prefixes.
} 


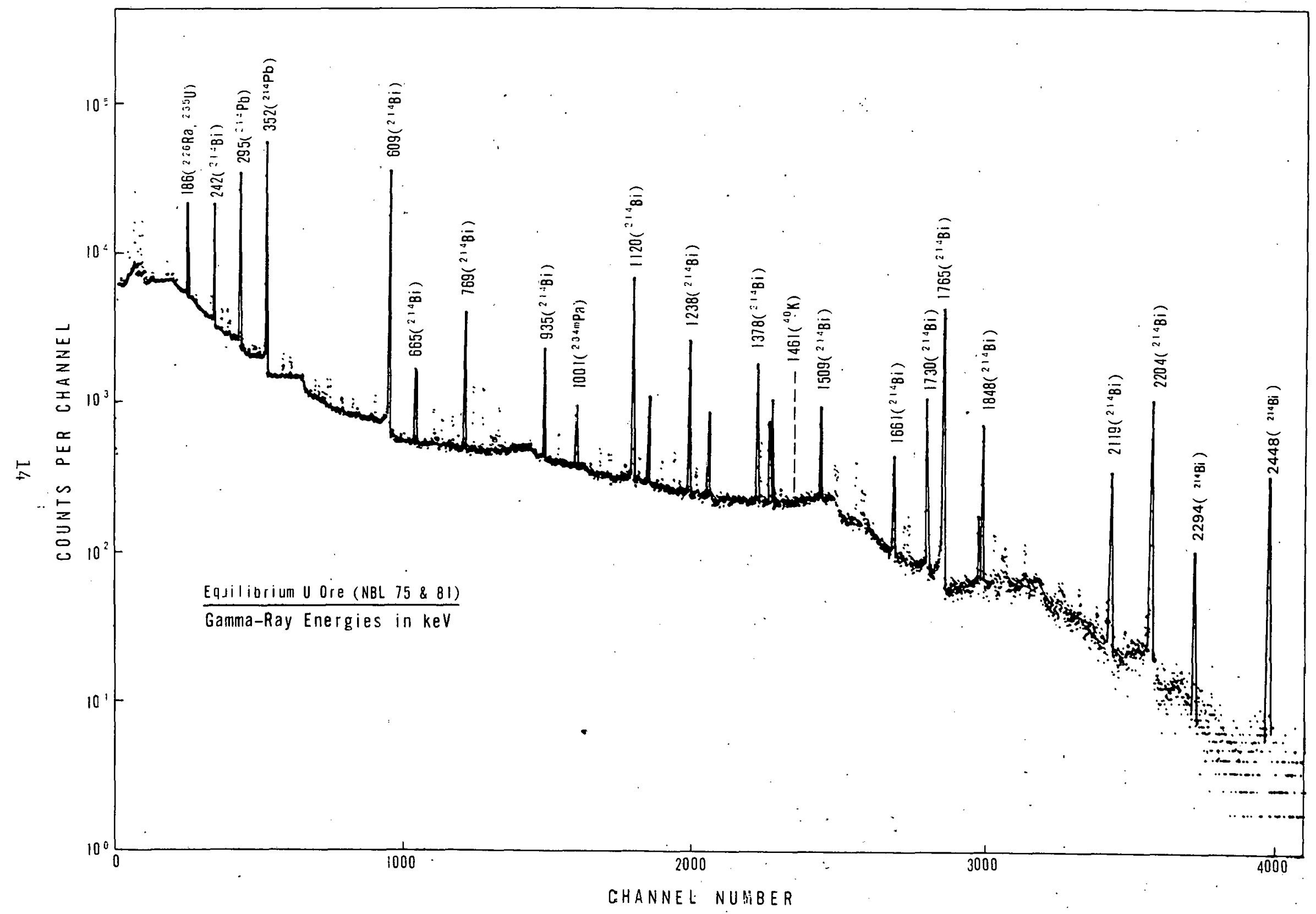

FIGURE 6. Ge(Li) Spectrum of Equilibrium Uranium Ore 


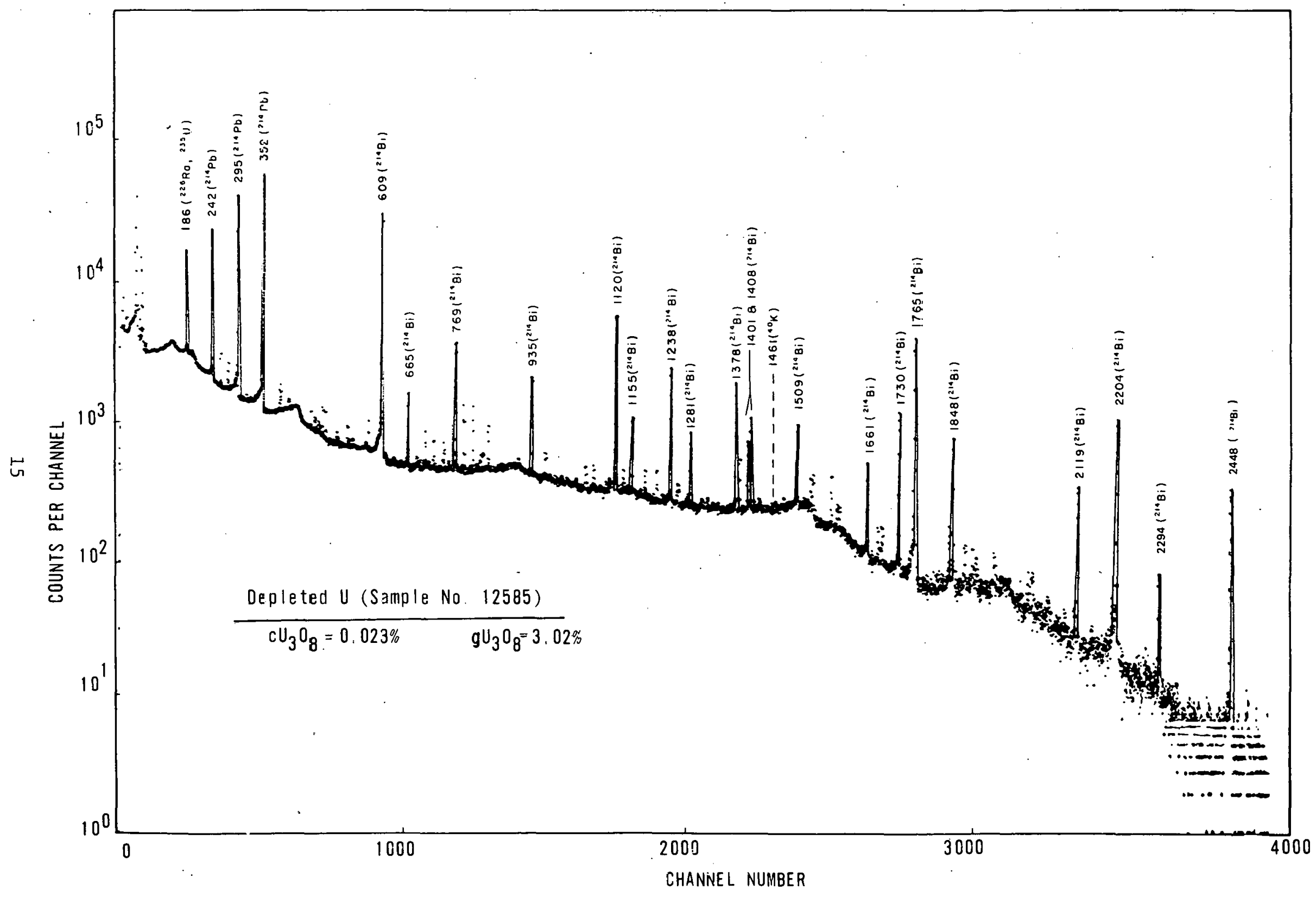

FIGURE 7. Ge(Li) Spectrum of Radium Rich (Depleted Uranium) Uranium 0 ze Sample 


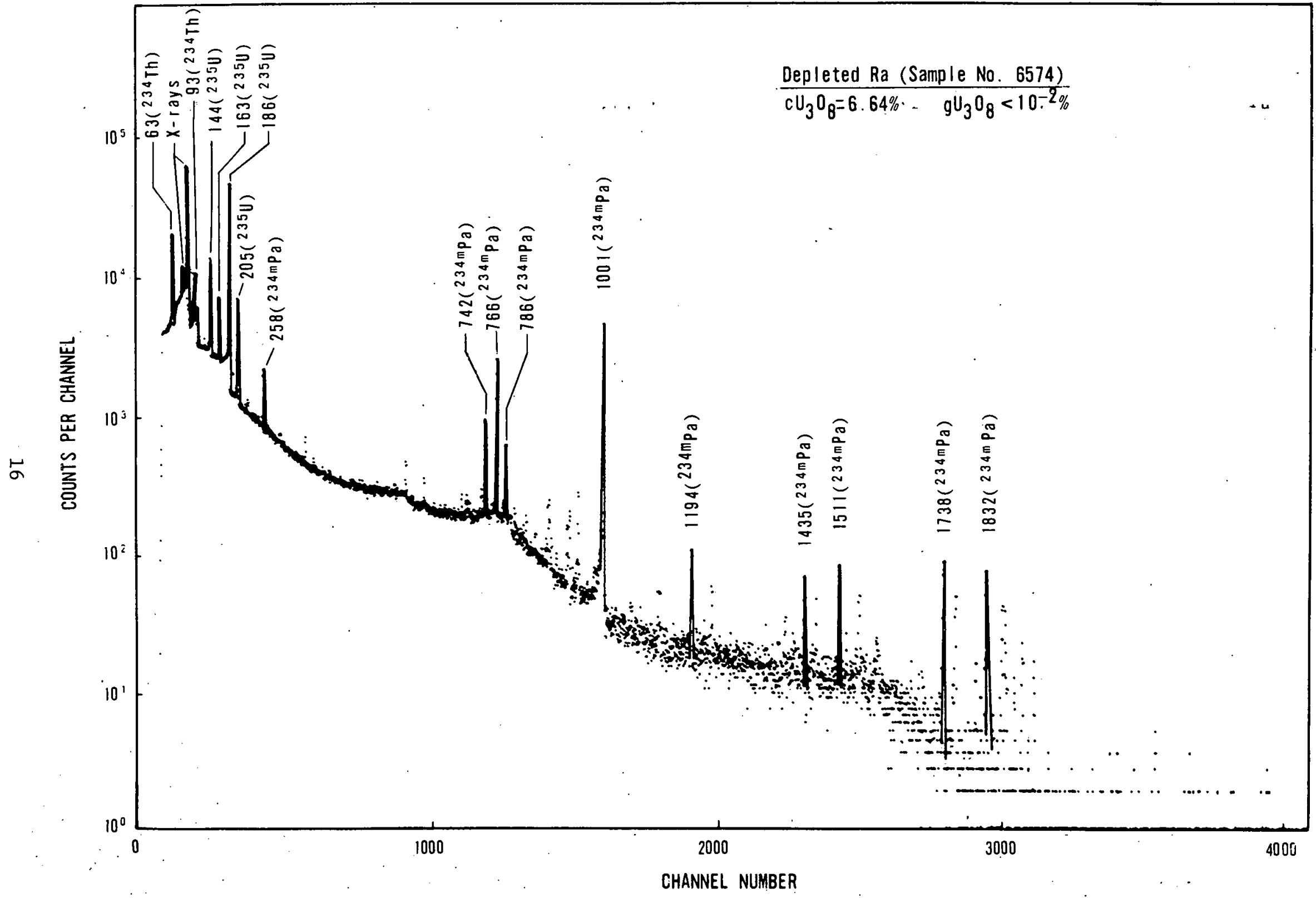

FIGURE 8. Ge(Li) Spectrum of Radium Depleted Uranium Ore Sample 


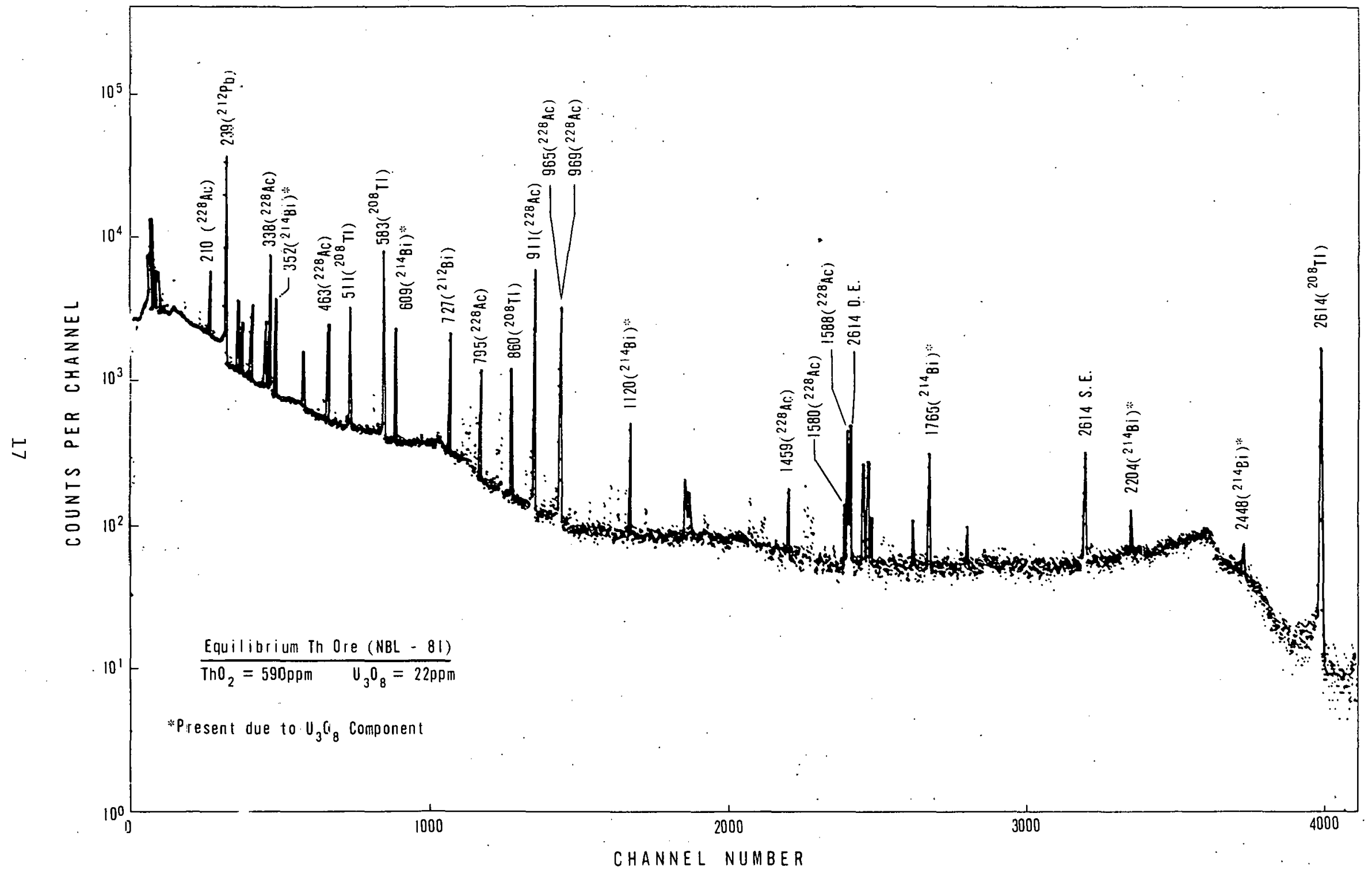

FIGURE 9. Ge(Li) SFectrum of Equilibrium Thorium Jre Sample 
LOG OF COUNTS (ARBITRARY UNITS)

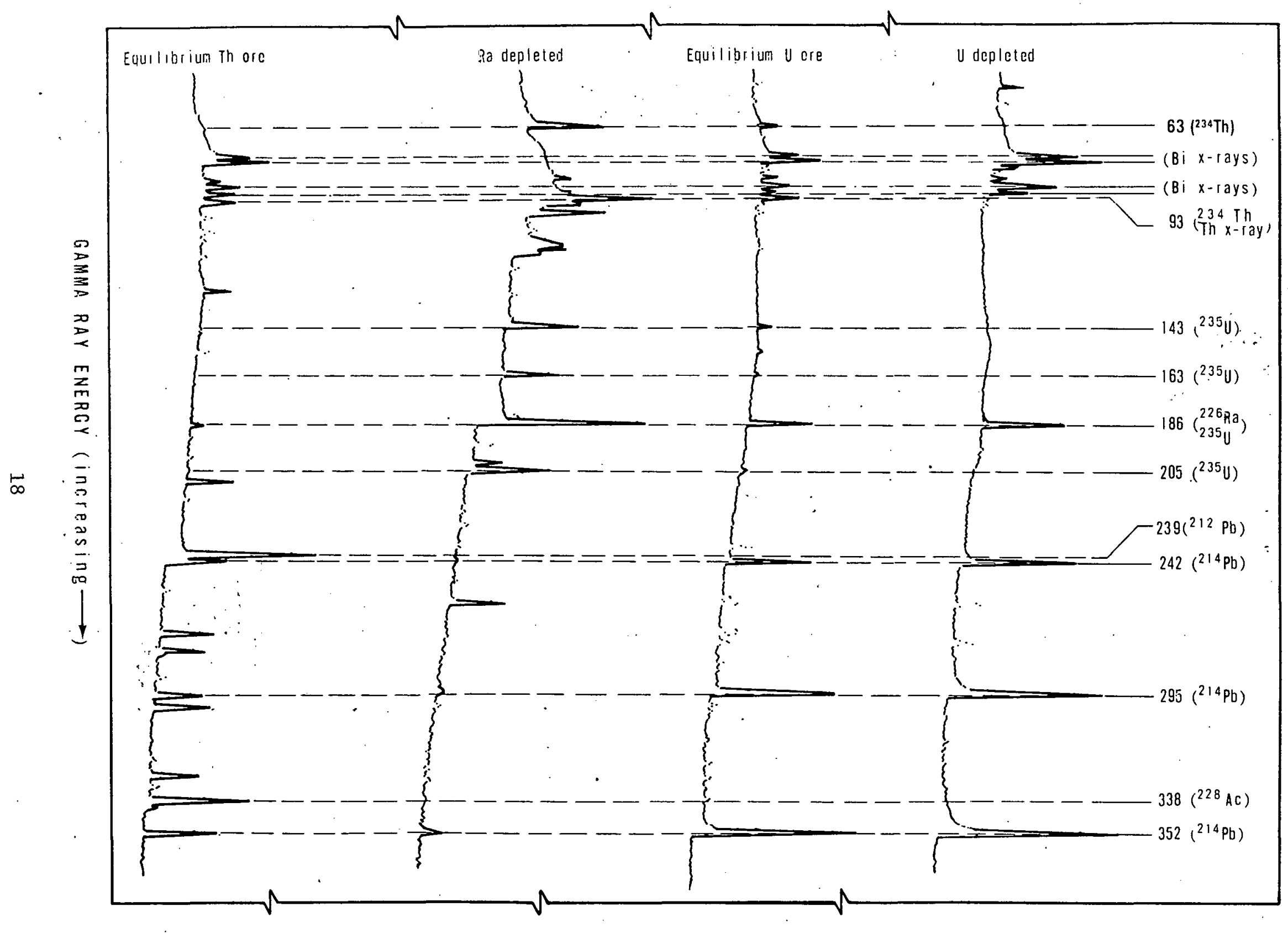

FIGURE 10. Comparison of Jow Energy Portions of Figures 6 through 9 


$$
\leq 4
$$




\section{C. $\mathrm{Ge}(\mathrm{Li})$ Scheme for the "Near Term"}

\section{Analysis Scheme Description}

The first phase of the BFEC Ge(Li) spectrometer project 4 included the development of a preliminary "near term" analysis scheme for computing, among other things, the direct uranium content of bulk samples. As with the NaI(T1) KUT system, it remains necessary to allow canned bulk samples to come to radon equilibrium ${ }^{5}$ (> 20 days). However, improved precision and a direct uranium determination will result from the $G e(L i)$ analysis scheme.

Conventional KUT concentrations will be calculated using the equations below:

$$
\begin{aligned}
& \% \mathrm{~K}=\frac{\mathrm{S}_{\mathrm{K}} \cdot\left[\mathrm{R}_{1461}-(0.0423) \mathrm{R}_{2614}\right]}{\mathrm{W}} \\
& \text { ppm } \mathrm{gU}_{3} \mathrm{O}_{8}=\frac{\mathrm{S}_{\mathrm{gU}_{3} \mathrm{O}_{8}{ }^{\mathrm{R}} 1764}^{\mathrm{W}}}{\mathrm{ppm} \mathrm{ThO}_{2}=\frac{\mathrm{S}_{\mathrm{ThO}_{2} \mathrm{R}_{2614}}}{\mathrm{~W}}}
\end{aligned}
$$

where,

$S=$ (Concentration) (Weight/Count Rate) for a standard sample,

$R=$ Count rate of the signature peak (1461, 1764, $2614 \mathrm{keV})$, 11ve time corrected with Compton background and background contributions to the peaks from sources within the shield subtracted,

$\dot{\mathrm{W}}=$ Sample weight.

The fraction 0.0423 of the $2614 \mathrm{keV}$ intensity from $208 \mathrm{~T} 1$ must be subtracted from the potassium signature at $1461 \mathrm{keV}$ to correct for an interfering thorium series peak at $1459 \mathrm{keV} .6$

In effect, the improved precision in these concentrations results from an elimination of interferences from other peaks that would have fallen in the NaI (Tl) KUT windows and from the ability to eliminate the Compton background by subtraction. See Appendix A for a more complete discussion of these points.

\footnotetext{
${ }^{4}$ K. L. Kosanke, R\&D Project No. 5001, "Sample Analysis Using a Ge(Li) Detector," Sept., 1975.

${ }^{5}$ If the sample is counted twice (e.g. one and three days after canning) it is not necessary to wait for equilibrium and in addition, a relative emanation coefficient can be found for the sample.

${ }^{6}$ Private communication from R. Murri, Bendix Field Engineering Corporation.
} 
The direct $\mathrm{U}_{3} \mathrm{O}_{8}$ determination is based on the calculation of the fractional disequilibrium for the sample, defined earlier in this report as the ratio $\mathrm{U}_{3} \mathrm{O}_{8} / \mathrm{gU}_{3} \mathrm{O}_{8}$. Accordingly,

$$
\text { Concentration } \begin{aligned}
\mathrm{U}_{3} \mathrm{O}_{8}= & \text { (Fractional disequilibrium) } \\
& \left.\mathrm{X} \text { (Concentration } \mathrm{gU}_{3} \mathrm{O}_{8}\right) .
\end{aligned}
$$

The calculation of the fractional disequilibrium is based on the intensity of $186 \mathrm{keV}$ peak ${ }^{7}, R_{186^{\circ}}$. Because of its rather low energy it is necessary to correct the observed intensity for self-absorption in the sample. This is done by first plotting as a function of energy the observed count rates in the 2428,295 , and $352 \mathrm{keV}$ peaks from $214 \mathrm{~Pb}$ in the sample, each divided by their count rate in the uranium standard sample.

$$
A_{E}=\text { Sample } R_{E} / \text { Standard } R_{E}
$$

Next, these three points are fit to a straight line using a least squares technique that weights the points $1: 2: 3$ for the 242,295 , and 352 ratios, respectively. These weight factors approximate the statistical confidence in their relative count rates. It is assumed that a straight line closely approximates the self-absorption curve over this limited energy span, particularly when only three points of limited statistical precison are used. The $A_{E}$ curve is then extrapolated back to $186 \mathrm{keV}$ and the value of $A_{186}$ is read from the graph. Additional studies indicate that the precision of the self-absorption correction improves if a quadratic fit is performed to these three points along with two additional points from the 609 and $1120 \mathrm{keV}$ intensities of $214^{\mathrm{Bi}}$. Finally, the self-absorption corrected count rate of the $186 \mathrm{keV}$ peak, normalized to the uranium standard concentration, is found by dividing the observed peak count rate by $\mathrm{A}_{186^{\circ}}$

$$
\text { Self-absorption corrected } \mathrm{R}_{186}=\text { Sample } \mathrm{R}_{186} / \mathrm{A}_{186}
$$

As mentioned in an earlier note the $186 \mathrm{keV}$ peak can contain a component from $228 \mathrm{Ac}$ in the $232 \mathrm{Th}$ decay chain. This component is subtracted from the 186 peak using the observed count rate for the $239 \mathrm{keV}$ peak of $212 \mathrm{~Pb}$, also in the $232 \mathrm{Th}$ chain.

$$
\begin{aligned}
& \text { Thorium corrected } \mathrm{R}_{186}^{-}=\left(\text {Self-absorption corrected } \mathrm{R}_{136}\right) \\
&-\left(\mathrm{R}_{186} \text { from }{ }^{228} \mathrm{AC}\right) \\
& \mathrm{R}_{186} \text { from } 228{ }_{\mathrm{AC}}=\left(\text { Sample } \mathrm{R}_{239} / \mathrm{A}_{239}\right)\left(2.4 \times 10^{-3}\right)
\end{aligned}
$$

and,

$2.4 \times 10^{-3}=0.105 / 44.6=$ Absolute $\mathrm{I}_{186}$ from ${ }^{228} \mathrm{Ac}$ /Absolute $\mathrm{I}_{239}$ from $212 \mathrm{~Pb}$

${ }^{7}$ Contributions to the $186 \mathrm{keV}$ peak come from up to 10 transitions in the $235 \mathrm{U}, 238 \mathrm{U}$, and ${ }^{232} \mathrm{Th}$ decay chains. The major components are from $235_{\mathrm{U}}, 226_{\mathrm{Ra}}$, and $228 \mathrm{Ac}$ with absolute intensities $\left(\mathrm{I}_{\mathrm{E}}\right.$ ) in their decay chains of 56 percent, 3.5 percent, and 0.105 percent, respectively.

${ }^{8}$ It is necessary to correct the $242 \mathrm{keV}$ peak in the sample spectrum for a contribution from $224 \mathrm{Ra}$ in the ${ }^{232} \mathrm{Th}$ decay chain. This is.done by subtracting from the $242 \mathrm{keV}$ peak, 0.0830 times the count rate of the 239

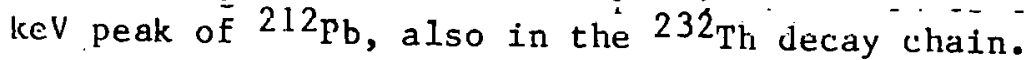


Note, $I_{E}$ is an intensity taken from a decay scheme. Any difference in self-absorption or detection efficiency between 186 and $239 \mathrm{keV}$ is assumed negligibly small.

This thorium corrected 186 peak count rate still contains components fromitransitions in the decay of both ${ }^{226} \mathrm{Ra}$ and $235 \mathrm{U}$. Because the sample has been held long enough for members in the chain below ${ }^{226} 6_{R a}$ to come into equilibrium, it is a simple matter to subtract the ${ }^{226} \mathrm{Ra}$ component from the $186 \mathrm{keV}$ peak count rate.

$$
\begin{aligned}
\text { Radium corrected } R_{186}= & \left(\text { Thorium corrected } R_{186}\right) \\
& -\left(R_{186} \text { from } 226_{R a}\right),
\end{aligned}
$$

where

$$
\begin{aligned}
& \mathrm{R}_{186} \text { from } 226_{\mathrm{Ra}}=\text { (Uranium standard } \mathrm{R}_{186} \text { ) } \mathrm{X} \\
& \text { (Fraction of } 186 \text { events from }{ }^{226} \mathrm{Ra} \text { in the standard), } \\
& \text { Uranium standard } \mathrm{R}_{186}=5.02 \mathrm{cps} \text {, } \\
& \text { Fraction of events from } 226_{\mathrm{Ra}}= \\
& \frac{\text { (Absolute } \left.I_{186} \text { from }{ }^{226}{ }_{R a}\right)}{\text { (Absolute } \left.I_{186} \text { from }{ }^{226} \mathrm{Ra}\right)+\left(\text { Effective } \mathrm{I}_{186} \text { from }{ }^{235} \mathrm{U}\right)} \\
& \text { Absolute } I_{186} \text { from } 226_{\mathrm{Ra}}=3.9 \% \text {, } \\
& \text { Effective } \mathrm{I}_{186} \text { from } 235_{\mathrm{U}}=\text { (Absolute } \mathrm{I}_{186} \text { from } 235_{\mathrm{U}} \text { ) } \\
& \mathrm{X} \text { (Ratio of decay rates of } 235 \mathrm{U}:{ }^{238} \mathrm{U} \text { ), } \\
& \text { Ratio of decay rates of }{ }^{235} \mathrm{Jv}:{ }^{238} \mathrm{U}=\frac{\mathrm{N}_{235}{ }^{\prime} \lambda_{235}}{\mathrm{~N}_{238} \lambda_{238}}
\end{aligned}
$$

where

$$
\begin{aligned}
\mathrm{N}_{235} / \mathrm{N}_{238}=\text { Abundance ratio of } 235_{\mathrm{U}}: 238_{\mathrm{U}} \\
=0.72 / 99.3 \text {, assuming natural abundances }
\end{aligned}
$$

and

$$
\begin{aligned}
\lambda_{235^{/ \lambda}} 238 & =\text { Ratio of decay constants }{ }^{235} \mathrm{U}:{ }^{238} \mathrm{U} \\
& =4.5 \times 10^{+9} / 7.1 \times 10^{+8}
\end{aligned}
$$

By substitution equation (10) becomes

$$
\text { Éffective } \mathrm{I}_{186} \text { from } 235_{\mathrm{U}}=2.5 \%
$$

and equation (9) becomes

$$
\text { Radium corrected } R_{186}=\text { (Thorium corrected } R_{186} \text { ) }-3.06 \mathrm{cps} \text {. }
$$


The radium corrected 186 count rate is just the count rate resulting from $235 \mathrm{U}$ in the sample, normalized to the uranium standard concentration. Then, assuming a constant $235 \mathrm{U} / 238 \mathrm{U}$ ratio, the fractional disequilibrium coefficient will equal the radium corrected 186 count rate divided by the expected 186 count rate from $235_{U} \cdot$

$$
\text { Fractional disequilibrium }=\frac{\left(\text { Radium corrected } R_{186}\right)}{\left(\text { Expected } R_{186} \text { from } 235_{U}\right)}
$$

where

Expected $R_{186}$ from $235_{U}=$ (Uranium standard $R_{186}$ ) $X$

(Fraction of $186 \mathrm{keV}$ events from $235_{\mathrm{U}}$ in the standard) $=1.96 \mathrm{cps}$.

By substitution equation ( 4 ) becomes

Concentration ${ }^{9} \mathrm{rU}_{3} \mathrm{O}_{8}=$ (Radium corrected $\mathrm{R}_{186} \div 1.96 \mathrm{cps}$ )

$\mathrm{X}$ (Concentration $\mathrm{gU}_{3} \mathrm{O}_{8}$ ).

\section{Example Using Analysis Scheme}

Sample number 125050 weighing 609 grams was counted for 4,000 seconds and spectral peak areas determined using the ORTEC "Peak Find" program. The results for the peaks used in this analysis scheme are listed in the table below.

Peak Energy

$186 \mathrm{keV}$
$239 \mathrm{keV}$
$242 \mathrm{keV}$
$295 \mathrm{keV}$
$352 \mathrm{keV}$
$1461 \mathrm{keV}$
$1764 \mathrm{keV}$
$2614 \mathrm{keV}$
Peak Intensity

$\begin{array}{ll}2.02 & \text { cps } \\ 0.19 & \text { cps } \\ 0.72 & \text { cps } \\ 1.56 & \text { cps } \\ 2.58 & \text { cps } \\ 0.166 & \text { cps } \\ 0.279 & \text { cps } \\ 0.0102 & \text { cps }\end{array}$

First, using equations 1 through 3 from the previous section, concentrations of $\mathrm{K}, \mathrm{gU}_{3} \mathrm{O}_{8}$, and $\mathrm{ThO}_{2}$ are calculated.

$$
\% \mathrm{~K}=\frac{\mathrm{S}_{\mathrm{K}} \mathrm{R}_{1461}}{\mathrm{~W}}
$$

where $S_{K}=$ (concentration) $x$ weight/count rate) for the potassium standard and was empirically found to equal $8.50 \times 10^{3}$

percent $\cdot$ grams $\cdot(\mathrm{cps})^{-1}$.

\footnotetext{
${ }^{9}$ Here $\mathrm{rU}_{3} \mathrm{O}_{8}$ is meant to express $\mathrm{U}_{3} \mathrm{O}_{8}$ concentrations as determined using the $186 \mathrm{keV}$ peak from 235U. See Appendix C for a complete listing of $\mathrm{U}_{3} \mathrm{O}_{8}$ prefixes and definitions.
} 
By substitution,

$$
\% \mathrm{~K}=\frac{\left(8.50 \times 10^{3}\right)(0.166)}{609}=2.32 \%
$$

The uncertanity in potassium concentration is reported as twice the statistical uncertanity in the $1461 \mathrm{keV}$ peak area.

$$
\begin{aligned}
\text { Uncertainty in } \mathrm{K} & =2(1461 \text { uncertainty) ( } \mathrm{K} \text { concentration) } \\
& =2(0.045)(2.32 \%)=0.21 \%
\end{aligned}
$$

The potassium concentration was reported as $2.3 \pm 0.2$ percent $K$. Similarly, for $\mathrm{gU}_{3} \mathrm{O}_{8}$ and $\mathrm{ThO}_{2}$, concentrations were reported as $96 \pm 6 \mathrm{ppm} \mathrm{gU}_{3} \mathrm{O}_{8}$ and $8 \pm 3 \mathrm{ppm} \mathrm{ThO}_{2}$.

The determination of $\mathrm{rU}_{3} \mathrm{O}_{8}$ based on $235_{\mathrm{U}}$ gamma transitions is more complicated and begins with establishing the sample self-absorption in the region of the $186 \mathrm{keV}$ transition. It is this peak that is used for the determination of the sample's fractional disequilibrium. As indicated in the previous section, before the sample's self-absorption can be found using the 242,245, and $352 \mathrm{keV}$ peaks, the $242 \mathrm{keV}$ peak must be corrrected for a ${ }^{224} \mathrm{Ra}$ component:

$$
\begin{aligned}
\text { corrected } \mathrm{R}_{242}= & \mathrm{R}_{242}-\left(0.083 \mathrm{R}_{239}\right) \mathrm{cps} \\
& =0.72-(0.017) \mathrm{cps} \\
& =0.70 \mathrm{cps} .
\end{aligned}
$$

\begin{tabular}{|c|c|c|c|c|}
\hline $\begin{array}{l}\text { Peak } \\
\text { Energy }\end{array}$ & $\begin{array}{l}\text { Sample } \\
\text { Intensity }\end{array}$ & $\begin{array}{l}\text { Standard } \\
\text { Intensity }\end{array}$ & Ratio & $\begin{array}{l}\text { Weighting } \\
\text { Factor }\end{array}$ \\
\hline (keV) & (cps) & (cps) & KaLIo & \\
\hline
\end{tabular}

Using equation (5), the ratios $\left(A_{E}\right)$ for the 242, 295, and 352 $\mathrm{keV}$ peaks were determined and are:

$\begin{array}{lllll}242 & 0.70 \pm 0.02 & 4.96 \pm 0.02 & 0.141 \pm 0.002 & 1 \\ 295 & 1.56 \pm 0.02 & 10.63 \pm 0.03 & 0.147 \pm 0.002 & 2 \\ 352 & 2.58 \pm 0.03 & 17.82 \pm 0.04 & 0.145 \pm 0.002 & 3\end{array}$

Note, uncertainties are at the $10\left(67^{\prime}\right.$ percent $)$ confidence level.

These data points were then fit to a straight line using a weighted least-squares technique. While this was done numerically it is also shown graphically for illustration in Figure 12.

Before completing the example calculation for $\mathrm{rU}_{3} \mathrm{O}_{8}$ concentration, it will be instructive to discuss the interpretation of the graph in more detail. If the sample had the same self-absorption and the same concentration as the standard, all the $A_{E}$ ratios would equal one, to within statistical limits. In this instance the slope and intercept should be nearly zero and one, respectively. If the sample had the same self- 


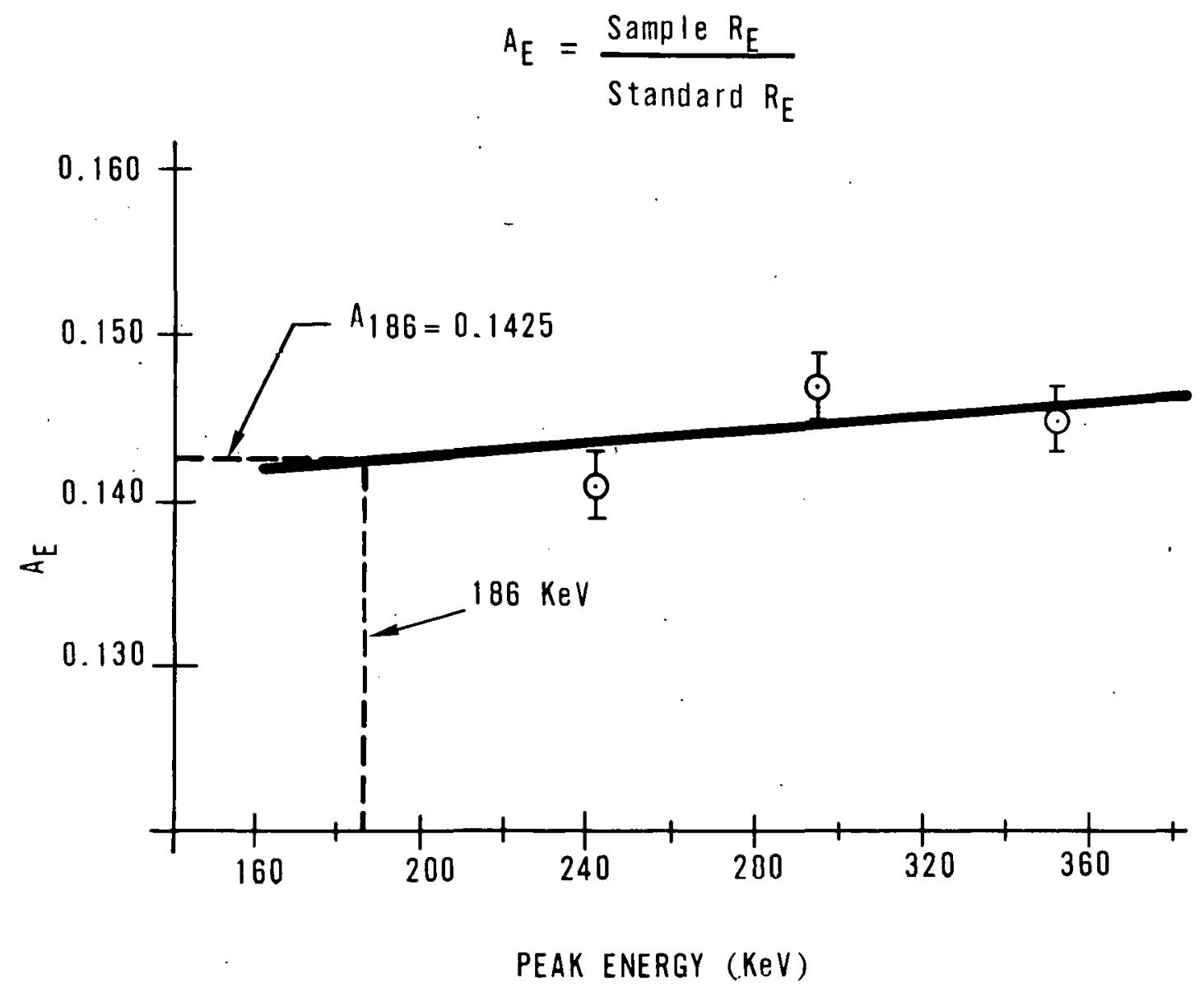

Calculated:

$$
\text { Slope }=1.83 \times 10^{-5}
$$

Intercept $=0.139$

Average deviation $=1.2 \%$

$$
A_{186}=0.1425
$$

FIGURE 12. Graphic Presentation of Numerically Generated Weighted Least Squares Fit of the Ratios $A_{E}$ 
absorption as the standard, but had either greater or lesser $\mathrm{U}_{3} \mathrm{O}_{8}$ concentration, all the $A_{E}$ ratios would be equal and either greater or less than one, respectively. In the case of Figure 12 the $A_{E}$ ratios are each approximately 0.14 , thus the sample must have about one-sixth the $214 \mathrm{~Pb}$ concentration of the standard. A comparison of $1764 \mathrm{keV}$ peak intensities does indeed suggest a $214 \mathrm{~Pb}$ concentration of $1 / 6.21$ that of the standard. Because of the generally exponential dependence of selfabsorption on gamma energy, if the sample self-absorption is greater or less than the standard it must be expected that the slope of the $A_{E}$ ratios will be positive or negative, respectively. In the case of Figure 12 the curve has a slight positive slope, indicating the sample is slightly more self-absorbing than the standard.

Returning to the example calculation, after the slope and intercept are found, the $A_{186}$ ratio is calculated to be 0.1425 . By substitution into equation ( 6 )

$$
\text { Self-absorption corrected } \mathrm{R}_{186}=\frac{\mathrm{R}_{186}}{\mathrm{~A}_{186}}=\frac{2.02}{0.142} \mathrm{cps}=14.2 \mathrm{cps} \text {. }
$$

This is the count rate that would be expected if the sample were at the standard concentration with the same self-absorption as the standard. The next step is to calculate and subtract the $186 \mathrm{keV}$ component from ${ }^{228} \mathrm{Ac}$ in the ${ }^{232}$ Th decay chain. By substitution into equation ( 8 ),

$$
\begin{aligned}
\mathrm{R}_{186} \text { from }{ }^{228} \mathrm{Ac} & =\frac{\left(\text { Sample } \mathrm{R}_{239}\right)\left(2.4 \times 10^{-3}\right)}{\mathrm{A}_{239}} \\
& =\frac{(0.19)\left(2.4 \times 10^{-3}\right)}{0.143}=3.2 \times 10^{-3} \mathrm{cps} .
\end{aligned}
$$

Thus, ,

Thórium corrected $\mathrm{R}_{186}=\left(14.2-3.2 \times 10^{-3}\right) \mathrm{cps}=14.2 \mathrm{cps}$.

The $186 \mathrm{keV}$ component for ${ }^{228} \mathrm{Ac}$ is negligible. The final correction to" the $186 \mathrm{keV}$ peak is to subtract the equilibrium contribution from $226 \mathrm{Ra}$, which, as found in the last section, is $3.06 \mathrm{cps}$.

Thus,

Radium corrected $R_{186}=(14.2-3.06) c p s=11.1 \mathrm{cps}$

and,

$$
\begin{aligned}
\text { Fractional disequilibrium } & =\frac{\text { Radium corrected } R_{186}}{\text { Expected } R_{186} \text { from }{ }^{235} \mathrm{U}} \\
& =\frac{11.1}{1.96}=5.66
\end{aligned}
$$


Fron equation (4),

$$
\text { Concentration } \begin{aligned}
\mathrm{rU}_{3} \mathrm{O}_{8}= & \begin{aligned}
(\text { Fractional disequilibrium }) \times \\
\text { (Concentration } \left.\mathrm{gU}_{3} \mathrm{O}_{8}\right)
\end{aligned} \\
= & (5.66)(96 \mathrm{ppm})=544 \mathrm{ppm} .
\end{aligned}
$$

A chemical determination of $\mathrm{U}_{3} \mathrm{O}_{8}$ concentration had been made for this sample previously and was reported to be $510 \pm 50 \mathrm{ppm} \mathrm{cU}_{3} \mathrm{O}_{8}$.

\section{Preliminary Results Using Analysis Scheme}

Several of the numerical values used to calculate $\mathrm{rU}_{3} \mathrm{O}_{8}$ concentration were determined empirically at other labs and often contain significant uncertainties. The result could be systematic error in $\mathrm{U}_{3} \mathrm{O}_{8}$ concentration reported when using this scheme and it may be necessary to add a correction factor to equation (12). This factor will be determined empirically through a comparison of radiometrically and chemically determined $\mathrm{U}_{3} \mathrm{O}_{8}$ concentrations.

At this early stage of development of the $\mathrm{Ge}(\mathrm{Li})$ technique, errors reported for percent $\mathrm{K}, \mathrm{ppm} \mathrm{gU}_{3} \mathrm{O}_{8}$, and $\mathrm{ppm} \mathrm{ThO}_{2}$ are twice the statistical values, i.e.

$$
\text { Reported error }=2\left(\mathrm{~Np}+2 \mathrm{~N}_{\mathrm{b}}\right) 1 / 2
$$

where

Np. is the net number of counts in the peak

$\mathrm{Nb}$ is the number of counts in the background under the peak.

While it is known that these error limits are too generous and will be reduced, they should not be lowered to just one times the statistical error because of unresolved uncertainties, such as uncertainties in reported standard concentrations, uncertainties in counting geometries from one can to the next, and uncertainties in self-absorption at even the higher energies used in determining percent $\mathrm{K}$, ppm $\mathrm{gU}_{3} \mathrm{O}_{8}$, and $\mathrm{ppm}$ $\mathrm{ThO}_{2}$ - Similarly, at this early stage of development, it is felt no error limits can be presented for reported $\mathrm{rU}_{3} \mathrm{O}_{8}$ concentration.

Table 3 presents a comparison between chemically and radiometrically determined $\mathrm{U}_{3} \mathrm{O}_{8}$ concentrations for small can samples. Each sample was counted for 4,000 seconds. It should be assumed the same precision would result for the normal large can samples either with one-fourth the uranium concentration or for counting one-fourth the time. 
TABLE 3

Comparison of Chemical and Radiometric $\mathrm{U}_{3} \mathrm{O}_{8}$ Assays. The Radiometric Assay Utilizes the $186 \mathrm{keV}$. Intensity from the Decay of $235 \mathrm{U}$.

\section{$\mathrm{U}_{3} \mathrm{O}_{8}$ Concentration (ppm)}

Sample No.

12281

12282

12283

12284

12285

12286

12287

1.2288

12289

12290
Chemical

590

1400

1000

430

1590

4250

7700

640

1270

2270

4640

Radiometric

D. Conclusions and Recommendations

A high resolution Ge(Li) gamma-ray spectrometer has been installed and made operational for use in routine bulk sample analysis by the BFEC geochemical analysis devartment. The Ge(Li) spectrometer provides bulk sample analyses for potassium, uranium, and thorium that are superior to those: o,btained by the BFEC sodium iodide spectrometer.

The "mear term" analysis scheme perwits a direct assay for uranium that corrects for bulk sample self-absorption effects and is independent of the uranium/radium disequilibrium condition of the sample.

A more complete analysis scheme should be developed that fully utilizes: the gama-ray data provided by the Ge(Li) spectrometer and that more properly accounts; for the sample self-absorption effect. Such a scheme has been d'evised under a BFEC subcontract to Nuclear Environmental Services/SAI. A report describing this; scheme and its: evaluation has been placed on open-fille by/ the DOE/Grand Junction. ${ }^{10}$ This new analysis scheme should be implemented on the BFEC Ge(Li); spectrometer at: the earliest date.

10:J. E. Cline, "Develiopment of New and Improved Data Reduction Techniques: for Radiometric Assay of Bulk Uranium Ore: Samples:", Science Applications Inc., G.JB:X-124.(78), $19777 \%$. 
APPEENDIX A

DESCRIPTION OF GAMMA SPECTROMETRY AS APPLIED TO LABORATORY BULK SAMPLE ANALYSIS

\section{1) General Discussion}

Gamma-ray photons emitted from nuclei undergoing decay have discrete energies characteristic of the nuclear species from which they were emitted. For example, when $235 \mathrm{U}$ nuclei decay, gamma photons with 27 different characteristic energies can be emitted; the most frequent being $185.71 \mathrm{keV}$ photons which are emitted in 56 percent of the decays.

For a bulk sample, some fraction of the gamma photons emitted from decaying nuclei contained in the sample are absorbed in the sample itself and are, in effect, totally lost to an observer of the bulk sample. This is a result of interactions between photons and atomic electrons in which all of the photon's energy is lost to the electron (photoelectric effect). This is an energy dependent phenomenon affecting low-energy photons most strongly and has the effect of changing the energy distribution of photons emanating from the bulk sample. For example, if 100 gamma photons were emitted from decaying nuclei in a sample, 50 of which possessed $100 \mathrm{keV}$ of energy and 50 of which possessed $10 \mathrm{MeV}$ of energy, it is quite possible, considering only the photoelectric effect, that the final distribution of photons might be 5 and 49 for $100 \mathrm{keV}$ and $10 \mathrm{MeV}$, respectively.

An additional fraction of the gamma photons emitted by decaying nuclei do emanate from the bulk sample but no longer have energies characteristic of the nucleus from which they originated. This is a result of interaction with atomic electrons in which only a portion of the energy of the incident photon is lost to the electron (Compton scattering). This also is an energy dependent phenomenon and has the effect of further changing the energy distribution of "characteristic" photons emanating from the bulk sample. Accordingly, gamma photons emanating from a bulk sample can be divided into two categories: first are those which have not Compton scattered within the sample and have energies characteristic of the emitting nuclei, but have an altered energy distribution as a result of photoelectric interaction; second are those which have Compton scattered and have a continuous spectrum of energies from zero to near the maximum energy of the nuclear gamma photons. There is a less important third category of photons, those resulting from positron annihilation following pair production. These have the characteristic energy of $511.01 \mathrm{keV}$ and only occur for gammas with energies $>1022 \mathrm{keV}$.

The question to ask at this point is, can an analysis of the gamma photons cmanating from a bulk sample yield quantitative information on the radioactive components of the sample? The answer is an unqualified yes if we know enough about the bulk sample, and fortunately, only a slightly qualified yes, if we do not. If the sample size, density, approximate spacial distribution of radionuclides, and approximate distribution of atomic numbers for the components of the sample are known, then it is possible to correct for all the distortions of the initial flux of gamma photons emitted from decaying nuclei in the sample. Once the initial gamma flux is reconstructed on paper, it 
is a simple matter to determine quantitatively the radioactive constituents of a sample. The method is essentially one of counting up the number of photons emitted with characteristic energies for each of the nuclei being sought and multiplying by proportionality constants. Fortunately, even though this amount of detailed information about the sample is not generally known, the ranges of values found in practice are not extremely broad. Accordingly, techniques involving the comparison of the gamma flux from a typical (standard) bulk sample and the gamma flux from an unknown sample in the laboratory can be expected to yield results with relatively good precision.

The discussion above was idealized to the extent that no mention was made of the mechanism for detecting the gamma photons emanating from the sample. The ability to quantitatively assay the radioactive components of a bulk sample, knowing the emitted gamma flux, would be of little value if additional uncertainties were introduced in the detection process. Gamma photons undergo the same interactions in the detection process as they did in the bulk sample (photoelectric, Compton, and pair production). The effect of these competing interactions is indeed to distort the observed gamma flux. Fortunately, a great deal is known about the detectors used and this distortion can be corrected either theoretically by calculation or empirically by comparison 'with standard samples of known concentrations. Thus, in practice the answer to the question about the ability to perform quantitative analysis of bulk samples remains only a slightly qualified yes.

It is worth noting further that the accuracy of the assay is improved if only those gamma photons are considered which are detected as still possessing the full energy they had when they were initially emitted from the nucleus (these are the characteristic energies mentioned earlier). These gamma photons will not have interacted in the bulk sample and will have interacted in the detector to deposit their full energy generating photopeaks. With this simpler and more direct transport mechanism it is not necessary to consider a collection of mechanisms which can start with gamma photons with different initial energies, which interact in the hullk sample or detertor to lose a portion of their energy and finally be detected as photons of the same energy. The result of using only photopeak (full energy) intensities in the assay technique is greater precision as a result of fewer uncertainties than those associated with more complicated mechanisms. This theme will be taken up again in Section 3 of this Appendix when mentioning one of the proposed new methods for KUT spectrographic analysis.

\section{2) Description of the NaI(T1) KUT Spectrometer and Analysis Schemes}

The KUT gamma spectrometer presently in use in the Analytical Laboratory is shown as a block diagram in Figure A-1. The gamma detection system employs a NaI(T1) crystal. Pulses from the detector are amplified and presented to the input of a 512 channel analyzer which sorts the pulses according to amplitude (gamma energy). After 2,400 seconds the data stored in the MCA is dumped to DEC $11 / 20$ computer storage. At this point the data is transferred to magnetic tape in order to be processed on the CDC-3100. 


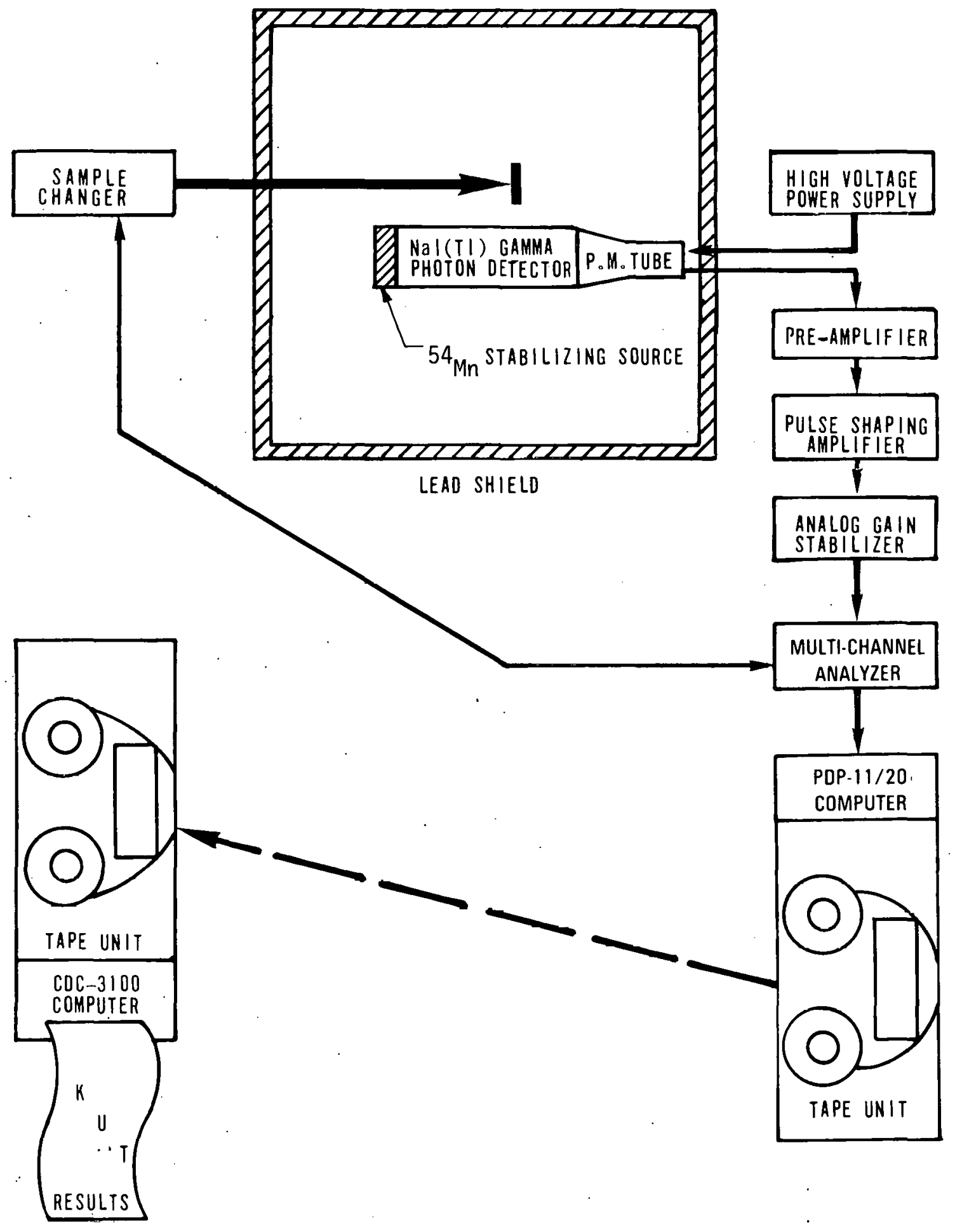

FIGURE A-1. Block Diagram of Geochemical Analytical Laboratory KUT Spectrometer 
'There are three regions (windows) in the energy spectrum that respond to the characteristic gamma photons of potassium, uranium, and thorium.11 These regions are shown in Figure $\mathrm{A}-2$. It is the count rates recorded in

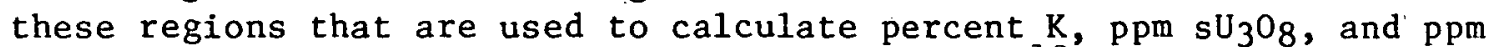
$\mathrm{ThO}_{2}$. These calculations now proceed as follows ${ }^{\mathrm{l} 2}$ :

$$
\begin{aligned}
\operatorname{Th}(\mathrm{ppm}) & =\frac{\mathrm{S}_{\mathrm{th}} \mathrm{R}_{\mathrm{Th}}}{\mathrm{W}} \times 10^{4}, \\
\mathrm{sU}(\mathrm{ppm}) & =\frac{\mathrm{S}_{\mathrm{U}}\left(\mathrm{R}_{\mathrm{U}}-\mathrm{R}_{\mathrm{U}, \mathrm{Th}}\right)}{\mathrm{W}} \times 10^{4}, \\
\% \mathrm{~K} & =\frac{\mathrm{S}_{\mathrm{K}}\left(\mathrm{R}_{\mathrm{K}}-\mathrm{R}_{\mathrm{K}, \mathrm{Th}}-\mathrm{R}_{\mathrm{K}, \mathrm{U}}\right)}{\mathrm{W}}
\end{aligned}
$$

where

$\mathrm{Th}(\mathrm{ppm}), \mathrm{sU}(\mathrm{ppm})$, and $\mathrm{K}(\%)$ are the concentrations of thorium, uranium, and potassium,

$\mathrm{S}_{\mathrm{Th}}$, ' $\mathrm{S}_{\mathrm{U}}$, and $\mathrm{S}_{\mathrm{K}}$ are the calibration coefficients for $\mathrm{Th}, \mathrm{U}$, and $\mathrm{K}$,

$\mathrm{R}^{\mathrm{Th}}{ }^{\prime} \mathrm{R}_{\mathrm{U}}$, and $\mathrm{R}_{\mathrm{K}}$ are the net count rates recorded in the $T h, U$ and $K$ windows.

$R_{U, T h}, R_{K}, T h$, and $R_{K, U}$ are the cross count rates recorded in the $U$ window from $T h$, in the $K$, window from $T h$, and in the $K$ window from $U$, respectively, and are defined below. $W$ is the weight of the sample:

The calibration coefficients are determined from standards:

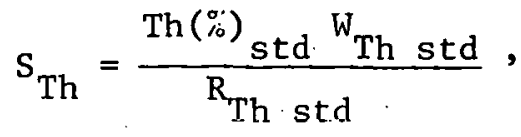

$$
\begin{aligned}
& \mathrm{S}_{\mathrm{U}}=\frac{\mathrm{U( \% )} \text { std } \mathrm{W}_{\mathrm{U} \text { std }}}{\mathrm{R}_{\mathrm{U}} \mathrm{std}}, \\
& \mathrm{S}_{\mathrm{K}}=\frac{\mathrm{K}(\%)_{\text {std }} \mathrm{W}_{\mathrm{K} \text { std }}}{\mathrm{R}_{\mathrm{K}} \mathrm{std}} .
\end{aligned}
$$

11-In the case of uranium and thorium, it is actually gamma radiation from daughters that are detected. The $214_{\mathrm{Bi}} 1765 \mathrm{keV}$ line is used for uranium and the ${ }^{208} \mathrm{Tl} 2614 \mathrm{keV}$ line is used for thorium. The assumption of secular. equilibrium is implicit.

12 Described in "Handbook of Analytical Procedures," RMO-3008, February :6, 1970 . 


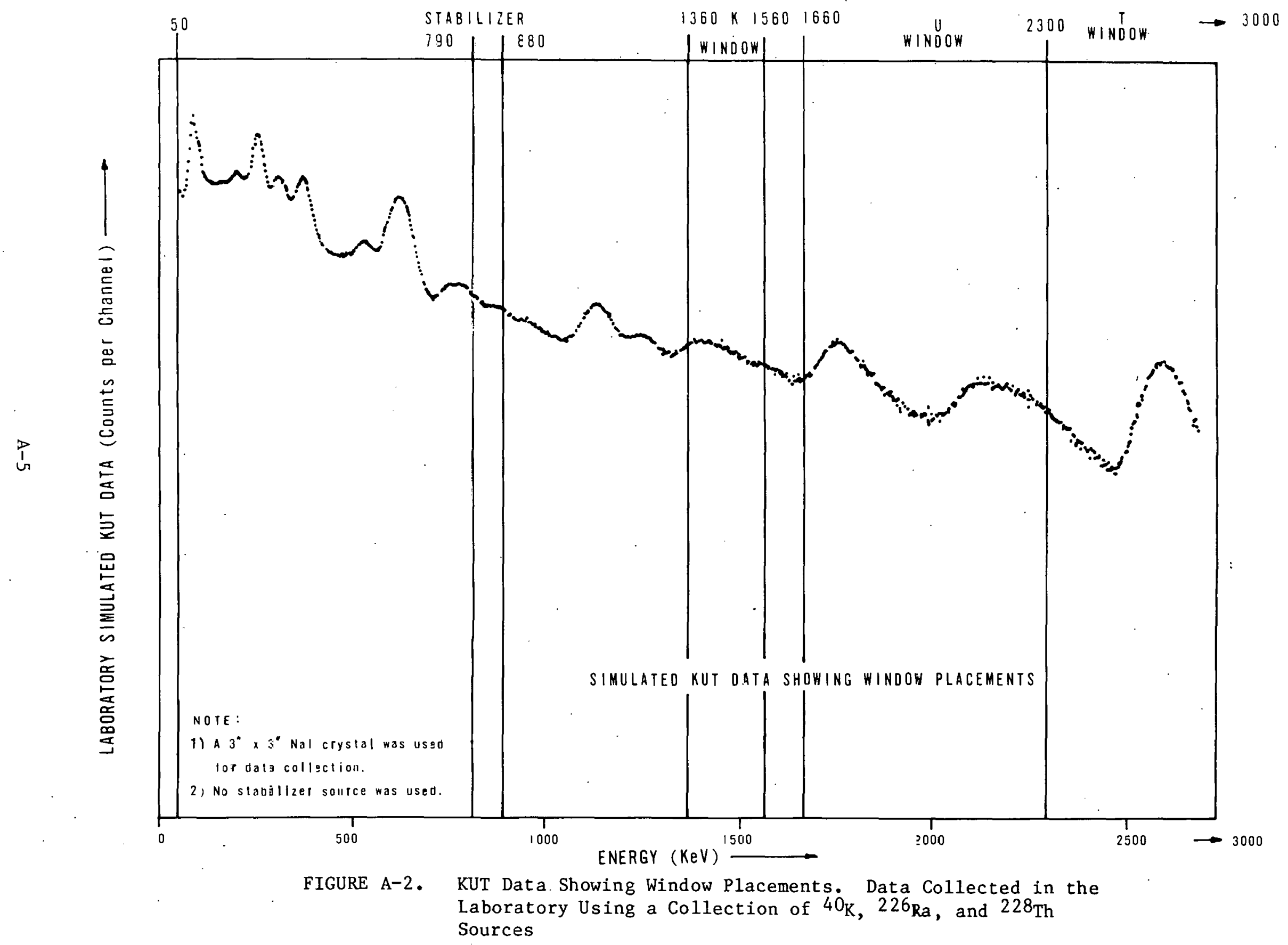




$$
\begin{aligned}
\mathrm{R}_{\mathrm{U}, \mathrm{Th}}=\frac{\mathrm{S}_{\mathrm{Th}} \mathrm{R}_{\mathrm{Th}}}{\mathrm{K}_{\mathrm{U}, \mathrm{Th}}}, \\
\mathrm{R}_{\mathrm{K}, \mathrm{Th}}=\frac{\mathrm{S}_{\mathrm{Th}} \mathrm{R}_{\mathrm{Th}}}{\mathrm{K}_{\mathrm{K}, \mathrm{Th}}}, \\
\mathrm{R}_{\mathrm{K}, \mathrm{U}}=\frac{\mathrm{S}_{U}}{\mathrm{~K}_{\mathrm{K}, U}}\left(\mathrm{R}_{\mathrm{U}}-\mathrm{R}_{\mathrm{U}, \mathrm{Th}}\right),
\end{aligned}
$$

where $\mathrm{K}_{\mathrm{U}}, \mathrm{Th}, \mathrm{K}_{\mathrm{K}, \mathrm{U}}$, and $\mathrm{K}_{\mathrm{K}}, \mathrm{Th}$ are count conversion factors.

The count conversion factors are determined from standards:

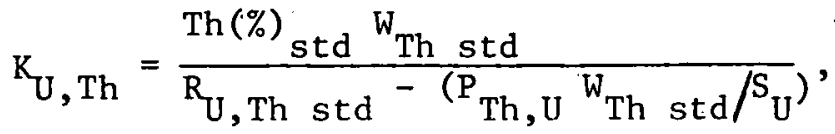

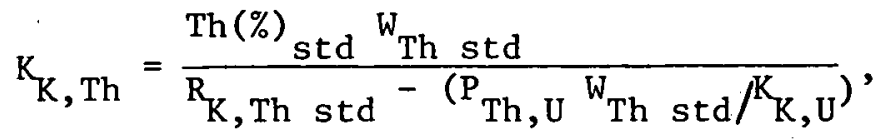

$$
\begin{aligned}
& \mathrm{K}_{\mathrm{K}, \mathrm{U}}=\frac{\mathrm{U}(\%){ }_{\text {std }} \mathrm{W}_{\mathrm{U}} \text { std }}{\mathrm{R}_{\mathrm{K}, \mathrm{U}} \text { std }} \text {, }
\end{aligned}
$$

where $P_{T h, U}$ is the percent $U$ in the Th standard.

These equations are quite involved; yet they still possess the basic deficiency of not correcting for uranium peaks entering partially into the thorium window, as shown in Table A-1. What is needed is a $R_{T h}, \mathrm{U}$ term subtracted from $R_{T h}$ in equation (1). This deficiency has been corrected through the implementation of the analysis program KOSNAI.

The complexity of the preceding equations arises directly from the broad window method used to collect data with the present KUT system. The data recorded in the windows comes from three principal sources (see Table A-1): first is a contribution from photopeaks falling in the window from the decay of nuclei for which the window was meant to detect; second is a contribution from photopeaks falling partially in the window from the decay of other 
TABLE A-1

Some of the Prominent KUT Photo Peaks Falling at Least Partially in the KUT Windows $(1,2)$

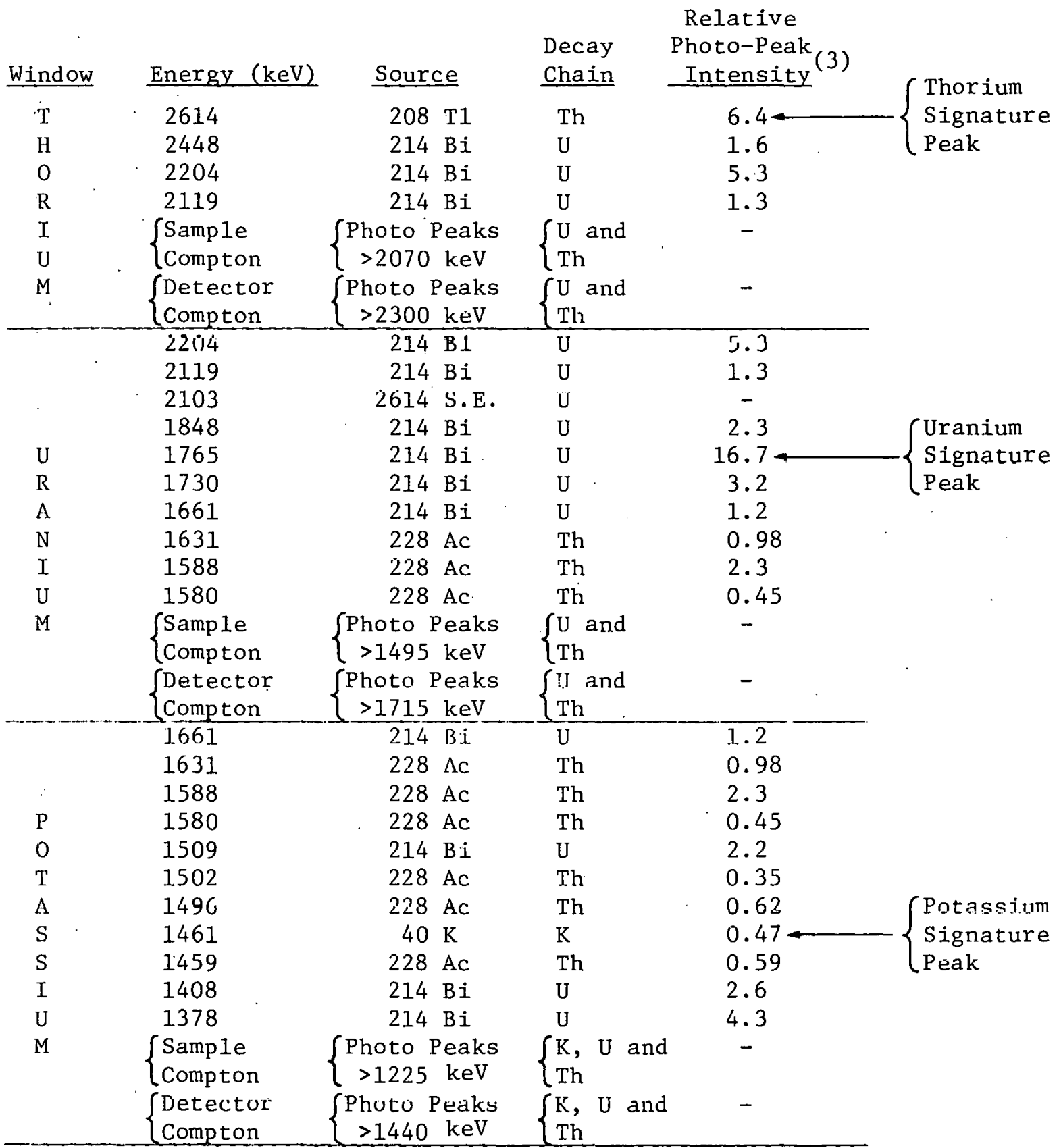

Note: (1) Contributions in windows due to pile-up are neglected.

(2) Because of the inherent.1.y poor resolution ( $\because 9$ percent) of NaI detectors, window contributions will occur from outside the window settings.

$$
\begin{array}{lcc} 
& \text { Window } & \text { Fringe } \\
\text { K } & 1360-1560 & 1.240-1700 \\
\text { U } & 1660-2300 & 1510-2505 \\
\text { T } & 2300-3000 & 2095-3270
\end{array}
$$

(3) Assumes concentrations of 5 percent $\mathrm{K}, 500 \mathrm{ppm} \mathrm{U}$, and $100 \mathrm{ppm} \mathrm{Th}$. 
radionuclides present in the the sample 13; third, and usually largest, is a contribution from Compton scattered photons. In the analysis of the data, it is necessary to subtract out the latter two contributions. The problem with this is not the extra mathematics but the additional uncertainties (errors) that can result.

\section{3) Brief Description of the Ge(Li) Technique}

As a result of the $\mathrm{Ge}(\mathrm{L} i)$ gamma spectrometer developmental project it is possible to use only photopeak data in the determination of KUT concentrations. This is achieved by the use of a high resolution Ge(Li) detection system ( 50 times greater resolution than the present NaI system) in conjunction with a larger multichannel analyzer. See Figure A-3 for a graphic comparison of $\mathrm{NaI}(\mathrm{T} 1)$ and $\mathrm{Ge}(\mathrm{Li})$ spectrometer resolution. Table A-2 identifies the many peaks observed in the $\mathrm{Ge}(\mathrm{Li})$ spectrum. As a result of the higher resolution of the spectrometer, interfering photopeaks are eliminated (the second contribution discussed above for the present KUT system). Similarly, as a result of higher resolution, the Compton continuum (the third contribution above) can be accounted for by the ability to accurately establish the background under the photopeaks. Accordingly, the equations for calculating KUT concentrations are simply:

$$
\begin{aligned}
\mathrm{ThO}_{2}(\mathrm{ppm}) & =\frac{\mathrm{S}_{\mathrm{ThO}_{2}} \mathrm{R}_{2614}}{\mathrm{~W}} \\
\mathrm{gU}_{3} \mathrm{O}_{8}(\mathrm{ppm}) & =\frac{\mathrm{S}_{\mathrm{gU}_{3} \mathrm{O}_{8}} \mathrm{R}_{1765}}{\mathrm{~W}} \\
\mathrm{~K}(\%) & =\frac{\mathrm{S}_{\mathrm{K}} \mathrm{R}_{1461}}{\mathrm{~W}}
\end{aligned}
$$

The symbols were defined previously for equations (1), (2), and (3). Here a distinction has been made in the uranium concentration, with $8_{U_{3}} 0_{8}(\mathrm{ppm})$ taken to mean uranium concentration as determined using the $214 \mathrm{Bi} 1765 \mathrm{keV}$ line. The reason for this is that this technique can be used to determine $235 \mathrm{U}$ and/or $238_{\mathrm{U}}$ direct1y 14 , requiring no assumption of secular equilibrium. Equation (3) assumes there is no interference from the $1459 \mathrm{keV}$ intensity of ${ }^{208} \mathrm{~T} 1$.

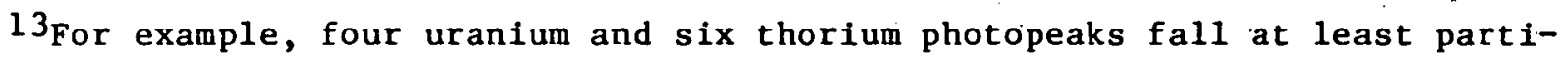
ally in the potassium window.

${ }^{14}$ For a more complete discussion of this technique, see Ken Kosanke, "Sample, Assay Using a Ge(Li) Detector," R\&D Project \#5001, September, 1975. Also, see the main text of this report. 
Comparison of $\mathrm{Nal} \& \mathrm{Ge}(\mathrm{Li})$ Detector Resolution

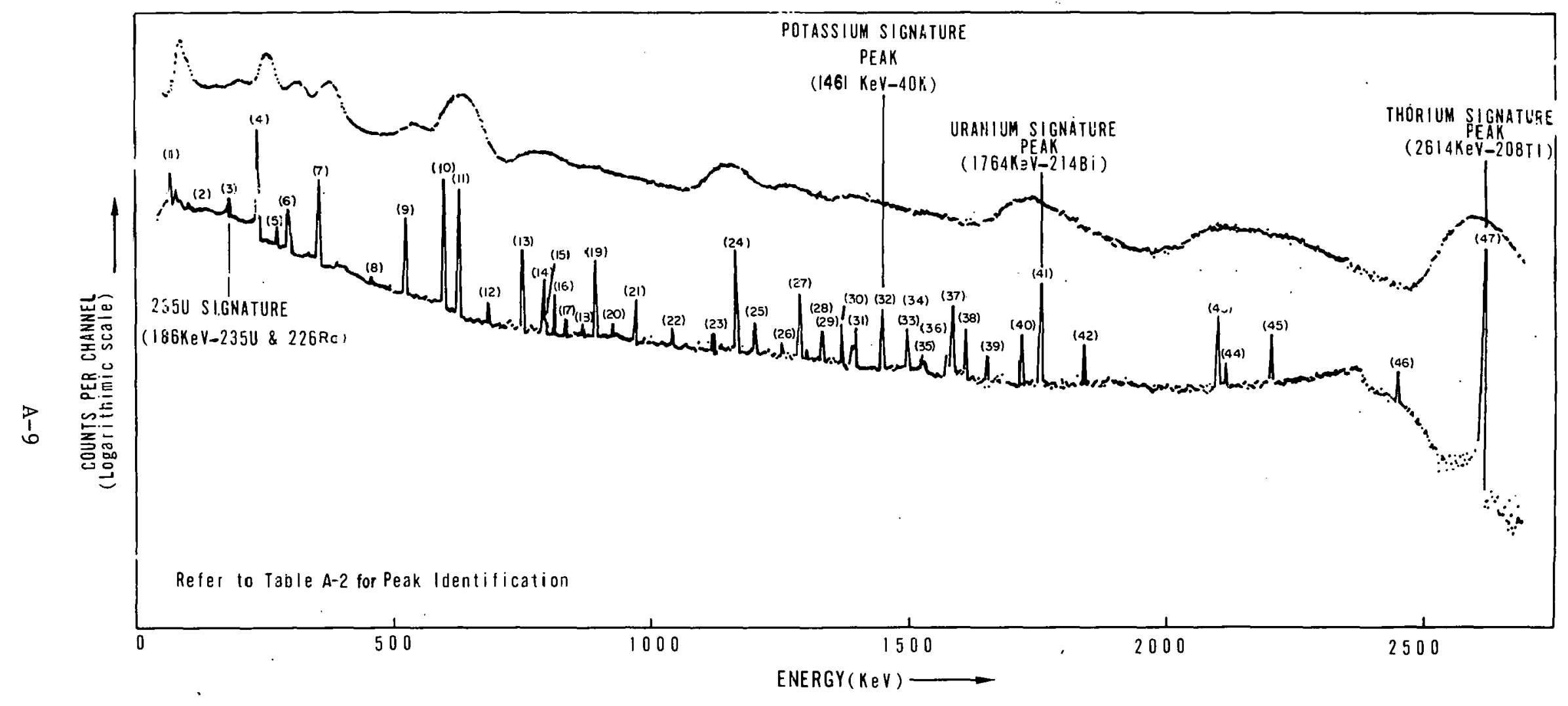

FIGURE A-3. Comparison of $\mathrm{NaI}$ and $\mathrm{Ge}(\mathrm{Li})$ Detector Resolution 
TABLE A-2

Peak Identification for Figure A-3

\begin{tabular}{|c|c|c|c|c|c|c|c|}
\hline $\begin{array}{l}\text { Data } \\
\text { Point }\end{array}$ & $\begin{array}{l}\text { Energy } \\
(\mathrm{keV})\end{array}$ & $\begin{array}{l}\text { Source } \\
\text { Nuclide }\end{array}$ & $\begin{array}{l}\text { Decay } \\
\text { Chain } \\
\end{array}$ & $\begin{array}{l}\text { Data } \\
\text { Point }\end{array}$ & $\begin{array}{l}\text { Energy } \\
(\mathrm{keV})\end{array}$ & $\begin{array}{l}\text { Source } \\
\text { Nuclide }\end{array}$ & $\begin{array}{l}\text { Decay } \\
\text { Chain }\end{array}$ \\
\hline (1) & $<100$ & $\mathrm{X}$-rays & & (23) & 1079 & ${ }^{212} \mathrm{Bi}$ & 232 'I'h \\
\hline (2) & 144 & ${ }^{23} 5_{U}$ & $235_{U}$ & (24) & 1120 & $214 \mathrm{Bi}$ & $238_{\mathrm{U}}$ \\
\hline \multirow[t]{2}{*}{ (3) } & $\{186$ & ${ }^{23} 5_{U}$ & ${ }^{23} 5_{U}$ & (25) & 1156 & ${ }^{214} \mathrm{Bi}$ & ${ }^{23} 8_{\mathrm{U}}$ \\
\hline & $\{186$ & ${ }^{226} \mathrm{Ra}$ & $238_{U}$ & (26) & 1208 & ${ }^{214} \mathrm{Bi}$ & $238_{U}$ \\
\hline \multirow[t]{2}{*}{ (4) } & $\{239$ & ${ }^{212} \mathrm{~Pb}$ & ${ }^{232} \mathrm{Th}$ & (27) & 1238 & ${ }^{214} \mathrm{Bi}$ & $238_{U}^{\circ}$ \\
\hline & 242 & ${ }^{214} \mathrm{Bi}$ & $238_{U}$ & (28) & 1254 & 1765S.E. & $238_{U}$ \\
\hline \multirow{2}{*}{ (5) } & $\{270$ & $228 \mathrm{AC}$ & $232 \mathrm{Th}$ & (29) & 1281 & ${ }^{214} \mathrm{Bi}$ & $.238_{\mathrm{U}}$ \\
\hline & $\{277$ & ${ }^{208} \mathrm{~T} 1$ & ${ }^{232} \mathrm{Th}$ & (30) & 1378 & ${ }^{214} \mathrm{Bi}$ & $238_{U}$ \\
\hline (6) & 295 & $214 \mathrm{~Pb}$ & $238_{U}$ & (31) & 1408 & ${ }^{214} \mathrm{Bi}$ & $238_{U}$ \\
\hline (7) & 352 & $214 \mathrm{~Pb}$ & $238_{U}$ & (32) & 1461 & $40_{K}$ & $40_{K}$ \\
\hline (8) & 463 & $228 \mathrm{AC}$ & ${ }^{232} \mathrm{Th}$ & (33) & 1509 & $214_{\mathrm{Bi}}$ & $238 \mathrm{U}$ \\
\hline (9) & 511 & $208 \mathrm{~T} 1$ & $232 \mathrm{Th}$ & (34) & 1539 & $214 \mathrm{Bi}$ & $238_{\mathrm{U}}$ \\
\hline (10) & .583 & ${ }^{208} \mathrm{~T} 1$ & ${ }^{232} \mathrm{Th}$ & (35) & 1543 & ${ }^{214} \mathrm{Bi}$ & $238 \mathrm{U}$ \\
\hline (11) & 609 & $214_{\mathrm{Bi}}$ & $238_{U}$ & (36) & 1588 & ${ }^{228} \mathrm{AC}$ & ${ }^{232} \mathrm{Th}$ \\
\hline (12) & 665 & $214 \mathrm{Bi}$ & $238_{U}$ & (37) & 1592 & 2614D.E. & $232 \mathrm{Th}$ \\
\hline (13) & 727 & ${ }^{212} \mathrm{Bi}$ & $232 \mathrm{Th}$ & (38) & 1631 & ${ }^{228} \mathrm{AC}$ & $238_{U}$ \\
\hline (14) & .769 & $214 \mathrm{Bi}$ & $238_{U}$ & (39) & 1661 & $214 \mathrm{Bi}$ & $238_{U}$ \\
\hline (15) & 772 & $228 \mathrm{AC}$ & ${ }^{232} \mathrm{Th}$ & $(40)$ & 1730 & ${ }^{214} \mathrm{Bi}$ & 238 \\
\hline$(16)$ & 795 & ${ }^{228} \mathrm{AC}$ & ${ }^{238}{ }_{\mathrm{U}}$ & (41) & 1765 & ${ }^{21.4} \mathrm{Bi}$ & ${ }^{238} \mathrm{U}$ \\
\hline (17) & 806 & ${ }^{214} \mathrm{Bi}$ & ${ }^{238}{ }_{\mathrm{U}}$ & (42) & 1848 & ${ }^{214} \mathrm{Bi}$ & $238 \mathrm{U}$ \\
\hline (18) & 836 & ${ }^{228} \mathrm{AC}$ & ${ }^{232} \mathrm{Th}$ & (43) & 2103 & 2614S.E. & ${ }^{232} \mathrm{Th}$ \\
\hline (19) & 860 & ${ }^{208} \mathrm{~T} 1$ & $232 \mathrm{Th}$ & (44) & 2119 & ${ }^{214} \mathrm{Bi}$ & $238_{U}$ \\
\hline$(20)$ & 911 & ${ }^{228} \mathrm{AC}$ & ${ }^{232} \mathrm{Th}$ & (45) & 2204 & ${ }^{214} \mathrm{Bi}$ & $238_{U}$ \\
\hline (21) & 935 & $214 \mathrm{Bi}$ & ${ }^{238} \mathrm{U}$ & $(46)$ & 2448 & ${ }^{214} \mathrm{Bi}$ & $238_{U}$ \\
\hline (22) & 1001 & $234 \mathrm{~m}_{\mathrm{Pa}}$ & 238 & $(47)$ & 2614 & $208_{\mathrm{T} 1}$ & $232 \mathrm{Th}$ \\
\hline
\end{tabular}




\begin{abstract}
APPENDIX B
LISTING OF GAMMA TRANSITIONS IN THE $238 \mathrm{U},{ }^{235} \mathrm{U}$, and $232 \mathrm{Th}$ DE'CAY LHALNS

From "High-Resolution Gamma Ray Spectrometry for Laboratory Analysis of the Jranium and Thorium Decay Series" by A. R. Smith and H. A. Wollenberg, contained in The Natural Radiation Environment II. NTIS conf-720805-P-1.

Reproduced with the permission of A. R. Smith, LBL.
\end{abstract}




\section{THIS PAGE}

\section{WAS INTENTIONALLY LEFT BLANK}




\section{APPIENDIX I: GENERAL COMMENTS}

The Ge( $\mathrm{Li}) \boldsymbol{\gamma}$-ray spectrometer can now resolve many of the closely spaced $\gamma$-lines from the natural radioactive heavy-element series (U-238, U-235, Th-232), providing inlormation useful for disequilibrium determinations as well as for the usual "total" $U$ and $T h$ assays. Thus a detailed listing of $\gamma$-ray energies and intensities from these families is of increased practical significance. The compilations given here include experimental data available up to the date of this symposium. General references consulted include Lederer et al. (1967), Way (1965-68; 1966-68; 1968-72), and Nuclear Data Group (1969-72). Specific references have been consulted in cases where new data had been reported since 1966. Such references are included in each section of this appendix, keyed to the isotopes studied.

The $\gamma$-rays within each family are ordered by energy; energies are given in $\mathrm{keV}$; absolute intensities are given in numbers of photons emitted per 100 decays of the longest-lived parent; and identification, as belonging to the decaying nuclide:

Energy values assigned by different experimenters are frequently in agreement to within $0.1 \mathrm{keV}$, except for some of the weaker $\gamma$-lines. On the other hand, intensity values reported by different experimenters often disagree by $5-10 \%$, even for the most intense $\gamma$-lines, with corrrespondingly greater disagreements for the weaker lines. Although energy calibration of $\mathrm{Ge}(\mathrm{Li})$ spectrometers can be reliably accomplished with these sources, it is questionable whether absolute efficiency calibrations can be similarly established until the discrepancies are resolved.

The detailed lists given here call attention to the problem of observing weak $\boldsymbol{\gamma}$-lines that have energies lower than strong $\gamma$-lines. The $\mathrm{Ge}(\mathrm{Li})$ detector response gives a spectral shape in which the total absorption peak stands above the level of its lower-energy continuum by a factor varying between 10 - and 100-fold, depending on $\gamma$-ray energy and region of interest in the continuum. Weak $\gamma$-lines 100 times less intense than a strong higher-energy $\gamma$-line should be easily measurable; $\gamma$-lines as much as 1000-10000 times weaker than the strong line can be observed in favorable cases.

\section{APPENDIX Ia: U-238 DECAY SERIES}

The ratio U-235/U-238 is (nearly) constant in nature; it follows that both decay series will always appear in the same proportions under equilibrium conditions. We include $\mathrm{U}-235$ series $\gamma$-rays along with U-238 $\gamma$-rays for this reason, in proportion calculated from: U-235/U-238 ratio of 0.00711 on a weight basis; U-238 half life of $4.51 \times 10^{9}$ years; and, U-235 half life of $7.13 \times 10^{8}$ years (Hyde et al., 1964). Intensities of U-235 series $\gamma$-rays in this list are 0.0450 times the intensities listed for this series in Appendix Ib. Note that U-235 series members are all odd-mass isotopes, while U-238 series members are all even-mass isotopes; this is a simple way to distinguish between the two families.

In the U-238 series, $\gamma$-rays listed for Ra-226 are derived primarily from the detailed list of Ra-226 in equilibrium with its daughters (Lingeman et al., 1969). We have assigned the $\gamma$-rays from this list to specific daughter nuclides, but all $\gamma$-rays not known to belong to particular nuclides have been assigned to $\mathrm{Bi}-214$. All strong $\gamma$-lines are correctly assigned; it is only some of the weak ones which are inferentially assigned.

\section{ISOTOPE REFERENCES}

U.238 Lederer 1967 
$\mathrm{U}-234$

$\mathrm{Pa}-234$

$\mathrm{Pa}-234 \mathrm{M}$.

Th-234

Th-230

$\mathrm{Ra}-226$

$\mathrm{Rn}-222$

At-218

Po-218

Po-214

Po-210

Bi-2 14

Bi-2 10

$\mathrm{Pb}-214$

$\mathrm{Pb}-210$

TI-210

Tl-206

Hg-206
Lederer 1967

Borggreen 1968, Gunnink 1971, Wapstra 1967

Gunnink 1971, Wapstra 1967

Foucher 1962, Foucher 1965

Lederer 1967

Gunnink 1969, Lederer 1967, Lingeman 1969

Lingeman 1969

Lederer 1967

Lederer 1967

Lederer 1967

Lederer 1967

Gunnink 1969, Lingeman 1969

Lederer 1967

Gunnink 1969, Lingeman 1969

Lederer 1967, Lingeman 1969

Lederer 1967, Lingeman 1969

Lederer 1967

Wolf 1968

\begin{tabular}{|c|c|c|c|c|c|}
\hline ISOTOPE* & $\begin{array}{c}\gamma \text {-ENERGY } \\
(\mathrm{keV})\end{array}$ & $\begin{array}{l}\text { INTENSITY } \\
(\%) \dagger\end{array}$ & ISOTOPE* & $\begin{array}{c}\gamma \text {-ENERGY } \\
(\mathrm{keV})\end{array}$ & $\begin{array}{c}\text { INTENSITY } \\
((\%))^{\dagger}\end{array}$ \\
\hline $\mathrm{Pa}-231$ & 25.54 & $.1 .21 \mathrm{E}-04$ & $\mathrm{Fr}-223$ & 49.80 & $2.34 \mathrm{E}-02$ \\
\hline $\mathrm{Pa}-231$ & 27.35 & $1.26 \mathrm{E}-02$ & Th-227 & 50.20 & $3.86 \mathrm{E}-01$ \\
\hline $\mathrm{Pa}-231$ & 29.95 & $1.24 \mathrm{E}-04$ & Th-227 & 50.70 & 7.111-04 \\
\hline $\mathrm{Pa}-231$ & 31.00 & $1.21 \mathrm{E}-05$ & & & \\
\hline$P: 1-231$ & 31.54 & $9.45 \mathrm{E}-06$ & $P: 1-231$ & 50.98 & $1.891 \div-06$ \\
\hline $\mathrm{Pa}-234$ & 34.30 & $4.74 \mathrm{E}-06$ & Th-227 & 51.20 & unknown \\
\hline $\mathrm{Pa}-231$ & 35.82 & $2.16 \mathrm{E}-05$ & $\mathrm{~Pa}-231$ & 52.74 & $1.15 \mathrm{E}-04$ \\
\hline $\mathrm{Pa}-231$ & 38.20 & $2.01 \mathrm{E}-04$ & $\mathrm{~Pb}-214$ & 53.23 & $2.20 \mathrm{E}+00$ \\
\hline $\mathrm{Pa}-231$ & 39.57 & $1.89 \mathrm{E}-06$ & U-234 & 53.30 & $1.18 \mathrm{E}-01$ \\
\hline $\mathrm{Pa}-231$ & 39.97 & $1.62 \mathrm{E}-05$ & Th-227 & 54.20 & unknown \\
\hline Th-227 & 40.1 .0 & unknown & $\mathrm{Pa}-231$ & 54.61 & $1.09 \mathrm{E}-04$ \\
\hline Th-227 & 42.20 & $3.55 \mathrm{E}-03$ & Th-227 & 56.10 & $8.88 \mathrm{E}-05$ \\
\hline $\mathrm{Pa}-231$ & 42.48 & $8.10 \mathrm{E}-06$ & Pa-231 & 56.76 & $8.10 \mathrm{E}-06$ \\
\hline Th-231 & 42.81 & $2.43 \mathrm{E}-03$ & $\mathrm{~Pa}-231$ & 57.19 & $5.26 \mathrm{E}-05$ \\
\hline $\mathrm{Pa}-231$ & 43.05 & $9.45 \mathrm{E}-06$ & $\mathrm{~Pa}-234$ & 58.20 & $7.11 E-06$ \\
\hline $\mathrm{Pa}-234$ & 43.40 & $3.32 \mathrm{E}-04$ & Th-23 I & 58.55 & $1.89 \mathrm{E}-02$ \\
\hline Th-227 & 43.50 & $1.07 \mathrm{E}-02$ & Th-227 & 59.60 & $4.00 \mathrm{E}-04$ \\
\hline Th-227 & 43.80 & 2.22E-03 & Pa-231 & 60.50 & $9.45 \mathrm{E}-06$ \\
\hline Th- 227 & 44.10 & $3.11 \mathrm{E}-04$ & Th-2 27 & 61.50 & unknown \\
\hline Pal-231 & 44.16 & $8.10 \mathrm{E}-05$ & Th-227 & 62.00 & unknown \\
\hline Th-227 & 44.30 & $5.77 \mathrm{E}-04$ & Th-227 & 62.50 & $1.111-02$ \\
\hline $\mathrm{Pa}-234$ & 45.19 & $2.37 \mathrm{E}-05$ & Th-227 & 62.70 & $4.00 \mathrm{E}-04$ \\
\hline $\mathrm{Pa}-231$ & 46.37 & $2.81 \mathrm{E}-04$ & Th-234 & 62.80 & $6.70 \mathrm{E}-03$ \\
\hline$P b-210$ & 46.52 & 4. $10 \mathrm{E}+00$ & Th-234 & 63.30 & $5.69 \mathrm{E}+00$ \\
\hline Th- 227 & 48.30 & unknown & $\mathrm{Pa}-234$ & 63.40 & $6.64 \mathrm{E} 03$ \\
\hline Th-227 & 48.50 & $2.00 \mathrm{E}-03$ & $\mathrm{~Pa}-231$ & 63.67 & $6.75 \mathrm{E}-05$ \\
\hline Th-227 & 49.80 & 8.88E-03 & Th-227 & 64.50 & $1.24 \mathrm{E}-03$ \\
\hline
\end{tabular}

*Decaying isotope

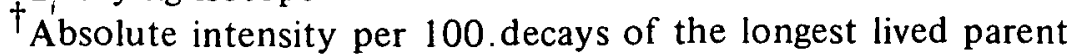




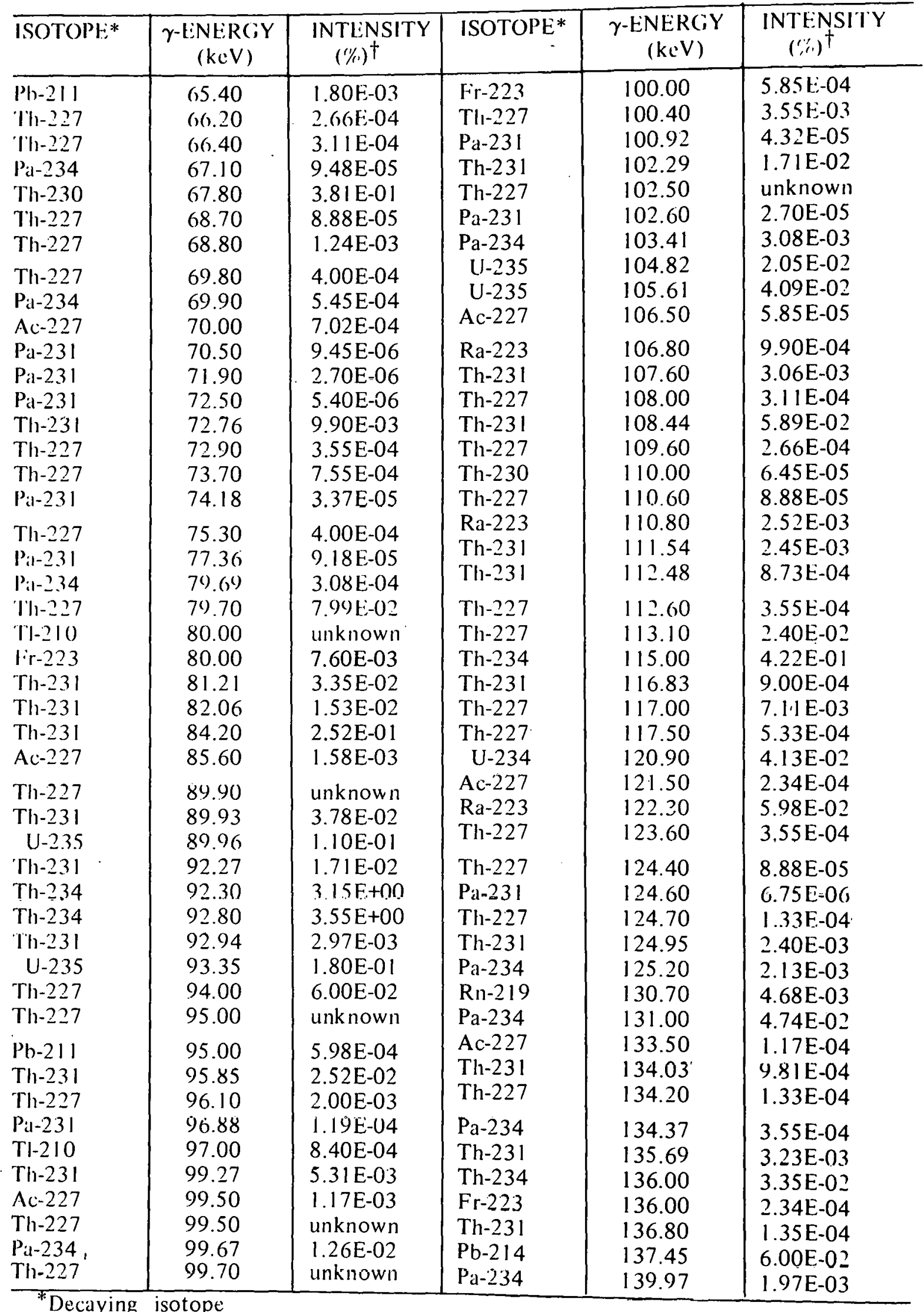

Decaying isotope

$\dagger$ Absolute intensity per 100 decays of the longest lived parent 


\begin{tabular}{|c|c|c|c|c|c|}
\hline ISOTOPE* & $\begin{array}{c}\gamma \text {-ENERGY } \\
(\mathrm{keV})\end{array}$ & $\begin{array}{l}\text { INTENSITY } \\
(\%)^{\dagger}\end{array}$ & ISOTOPE* & $\begin{array}{c}\gamma \text {-ENERGY } \\
(\mathrm{keV})\end{array}$ & $\begin{array}{l}\text { INTENSITY } \\
(\%,)^{\dagger}\end{array}$ \\
\hline $\begin{array}{r}\text { Th-227 } \\
\text { U-235 } \\
\text { Th-2277 }\end{array}$ & $\begin{array}{l}140.50 \\
140.75 \\
141.20\end{array}$ & $\begin{array}{l}1.42 \mathrm{E}-03 \\
9.36 \mathrm{E}-03 \\
2.89 \mathrm{E}-03\end{array}$ & $\begin{array}{r}P a-234 \\
U-235 \\
P b-214\end{array}$ & $\begin{array}{l}193.40 \\
194.94 \\
196.30\end{array}$ & $\begin{array}{l}1.90 \mathrm{E}-0.3 \\
2.77 \mathrm{E}-02 \\
5.00 \mathrm{E}-02\end{array}$ \\
\hline $\begin{array}{r}\mathrm{Pb}-214 \\
\mathrm{Th}-230 \\
\mathrm{U}-235 \\
\mathrm{Ra}-223\end{array}$ & $\begin{array}{l}141.30 \\
142.00 \\
143.77 \\
144.19\end{array}$ & $\begin{array}{l}4.00 \mathrm{E}-0 ? \\
4.51 \mathrm{E}-02 \\
4.81 \mathrm{E}-01 \\
1.41 \mathrm{E}-01\end{array}$ & $\begin{array}{l}\mathrm{Pa}-234 \\
\mathrm{Th}-227 \\
\mathrm{~Pa}-231 \\
\mathrm{~Pa}-234\end{array}$ & $\begin{array}{l}196.40 \\
197.60 \\
199.00 \\
199.70\end{array}$ & $\begin{array}{l}1.18 \mathrm{E}-0.3 \\
4.44 \mathrm{E}-04 \\
8.10 \mathrm{E}-06 \\
2.37 \mathrm{E}-0.3\end{array}$ \\
\hline Pa-234 & 144.35 & $7.11 \mathrm{E}-04$ & Th-2227 & 200.50 & 2.2ㄹ-(04 \\
\hline Pa-231 & 144.50 & 1.62E-05 & $P a-234$ & 200.60 & $2.37 \mathrm{E}-0.3$ \\
\hline Thl-231 & 145.13 & $2.52 \mathrm{E}-04$ & Th-227 & 201.80 & $9.77 \mathrm{E}-04$ \\
\hline Th-231 & 145.96 & $1.26 \mathrm{E}-03$ & U-235 & 202.10 & $4.81 \mathrm{E}-02$ \\
\hline$A c-227$ & 147.00 & $3.51 \mathrm{E}-04$ & Thi-227 & 202.50 & $2.66 \mathrm{~F}-04$ \\
\hline Th1-22.7 & 149.80 & 7.99E-04 & $P a-2.34$ & 202.90 & $2.841:-0.3$ \\
\hline$P a 1-2.34$ & 150.20 & $4.741:-(04$ & Th-227 & 204.20 & $1.021:-02$ \\
\hline Pal-234 & 152.46 & $1.42 \mathrm{E}-02$ & $\mathrm{Fr}-223$ & 205.00 & $4.681-04$ \\
\hline $\mathrm{Ra}-223$ & 154.18 & $2.35 \mathrm{E}-01$ & Th- 227 & 205.20 & $7.55 \mathrm{E}-0.3$ \\
\hline Th-234 & 155.00 & 2. $68 \mathrm{E}-02$ & U-235 & 205.33 & $2.19 \mathrm{E}-01$ \\
\hline $\mathrm{Ra}-223$ & 158.62 & $3.42 \mathrm{E}-02$ & $\mathrm{~Pb}-214$ & 205.59 & $1.50 E-02$ \\
\hline$P a-234$ & 159.10 & 1.18E-03 & Th-230 & 206.00 & 3.22E-06 \\
\hline Ac- 227 & 160.00 & 8.19E-04 & Th-227 & 206.10 & $1.15 \mathrm{E}-02$ \\
\hline Th-227 & 162.20 & $2.66 \mathrm{E}-04$ & Th-227 & 206.40 & $1.78 \mathrm{E}-04$ \\
\hline Th-231 & 163.16 & $6.25 \mathrm{E}-03$ & Th-227 & 210.60 & $5.60 \mathrm{E}-02$ \\
\hline U-235 & 163.37 & 2.18E-01 & Th-227 & 212.60 & $3.78 \mathrm{E}-(0) 3$ \\
\hline Th-234 & 167.00 & $2.68 \mathrm{E}-02$ & Th-227 & 212.70 & $7.55 \mathrm{~F}-04$ \\
\hline$T h-227$ & 168.20 & $6.22 \mathrm{E}-04$ & U-235 & 215.35 & $1.241:-0.3$ \\
\hline $\mathrm{Fr}-223$ & 170.00 & $1.40 \mathrm{E}-04$ & Th-227 & 218.80 & $2.44 \mathrm{E}-0.3$ \\
\hline Th- 227 & 170.10 & 1.33E-04 & Th-2227 & 219.00 & 2.00t:-03 \\
\hline $\bar{P}_{\mathrm{a}-1}-234$ & 170.77 & $1.18 \mathrm{E}-0.3$ & Pat-2.34 & 219.60 & $4.741:-(1) 4$ \\
\hline Th-227 & 171.40 & unknown & $R_{n 1}-219$ & 222.00 & 1.2(01:-(0.3 \\
\hline Ac- -227 & 172.00 & 2.34E-04 & Th-2227 & 224.70 & $6.66 \mathrm{E}-04$ \\
\hline Th-227 & 173.40 & 4.89E-04 & $\mathrm{Pa}-234$ & 226.15 & 1.52E-0? \\
\hline Th-227 & 175.80 & 7.99E-04 & $\mathrm{Pa}-234$ & 227.00 & $1.42 \mathrm{E}-02$ \\
\hline $\mathrm{Ra}-223$ & 176.00 & $9.45 \mathrm{E}-04$ & Th-227 & 230.40 & unknown \\
\hline $\mathrm{Ra}-223$ & 177.30 & $9.45 \mathrm{E}-04$ & U-235 & 233.54 & 1. $24 \mathrm{E}-03$ \\
\hline $\mathrm{Ra}-223$ & 179.60 & $6.75 \mathrm{E}-03$ & Fr-223 & 234.00 & $2.11 \mathrm{E}-03$ \\
\hline $\mathrm{Pa}-234 \mathrm{M}$ & 182.50 & $1.66 \mathrm{E}-03$ & Th-227 & 234.90 & 2.58E-02 \\
\hline $\mathrm{U}-235$ & 182.57 & $1.62 \mathrm{E}-02$ & Th-230 & 235.00 & 3.22E-06 \\
\hline Th-234 & 184.00 & $1.34 \mathrm{E}-02$ & Th-227 & 236.00 & $5.11 \mathrm{E}-01$ \\
\hline Th-230 & 184.00 & $9.03 E-03$ & Pb-214 & 238.40 & $1.50 \mathrm{E}-02$ \\
\hline Th-227 & 184.70 & 1.20E-03 & U-235 & 240.93 & $2.88 \mathrm{E}-03$ \\
\hline U-235 & 185.72 & $2.52 \mathrm{E}+00$ & $\mathrm{~Pb}-214$ & 241.92 & $7.60 E+00$ \\
\hline Рa-234 & 185.95 & $4.03 E-03$ & $\mathrm{~Pa}-231$ & 242.20 & $1.08 E-05$ \\
\hline$R_{i 1}-226$ & 186.00 & $3.90 \mathrm{E}+00$ & Pa-231 & 243.00 & 4.591:-05 \\
\hline$A c-227$ & 190.00 & 2.9 2E-05 & P:il-2.34 & 245.00 & $2.371:-0.3$ \\
\hline $\mathrm{Fr}-223$ & 190.00 & unknown & Pal-231 & 245.40 & $9.45 \mathrm{E}-00$ \\
\hline \multirow{2}{*}{$R_{i 1}-223$} & 193.00 & $4.50 \mathrm{r}-04$ & Pai-231 & 246.00 & $1.351 \%-(06$ \\
\hline & & & Th-227 & 246.40 & $5.3 .31:-(1) 4$ \\
\hline
\end{tabular}

*Decaying isotope

${ }^{\dagger}$ Absolute intensity per 100 decays of the longest lived parent 
Migh-Resolution Spectrometry Of Natural Seriess

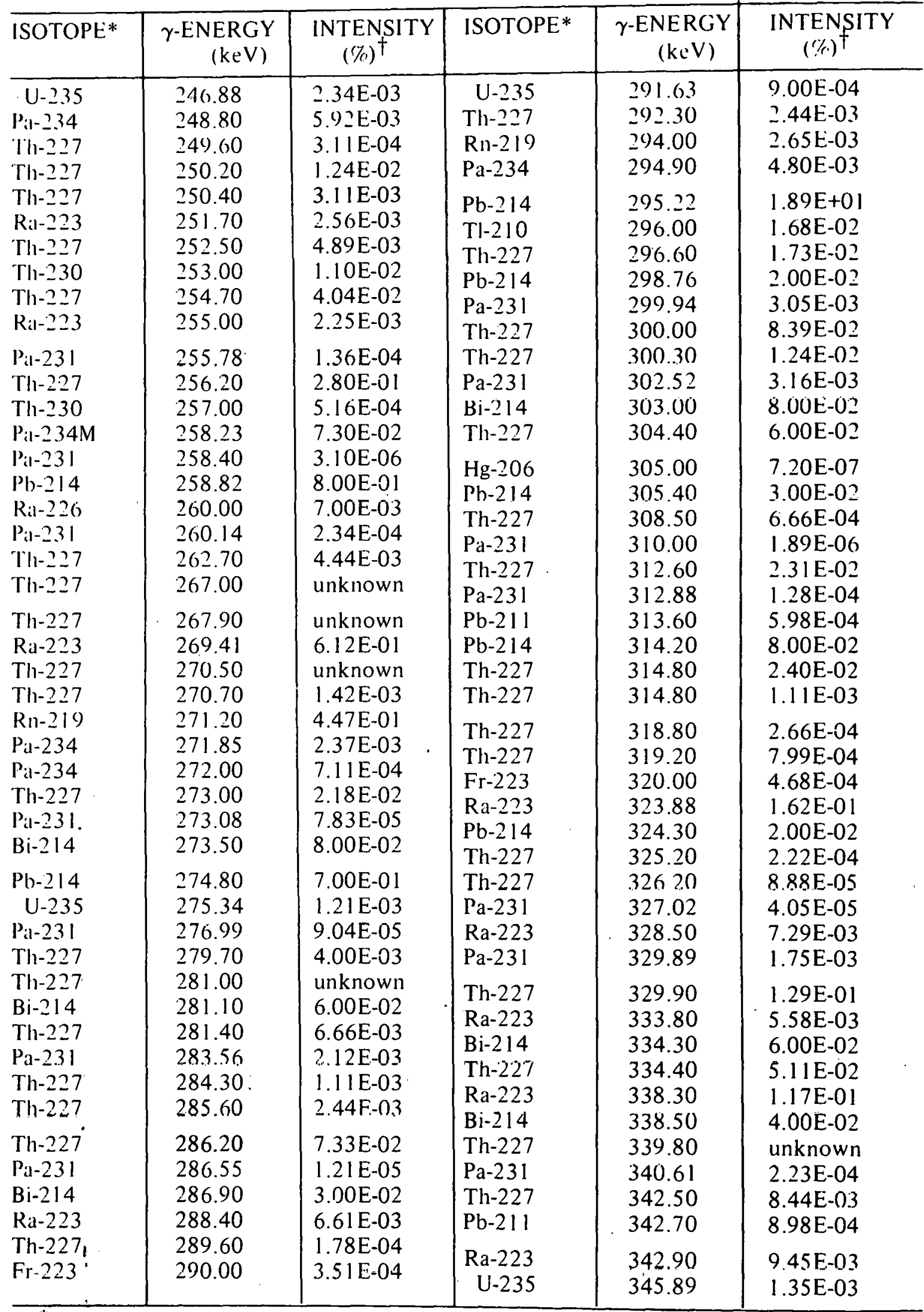

${ }^{*}$ Decaying isotope

${ }^{\dagger}$ Absolute intensity per 100 decays of the longest lived parent 


\begin{tabular}{|c|c|c|c|c|c|}
\hline ISOTOPE* & $\begin{array}{c}\gamma \text {-ENERGY } \\
(\mathrm{keV})\end{array}$ & $\begin{array}{l}\text { INTENSITY } \\
(\%)^{\dagger}\end{array}$ & ISOTOPE* & $\begin{array}{c}\gamma \text {-ENERGY } \\
(\mathrm{keV})\end{array}$ & $\begin{array}{l}\text { INTENSITY } \\
(\%)^{\dagger}\end{array}$ \\
\hline Th-227 & 346.30 & $3.55 \mathrm{E}-04$ & $\mathrm{Bi}-214$ & 426.50 & $1.00 \mathrm{E}-01$ \\
\hline $\mathrm{Ra}-223$ & 346.80 & $7.65 \mathrm{E}-03$ & $\mathrm{~Pb}-211$ & 426.90 & 8.20E-02 \\
\hline Th-227 & 348.50 & $2.66 \mathrm{E}-04$ & $\mathrm{~Pb}-211$ & 429.10 & $3.89 \mathrm{E}-04$ \\
\hline $\mathrm{Fr}-223$ & 350.00 & 5.85E-05 & $\mathrm{Ra}-223$ & 432.00 & $1.35 \mathrm{E}-03$ \\
\hline Th-227 & 350.50 & $3.55 \mathrm{E}-04$ & Th-227 & 432.50 & $1.78 \mathrm{E}-04$ \\
\hline $\mathrm{Bi}-211$ & 351.10 & $5.98 \mathrm{E}-01$ & $\mathrm{~Pa}-231$ & 435.10 & $4.45 \mathrm{E}-06$ \\
\hline $\mathrm{Pb}-214$ & 351.99 & $3.63 \mathrm{E}+01$ & $\mathrm{~Pa}-231$ & 437.90 & $5.53 \mathrm{E}-06$ \\
\hline Th-227 & 352.60 & $4.00 \mathrm{E}-04$ & $\mathrm{~Pa}-231$ & 438.70 & $2.02 \mathrm{E}-06$ \\
\hline $\mathrm{Pa}-231$ & 354.38 & $1.28 \mathrm{E}-04$ & $\mathrm{Bi}-214$ & 440.40 & $3.00 \mathrm{E}-02$ \\
\hline $\mathrm{Pa}-231$ & 356.96 & $2.34 \mathrm{E}-04$ & $\mathrm{Ra}-223$ & 444.92 & $5.71 \mathrm{E}-02$ \\
\hline Pa-231 & 359.25 & $1.21 \mathrm{E}-05$ & $\mathrm{~Pa}-234 \mathrm{M}$ & 451.00 & $3.50 \mathrm{E}-03$ \\
\hline $\mathrm{Tl}-210$ & 360.00 & 8.40E-04 & $\mathrm{Pa}-234$ & 453.90 & $2.10 \mathrm{E}-03$ \\
\hline $\mathrm{Ra}-223$ & 361.50 & $2.25 \mathrm{E}-03$ & $\mathrm{Bi}-214$ & 455.00 & $2.80 \mathrm{E}-01$ \\
\hline Th-227 & 362.50 & $1.78 \mathrm{E}-04$ & $\begin{array}{l}\mathrm{P}-214 \\
\mathrm{~Pa}-234\end{array}$ & 458.20 & $2.20 \mathrm{E}-03$ \\
\hline $\mathrm{Pa}-231$ & 363.74 & $9.99 \mathrm{E}-06$ & $\begin{array}{r}\mathrm{Pa}-234 \\
\mathrm{U}-234\end{array}$ & $\begin{array}{l}450.20 \\
460.00\end{array}$ & $1.18 \mathrm{E}-05$ \\
\hline Th-227 & 369.40 & $1.78 \mathrm{E}-04$ & $\mathrm{~Pb}-214$ & $\begin{array}{l}400.00 \\
462.10\end{array}$ & $1.70 \mathrm{E}-01$ \\
\hline $\mathrm{Pa}-234$ & 369.50 & 4.80E-03 & $\mathrm{Pa}-234$ & $\begin{array}{l}402.10 \\
468.30\end{array}$ & $1.96 \mathrm{E}-03$ \\
\hline Th-227 & 370.90 & 8.88E-05 & $\mathrm{Pb}-214$ & 470.60 & $1.00 \mathrm{E}-02$ \\
\hline Ra-223 & 371.50 & $2.43 \mathrm{E}-02$ & $\mathrm{Bi}-214$ & 474.60 & $7.00 \mathrm{E}-02$ \\
\hline $\mathrm{Pa}-234$ & 371.90 & $2.30 \mathrm{E}-03$ & $\mathrm{~Pa}-234$ & 475.90 & $1.73 \mathrm{E}-03$ \\
\hline $\mathrm{Pa}-231$ & 374.90 & $6.21 \mathrm{E}-06$ & $\mathrm{Tl}-210$ & 480.00 & $4.20 \mathrm{E}-04$ \\
\hline Th-227 & 375.10 & 4.44E-05 & $\mathrm{Pb}-214$ & 480.50 & $3.40 \mathrm{E}-01$ \\
\hline $\mathrm{Ra}-223$ & 376.00 & $5.40 \mathrm{E}-04$ & Pa-231 & $\begin{array}{l}400.50 \\
48670\end{array}$ & $\begin{array}{l}3.4 U \mathrm{E}-\mathrm{U} \\
243 \mathrm{E}-06\end{array}$ \\
\hline$P a-231$ & 379.09 & $6.61 \mathrm{E}-05$ & $\mathrm{Ph}-214$ & $\begin{array}{l}400.10 \\
48725\end{array}$ & $\begin{array}{l}2.43 \mathrm{E}-00 \\
330 \mathrm{E}-01\end{array}$ \\
\hline TI-210 & 380.00 & $6.30 \mathrm{E}-04$ & Ra-223 & 48800 & $\begin{array}{l}3.30 \mathrm{E}-\mathrm{U} \\
675 \mathrm{~F}_{-} \mathrm{C}\end{array}$ \\
\hline Th-227 & 382.40 & $2.66 \mathrm{E}-04$ & $\begin{array}{l}\mathrm{Ka}-223 \\
\mathrm{P}_{\mathrm{a}-231}\end{array}$ & $\begin{array}{l}400.00 \\
49100\end{array}$ & $675 \mathrm{~F}_{-}-07$ \\
\hline $\mathrm{Ra}-223$ & 382.50 & $6.75 \mathrm{E}-04$ & $\mathrm{~Pa}-231$ & 501.60 & $8.10 \mathrm{E}-07$ \\
\hline Th-227 & 383.60 & $8.88 \mathrm{E} .05$ & $\mathrm{~Pb}-211$ & 503.60 & $3.59 \mathrm{E}-05$ \\
\hline$P a-231$ & 384.70 & $5.53 \mathrm{E}-06$ & $\mathrm{~Pa}-231$ & 509.00 & $4.05 \mathrm{E}-07$ \\
\hline $\mathrm{Bi}-214$ & 386.80 & $3.10 \mathrm{E}-01$ & U-234 & 510.00 & $1.18 \mathrm{E}-05$ \\
\hline $\mathrm{Pa}-231$ & 387.00 & $6.75 \mathrm{E}-07$ & $R n-222$ & 511.00 & 1.00E-0I \\
\hline U-235 & 387.81 & $5.40 \mathrm{E}-04$ & $\mathrm{~Pb}-214$ & 511.00 & $3.00 \mathrm{E}-02$ \\
\hline $\mathrm{Bi}-214$ & 388.80 & $3.70 \mathrm{E}-01$ & Pa-231 & 51620 & $175 \mathrm{~F}_{-} 06$ \\
\hline Pa-231 & 391.50 & $9.18 \mathrm{E}-06$ & $R n-219$ & 516.20 & 9 9OE-04 \\
\hline Th1-227 & 392.40 & 4.00E-04 & $\mathrm{Ra}-223$ & 52700 & $315 \mathrm{E}-\mathrm{-O}$ \\
\hline $\mathrm{Ra}-223$ & 393.50 & $4.95 \mathrm{E}-04$ & $\mathrm{~Pb}-214$ & 53380 & $\begin{array}{l}3.13 E-U S \\
170 E_{-}\end{array}$ \\
\hline$P a-231$ & 395.50 & $3.51 \mathrm{E}-06$ & Pa-231 & $\begin{array}{l}535.00 \\
53520\end{array}$ & $675 E-07$ \\
\hline$B i-214$ & 396.30 & $3.00 \mathrm{E}-02$ & $\mathrm{Bi}-214$ & 536.60 & $4.00 \mathrm{E}-02$ \\
\hline$P_{a 1-231}$ & 398.10 & $1.26 \mathrm{E}-05$ & Pb-214 & 538.70 & $5.00 \mathrm{E}-03$ \\
\hline Rn-219 & 401.80 & $2.92 \mathrm{E}-01$ & $\mathrm{Bi}-214$ & 543.50 & $1.00 \mathrm{E}-01$ \\
\hline Th-227 & 402.50 & $1.78 \mathrm{E}-04$ & $\mathrm{~Pa}-234$ & 544.00 & $3.50 \mathrm{E}-03$ \\
\hline $\mathrm{Pb}-211$ & 404.80 & $1.77 \mathrm{E}-01$ & $\mathrm{~Pb}-214$ & 544.00 & $6.00 \mathrm{E}-02$ \\
\hline $\mathrm{Bi}-214$ & 405.90 & $1.50 \mathrm{E}-01$ & $\mathrm{~Pa}-231$ & 546.60 & $8.10 \mathrm{E}-07$ \\
\hline Pal-231 & 407.71 & 4.86E-05 & $\mathrm{Bi}-214$ & 546.80 & $3.00 \mathrm{E}-02$ \\
\hline$P \cdot d-231$ & 410.50 & $2.56 \mathrm{E}-06$ & $\mathrm{~Pa}-234$ & 569.29 & $2.02 \mathrm{E}-02$ \\
\hline Th-227 & 415.20 & 4.44E-05 & Po-211 & 569.60 & $7.20 \mathrm{E}-05$ \\
\hline$R a-226$ & 420.00 & $2.00 \mathrm{E}-04$ & Pa-231 & 572.10 & $6.75 \mathrm{E}-07$ \\
\hline
\end{tabular}

*Decaying isotope

tAbsolute intensity per 100 decays of the longest lived parent 


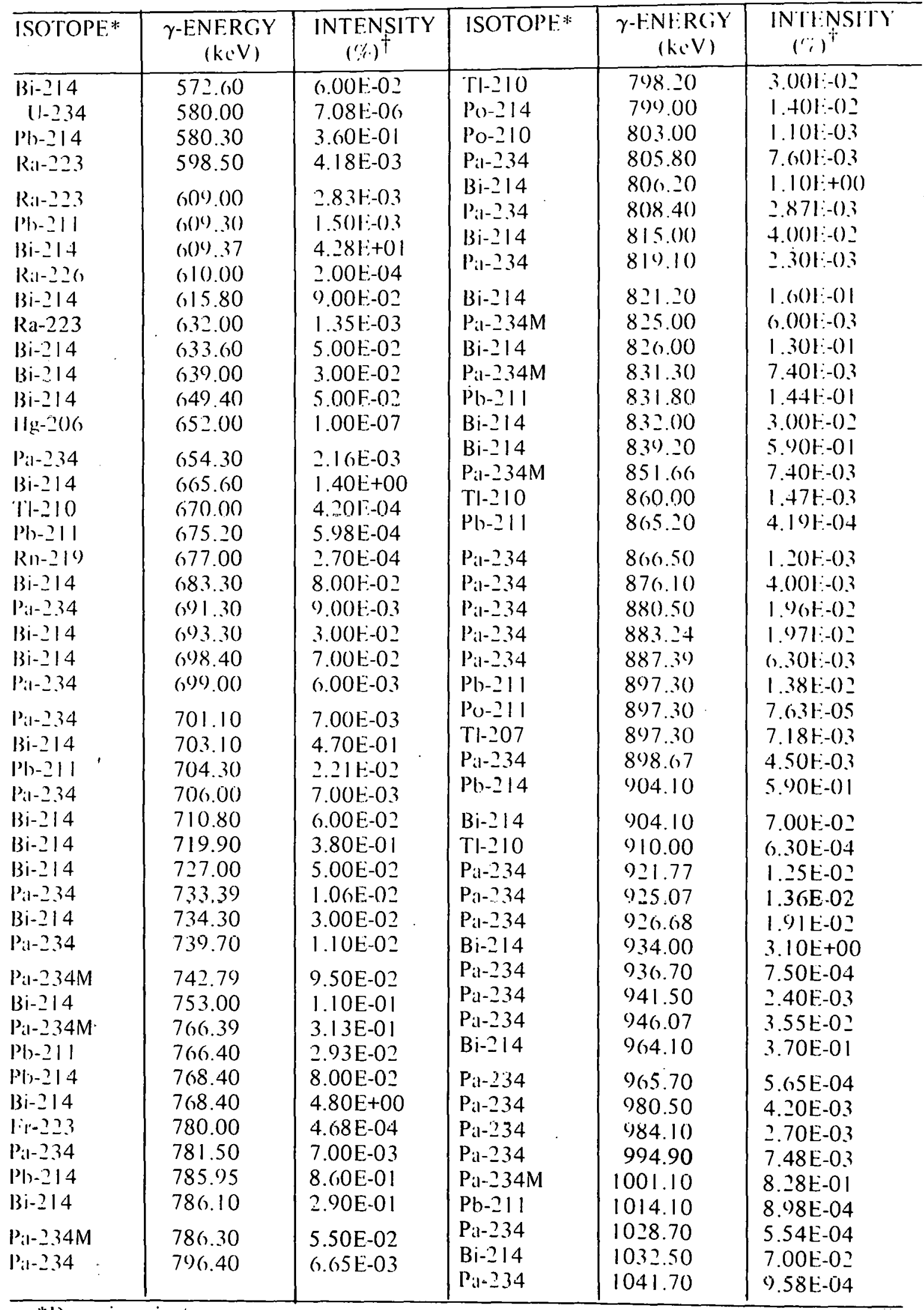

*Decilying isotope

†Absolute intensity per 100 decays of the longest lived parent 


\begin{tabular}{|c|c|c|c|c|c|}
\hline ISOTOPE* & $\begin{array}{c}\gamma \text {-ENERGY } \\
(\mathrm{keV})\end{array}$ & $\begin{array}{l}\text { INTENSITY } \\
(\%)^{\dagger}\end{array}$ & ISOTOPE* & $\begin{array}{c}\gamma \text {-ENERGY } \\
(\mathrm{keV})\end{array}$ & $\begin{array}{l}\text { INTENSITY } \\
(\%)^{\dagger}\end{array}$ \\
\hline $\mathrm{Pa}-234$ & 1044.30 & $7.46 \mathrm{E}-04$ & Pa-234M & 1510.32 & $1.30 \mathrm{E}-02$ \\
\hline $\begin{array}{l}\text { Bi-214 } \\
\text { Tl-210 } \\
\text { Pa-234 }\end{array}$ & $\begin{array}{l}1052.00 \\
1060.00 \\
1061.86\end{array}$ & $\begin{array}{l}3.30 \mathrm{E}-01 \\
2.52 \mathrm{E}-03 \\
2.40 \mathrm{E}-03\end{array}$ & $\begin{array}{l}\mathrm{Pa}-234 \mathrm{M} \\
\mathrm{Bi}-214 \\
\mathrm{~T} 1-210\end{array}$ & $\begin{array}{l}1527.25 \\
1538.70 \\
1540.00\end{array}$ & $\begin{array}{l}2.18 \mathrm{E}-03 \\
5.30 \mathrm{E}-01 \\
4.20 \mathrm{E}-04\end{array}$ \\
\hline $\mathrm{Bi}-214$ & 1070.00 & $2.60 \mathrm{E}-01$ & Bi-214 & 1543.30 & $3.40 \mathrm{E}-01$ \\
\hline $\mathrm{Pb}-211$ & 1080.00 & 4.79E-04 & $\mathrm{Pa}-234$ & 1548.24 & $1.40 \mathrm{E}-03$ \\
\hline $\mathrm{Pa}-234$ & 1083.70 & $1.60 \mathrm{E}-03$ & $\mathrm{~Pa}-234 \mathrm{M}$ & 1553.80 & 8.20E-03 \\
\hline $\mathrm{Bi}-214$ & 1104.00 & $1.60 \mathrm{E}-01$ & $\mathrm{~Pa}-234$ & 1558.90 & $7.00 \mathrm{E}-04$ \\
\hline $\mathrm{Pb}-211$ & 1109.10 & $4.85 \mathrm{E}-03$ & $\mathrm{~Pa}-234 \mathrm{M}$ & 1570.80 & $1.05 \mathrm{E}-03$ \\
\hline Tl-210 & 1110.00 & $1.47 \mathrm{E}-03$ & $\mathrm{Bi}-214$ & 1583.30 & $7.30 \mathrm{E}-01$ \\
\hline $\mathrm{Bi}-214$ & 1120.40 & $1.50 \mathrm{E}+01$ & $\mathrm{Tl}-210$ & 1590.00 & 4.20E-04 \\
\hline $\mathrm{Pa}-234$ & 1122.00 & $6.53 \mathrm{E}-04$ & $\mathrm{~Pa}-234$ & 1593.20 & $2.65 \mathrm{E}-03$ \\
\hline $\mathrm{Pa}-234 \mathrm{M}$ & 1125.10 & 4.70E-03 & Pa-234M & 1593.20 & $3.40 \mathrm{E}-04$ \\
\hline $\mathrm{Bi}-214$ & 1133.80 & $2.50 \mathrm{E}-01$ & $\mathrm{Bi}-214$ & 1594.80 & $3.00 \mathrm{E}-01$ \\
\hline $\mathrm{Pa}-234$ & 1151.10 & $3.90 \mathrm{E}-04$ & $\mathrm{Bi}-214$ & 1599.50 & $3.40 \mathrm{E}-01$ \\
\hline $\mathrm{Bi}-214$ & 1155.30 & $1.70 \mathrm{E}+00$ & $\mathrm{~Pa}-234$ & 1638.10 & $3.80 \mathrm{E}-04$ \\
\hline $\mathrm{Bi}-214$ & 1172.90 & $3.00 \mathrm{E}-02$ & $\mathrm{~T} 1-210$ & 1650.00 & $4.20 \mathrm{E}-04$ \\
\hline $\mathrm{Pa}-234 \mathrm{M}$ & 1193.76 & $1.34 \mathrm{E}-03$ & $\mathrm{~Pa}-234$ & 1654.10 & $3.30 \mathrm{E}-04$ \\
\hline $\mathrm{Pb}-211$ & 1195.50 & $4.79 \mathrm{E}-04$ & $\mathrm{Bi}-214$ & 1661.40 & $1.16 \mathrm{E}+00$ \\
\hline $\mathrm{Bi}-214$ & 1207.80 & $4.70 \mathrm{E}-01$ & $\mathrm{~Pa}-234$ & 1668.40 & $1.20 \mathrm{E}-03$ \\
\hline $\mathrm{Tl}-210$ & 1210.00 & $3.57 \mathrm{E}-03$ & $\mathrm{Bi}-214$ & 1684.10 & $2.40 \mathrm{E}-01$ \\
\hline $\mathrm{Pa}-234$ & 1220.10 & $8.75 \mathrm{E}-04$ & $\mathrm{~Pa}-234$ & 1685.80 & $2.97 \mathrm{E}-04$ \\
\hline $\mathrm{Pa}-234 \mathrm{M}$ & 1237.26 & $4.90 \mathrm{E}-03$ & Pa-234 & 1694.30 & $1.28 \mathrm{E}-03$ \\
\hline $\mathrm{Bi}-214$ & 1238.20 & $6.10 \mathrm{E}+00$ & $\mathrm{~Pa}-234$ & 1716.50 & $1.94 \mathrm{E}-04$ \\
\hline $\mathrm{Pb}-211$ & 1270.00 & $4.79 E-04$ & $\mathrm{Bi}-214$ & 1729.80 & $3.20 \mathrm{E}+00$ \\
\hline$B i-214$ & 1281.00 & $1.50 \mathrm{E}+00$ & Pa-234M & 1737.91 & $2.12 \mathrm{E}-02$ \\
\hline $\mathrm{Pa}-234$ & 1292.70 & 8.60E-04 & Pa-234 & 1750.20 & $1.61 \mathrm{~F}-04$ \\
\hline$B i-214$ & 1303.80 & $1.10 \mathrm{E}-01$ & $P a-234 M$ & 1760.05 & $1.44 \mathrm{l}-03$ \\
\hline $\mathrm{Tl}-210$ & 1310.00 & $4.41 \mathrm{E}-03$ & $\mathrm{Bi}-214$ & 1764.60 & $1.67 \mathrm{E}+01$ \\
\hline $\mathrm{Bi}-214$ & 1317.10 & $7.00 \mathrm{E}-02$ & $\mathrm{~Pa}-234 \mathrm{M}$ & 1765.80 & $7.60 \mathrm{E}-03$ \\
\hline $\mathrm{Pa}-234$ & 1320.50 & $2.90 \mathrm{E}-04$ & $\mathrm{Bi}-214$ & 1782.10 & $1.50 \mathrm{E}-02$ \\
\hline $\mathrm{Pa}-234$ & 1352.90 & $2.24 \mathrm{E}-03$ & $\mathrm{~Pa}-234 \mathrm{M}$ & 1796.70 & $5.70 \mathrm{E}-04$ \\
\hline $\mathrm{Bi}-214$ & 1377.70 & $4.30 \mathrm{E}+00$ & $\mathrm{~Pa}-234 \mathrm{M}$ & 1809.25 & $3.70 \mathrm{E}-03$ \\
\hline $\mathrm{Bi}-214$ & 1385.40 & 8.00E-01 & $\mathrm{Pa}-234$ & 1819.80 & $8.55 \mathrm{E}-04$ \\
\hline $\mathrm{Pa}-234 \mathrm{M}$ & 1393.50 & $3.70 \mathrm{E}-03$ & $\mathrm{~Pa}-234 \mathrm{M}$ & 1831.48 & $1.75 \mathrm{E}-02$ \\
\hline Bi-214 & 1401.60 & $1.50 \mathrm{E}+00$ & $\mathrm{Bi}-214$ & 1838.60 & $3.70 \mathrm{E}-01$ \\
\hline$B i-214$ & 1408.00 & $2.60 \mathrm{E}+00$ & $\mathrm{Bi}-214$ & 1847.60 & $2.30 \mathrm{~F}+00$ \\
\hline Tl-210 & 1410.00 & $1.05 \mathrm{E}-03$ & Pa-234 & 1863.00 & $1.15 \mathrm{E}-02$ \\
\hline$P_{\mathrm{a} 1}-234 \mathrm{M}$ & 1413.90 & $2.31 \mathrm{E}-03$ & $P a-234 M$ & 1867.48 & $9.151:-03$ \\
\hline $\mathrm{Bi}-214$ & 1415.70 & $3.00 \mathrm{E}-02$ & $\mathrm{Bi}-214$ & 1873.40 & 2.20E-01 \\
\hline $\mathrm{Pa}-234 \mathrm{M}$ & 1434.27 & 9.00 E-03 & $\mathrm{Pa}-234$ & 1874.77 & $7.80 \mathrm{E}-03$ \\
\hline $\mathrm{P}_{\mathrm{al}-234}$ & 1445.80 & $4.00 \mathrm{E}-04$ & $\mathrm{~Pa}-234 \mathrm{M}$ & 1877.00 & $1.931:-03$ \\
\hline $\mathrm{Bi}-214$ & 1447.00 & $3.00 \mathrm{E}-02$ & $B i-214$ & 1890.40 & $1.001:-01$ \\
\hline$P: 1-234$ & 1452.60 & $9.50 \mathrm{E}-04$ & P:a-234 & 1800.50 & $2 .(0)(01 ;-() 4$ \\
\hline $\mathrm{Bi}-214$ & 1479.20 & $5.00 \mathrm{E}-02$ & Pal-2.34M & 1893.65 & $2.1 .31:-0.3$ \\
\hline TI-210 & 1490.00 & $4.20 \mathrm{E}-04$ & $\mathrm{Bi}-214$ & 1890.70 & $1.801:-01$ \\
\hline$B i-214$ & 1509.30 & $2.20 \mathrm{E}+00$ & $P_{a-234 M}$ & 1911.21 & 0. $10 \mathrm{E}-03$ \\
\hline
\end{tabular}

*Decaying isotope

†Absolute intensity per 100 decitys of the longest lived parent 


\begin{tabular}{|c|c|c|c|c|c|}
\hline ISOTOPI: & $\begin{array}{c}\gamma \text {-FNERGY } \\
(\mathrm{keV})\end{array}$ & $\begin{array}{l}\text { INTENSITY } \\
(1 / 1)^{\dagger}\end{array}$ & ISOTOPE* & $\begin{array}{c}\gamma \text {-ENERGY } \\
(\mathrm{keV})\end{array}$ & $\begin{array}{l}\text { INTENSITY } \\
(\%)^{\dagger}\end{array}$ \\
\hline$\overline{P: 1-2.34}$ & 1925.78 & $5.70 \mathrm{E}-04$ & $\mathrm{Bi}-214$ & 2699.50 & $5.00 \mathrm{E}-03$ \\
\hline$B \mathrm{Bi}-2 \mathrm{I}$ & 1936.00 & $5.001:-02$ & $\mathrm{Bi}-214$ & 2719.40 & $1.50 \mathrm{E}-0.3$ \\
\hline$P_{1}-2.34 M$ & 19.37 .00 & $2.87 \mathrm{E}-03$ & $\mathrm{Bi}-214$ & 2770.30 & $2.60 \mathrm{E}-02$ \\
\hline$P: 1-234 \mathrm{M}$ & 1969.04 & 4.00E-04 & $\mathrm{Bi}-214$ & 2786.10 & $5.00 \mathrm{E}-03$ \\
\hline$|3 i-2| 4$ & 1994.70 & 5.00E-03 & $\mathrm{Bi}-214$ & $2827.0(0)$ & $2.101:-03$ \\
\hline $11-210$ & 2010.00 & $1.47 \mathrm{E}-(0.3$ & $B i-214$ & 2880.70 & $8.00 \mathrm{E}-03$ \\
\hline$|3 i-2| 4$ & 2011.00 & $3.70 \mathrm{E}-02$ & $\mathrm{Bi}-214$ & 2893.70 & $6.00 \mathrm{E}-03$ \\
\hline$|3 i-2| 4$ & 2016.00 & $1.60 \mathrm{E}-02$ & $\mathrm{Bi}-214$ & 2918.00 & $1.50 E-03$ \\
\hline$P_{11-234}$ & 2022.50 & $1.87 \mathrm{E}-04$ & $\mathrm{Bi}-214$ & 2922.20 & 1.60E-02 \\
\hline$P: 1-234$ & 2041.00 & 8.97E-05 & $\mathrm{Bi}-214$ & 2940.00 & 1.50E-03 \\
\hline$B i-214$ & 2053.20 & $7.00 \mathrm{E}-02$ & $\mathrm{Bi}-214$ & 2963.00 & $1.00 \mathrm{E}-03$ \\
\hline$P_{11-2.34}$ & 2065.50 & $8.00 \mathrm{E}-05$ & $\mathrm{Bi}-214$ & 2979.00 & $1.40 \mathrm{E}-02$ \\
\hline$B \mathrm{~B}-214$ & 2084.20 & $1.00 \mathrm{E}-02$ & $\mathrm{Bi}-214$ & 2988.70 & $1.00 \mathrm{E}-03$ \\
\hline $\mathrm{Bi}-214$ & 2089.70 & $5.00 \mathrm{E}-02$ & $\begin{array}{l}\mathrm{B} \mathrm{i}-2 \\
\mathrm{Bi}-2 \mathrm{l}\end{array}$ & 3000.10 & $1.00 \mathrm{E}-02$ \\
\hline $\mathrm{T} 1-210$ & 2090.00 & $1.05 \mathrm{E}-03$ & $\begin{array}{l}\mathrm{Bl}-214 \\
\mathrm{Bi}-214\end{array}$ & 3054.00 & $2.10 \mathrm{E}-02$ \\
\hline $\mathrm{Bi}-214$ & 2110.40 & $1.00 \mathrm{E}-01$ & $\begin{array}{l}\mathrm{Bl}-214 \\
\mathrm{Bi}-214\end{array}$ & 3081.70 & $5.00 \mathrm{E}-03$ \\
\hline $\mathrm{Bi}-214$ & 2118.70 & $1.30 E+00$ & Bi-214 & 3142.50 & $1.00 E-03$ \\
\hline$P: 1-234$ & 2136.40 & 8.25E-05 & $\mathrm{Bi}-214$ & 3162.20 & $5.00 \mathrm{E}-04$ \\
\hline$B i-214$ & 2147.70 & 1.20E-02 & $\mathrm{Bi}-214$ & 3182.80 & $5.00 \mathrm{E}-04$ \\
\hline$B i-214$ & 2192.50 & $7.00 F-0 ?$ & & & \\
\hline$B i-214$ & 2204.30 & $5.30 \mathrm{E}+00$ & & & \\
\hline$B i-214$ & 2260.00 & $5.00 E-03$ & & & \\
\hline$B i-2 \mid 4$ & 2266.40 & $1.50 \mathrm{E}-02$ & & & \\
\hline$T 1-210$ & 2280.00 & $6.30 \mathrm{E}-04$ & & & \\
\hline$|3 i-2| 4$ & 2293.70 & $3.30 \mathrm{E}-01$ & & & \\
\hline$B i-214$ & 2312.50 & $9.00 \mathrm{E}-03$ & & & \\
\hline $\mathrm{Bi}-214$ & 2331.70 & $2.10 \mathrm{E}-02$ & & & \\
\hline $\mathrm{Bi}-214$ & 2377.20 & $6.00 \mathrm{E}-03$ & & & \\
\hline $\mathrm{TI}-210$ & 2380.00 & $1.68 \mathrm{E}-03$ & & & \\
\hline$B i-214$ & 2423.70 & $6.00 \mathrm{E}-03$ & & & \\
\hline Tl-210 & 2430.00 & $1.89 \mathrm{E}-03$ & & & \\
\hline Bi 214 & 2448.00 & $1.65 \mathrm{E}+00$ & & & \\
\hline$B i-214$ & 2479.00 & $1.60 \mathrm{E}-02$ & & & \\
\hline $\mathrm{Bi}-214$ & 2505.60 & 7.00E-03 & & & \\
\hline $\mathrm{Bi}-214$ & 2695.10 & $3.10 \mathrm{E}-02$ & & & \\
\hline
\end{tabular}

* Decaying isotope

†Absolute intensity per 100 decays of the longest lived parent

\section{APPENDIX Ib: U-235 DECAY SERIES}

The U-235 decay series members are listed in terms of this uranium isotope alone in equilibrium with all its daughters. This situation in never observed in nature. where the U-235/U-238 ratio is found to be constant to within 1-3\%, at a "normal" value of 0.00711 on a weight basis. For equilibrium series studies, a properly aged Ac-227 source could provide the correct assemblage of all its daughter $\gamma$-rays. Addition of the right proportion of isotopically separated U-235 could then provide a synthetic equilibrium sample of all major U-235 series $\gamma$-rays, for a period that is short compared to the 22 -year hall life of Ac-227. 


\section{ISOTOPE}

U-235

$\mathrm{Pa}-231$

Th-231

Ac- 227

Th-227

Ra-223

Fr-223

$\mathrm{Rn}-219$

Po-215

Po-211

$\mathrm{Bi}-211$

$\mathrm{Pb}-211$

Tl-207

\section{REFERENCES}

Gunnink 1971

Lange 1969, De Pinho 1970

Gunnink 1971

Polak 1966

Davidson 1968, Hesselink 1972

Davidson 1970, Krien 1970

Lederer 1967

Davidson 1970, Krien 1970

Lederer 1967

Lederer 1967

Gorodetzky 1968, Hamilton 1968

Gorodetzky 1968, Hamilton 1968

Lederer 1967

\begin{tabular}{|c|c|c|c|c|c|}
\hline ISOTOPE* & $\begin{array}{c}\gamma \text {-ENERGY } \\
(\mathrm{keV})\end{array}$ & $\begin{array}{l}\text { INTENSITY } \\
\left(\%(1){ }^{\dagger}\right.\end{array}$ & ISOTOPE* & $\begin{array}{c}\gamma \text {-ENERGY } \\
(\mathrm{keV})\end{array}$ & $\begin{array}{l}\text { INTENSITY } \\
(1 / \%)^{\dagger}\end{array}$ \\
\hline$\overline{P a-231}$ & 25.54 & $2.70 \mathrm{E}-03$ & $\overline{\mathrm{Pa}}-231$ & 54.61 & $2.431:-03$ \\
\hline$P a-231$ & 27.35 & $2.79 \mathrm{E}-01$ & Th-227 & 56.10 & $1.97 \mathrm{~b}-03$ \\
\hline Pa-23i & 29.95 & $2.76 \mathrm{E}-03$ & $\mathrm{~Pa}-231$ & 56.76 & $1.801:-(04$ \\
\hline$P: 1-231$ & 31.00 & 2.70E-04 & $P a-231$ & 57.19 & $1.171:-0.3$ \\
\hline Pat-231 & 31.54 & 2.10E-04 & Th-231 & 58.55 & 4.2(0):-(0) \\
\hline$P a-231$ & 35.82 & $4.80 E-04$ & Th-227 & 59.60 & $8.88 \mathrm{i}-03$ \\
\hline $\mathrm{Pa}-231$ & 38.20 & $4.47 \mathrm{E}-03$ & $\mathrm{~Pa}-231$ & 60.50 & 2.10E-04 \\
\hline$P a-231$ & 39.57 & $4.20 \mathrm{E}-05$ & Th-227 & 61.50 & unknown \\
\hline$P a 1-231$ & 39.97 & $3.60 \mathrm{E}-04$ & Th-2 27 & 62.00 & unknown \\
\hline Th-227 & 40.10 & unknown & Th-227 & 62.50 & $2.47 \mathrm{E}-01$ \\
\hline Th-227 & 42.20 & $7.90 \mathrm{E}-02$ & Th-227 & 62.70 & $8.88 \mathrm{E}-03$ \\
\hline$P a-231$ & 42.48 & $1.80 \mathrm{E}-04$ & $P a-231$ & 63.67 & $1.50 \mathrm{E}-03$ \\
\hline Th-231 & 42.81 & $5.40 \mathrm{E}-02$ & Th-227 & 64.50 & $2.76 \mathrm{E}-02$ \\
\hline $\mathrm{Pa}-231$ & 43.05 & 2.10E-04 & $\mathrm{Pb}-211$ & 65.40 & $3.99 \mathrm{E}-02$ \\
\hline Th-227 & 43.50 & $2.37 \mathrm{E}-01$ & Th-227 & 66.20 & $5.92 \mathrm{E}-03$ \\
\hline Th-227 & 43.80 & $4.94 \mathrm{E}-02$ & Th-227 & 66.40 & $6.91 E-03$ \\
\hline Th-227 & 44.10 & $6.91 \mathrm{E}-03$ & Th-2 27 & 68.70 & $1.97 \mathrm{E}-03$ \\
\hline$P a-231$ & 44.16 & $1.80 \mathrm{E}-03$ & Th-227 & 68.80 & $2.761:-02$ \\
\hline Th-227 & 44.30 & $1.28 \mathrm{E}-02$ & Th-227 & 69.80 & $8.88 \mathrm{E}-03$ \\
\hline Pal-231 & 40.37 & $6.24 \mathrm{E}-03$ & $A c-227$ & 70.00 & $1.56 \mathrm{~F}-(1) 2$ \\
\hline Th-227 & 48.30 & unknown & $\mathrm{Pa}-231$ & 70.50 & 2.10K:-04 \\
\hline$T h-227$ & 48.50 & $4.44 \mathrm{E}-02$ & $P a-231$ & 71.90 & $(.001:-0.5$ \\
\hline$T h_{1}-227$ & 49.80 & i.97-01 & $P: 1-231$ & 72.50 & $1.201 \div-(04$ \\
\hline Fr -223 & 49.80 & $5.20 \mathrm{E}-01$ & Th-231 & 72.76 & $2.20 t-(0)$ \\
\hline Th-227 & 50.20 & $8.59 E+00$ & Th-227 & 72.90 & $7.901:-03$ \\
\hline Th-227 & 50.70 & $1.58 \mathrm{E}-02$ & Th-227 & 73.70 & $1.681:-02$ \\
\hline$P a-231$ & 50.98 & 4.20E-05 & $\mathrm{Pa}-231$ & 74.18 & $7.50 \%-(04$ \\
\hline Th-227 & 51.20 & unknown & Th-227 & 75.30 & $8.881:-0.3$ \\
\hline$P a-231$ & 52.74 & $2.55 \mathrm{E}-03$ & $\mathrm{~Pa}-231$ & 77.36 & $2.041-(0.3$ \\
\hline Th-227 & 54.20 & unknown & Th-227 & 79.70 & $1.78 E+00$ \\
\hline
\end{tabular}

*Decaying isotope

tAbsolute intensity per 100 decalys of the longest lived palrent 
224 High-Resolution Spectrometry Of Natural Series

\begin{tabular}{|c|c|c|c|c|c|}
\hline ISOTOPE* & $\begin{array}{c}\gamma \text {-ENERGY } \\
(\mathrm{keV})\end{array}$ & $\begin{array}{l}\text { INTENSITY } \\
(\%)^{\dagger}\end{array}$ & ISOTOPE* & $\begin{array}{c}\gamma \text {-ENERGY } \\
(\mathrm{keV})\end{array}$ & $\begin{array}{c}\text { INTENSITY } \\
(\%)^{\dagger}\end{array}$ \\
\hline$\overline{F r}-223$ & 80.00 & $1.69 \mathrm{E}-01$ & Th-227 & 124.40 & $1.97 \mathrm{E}-0.3$ \\
\hline$|T h-2.3|$ & 81.21 & $7.44 \mathrm{E}-01$ & Pat-231 & 124.60 & $1.501:-04$ \\
\hline||$h-2.3 \mid$ & 82.06 & $3.41 \mathrm{E}-01$ & Th-227 & 124.70 & $2.961:-03$ \\
\hline$T h-231$ & 84.20 & $5.60 E+00$ & Th-231 & 124.95 & $5.34 \mathrm{E}-02$ \\
\hline$A c-227$ & 85.60 & $3.51 \mathrm{E}-02$ & $\mathrm{Rn}-219$ & 130.70 & $1.04 \mathrm{E}-01$ \\
\hline Th-227 & 89.90 & unknown & $A c-227$ & 133.50 & $2.60 \mathrm{E}-03$ \\
\hline Th-231 & $89.93^{\circ}$ & 8.40E-0I & Th-231 & 134.03 & $2.18 \mathrm{E}-02$ \\
\hline U-235 & 89.96 & $2.45 \mathrm{E}+00$ & Th-227 & 134.20 & 2.96E-03 \\
\hline Th-231 & 92.27 & 3.80E-01 & Th-231 & 135.69 & $7.17 \mathrm{E}-02$ \\
\hline Th-231 & 92.94 & $6.60 \mathrm{E}-02$ & Fr-223 & 136.00 & $5.20 \mathrm{E}-03$ \\
\hline U-235 & 93.35 & $4.00 E+00$ & Th-231 & 136.80 & $3.00 \mathrm{E}-03$ \\
\hline Th-227 & 94.00 & $1.33 \mathrm{E}+00$ & Th-227 & 140.50 & $3.16 \mathrm{E}-02$ \\
\hline Th-227 & 95.00 & unknown & U-235 & 140.75 & $2.08 \mathrm{E}-01$ \\
\hline$P b-2 \mid 1$ & 95.00 & $1.33 \mathrm{E}-02$ & Th-227 & 141.20 & $6.42 \mathrm{E}-02$ \\
\hline Th-231 & 95.85 & $5.60 \mathrm{E}-01$ & U-235 & 143.77 & $1.07 \mathrm{E}+01$ \\
\hline Th-227 & 96.10 & 4.44E-02 & $\mathrm{Ra}-223$ & 144.19 & $3.13 E+00$ \\
\hline Pal-231 & 96.88 & $2.64 \mathrm{E}-03$ & $\mathrm{~Pa}-231$. & 144.50 & $3.60 \mathrm{E}-04$ \\
\hline Th-231 & 99.27 & $1.18 \mathrm{E}-01$ & Th-231 & 145.13 & $5.60 \mathrm{E}-03$ \\
\hline Ac-227 & 99.50 & $2.60 \mathrm{E}-02$ & Th-23l & 145.96 & $2.80 \mathrm{E}-02$ \\
\hline Th-227 & 99.50 & unknown & Ac- -227 & 147.00 & $7.80 \mathrm{E}-03$ \\
\hline Th-2227 & 99.70 & unknown & Th-227 & 149.80 & $1.78 \mathrm{E}-02$ \\
\hline Fr-223 & 100.00 & $1.30 \mathrm{E}-02$ & Ra-223 & 154.18 & $5.23 E+00$ \\
\hline Th. 227 & 100.40 & 7.90E-02 & Ra-223 & 158.62 & $7.60 \mathrm{E}-01$ \\
\hline P':1-2.31 & 100.92 & $9.60 \mathrm{E}-04$ & $A c-227$ & 160.00 & $1.82 \mathrm{E}-02$ \\
\hline$|7|-23 \mid$ & 102.29 & $3.80 \mathrm{E}-01$ & Th-227 & 162.20 & $5.92 E-03$ \\
\hline Th-227 & 102.50 & unknown & Th-231 & 163.16 & $1.39 E-01$ \\
\hline Pa-231 & 102.60 & 6.00E-04 & U-235 & 163.37 & $4.85 E+00$ \\
\hline U-235 & 104.82 & $4.56 \mathrm{E}-01$ & Th- 227 & 168.20 & $1.38 \mathrm{E}-02$ \\
\hline $\mathrm{U}-235$ & 105.61 & $9.10 \mathrm{E}-01$ & Fr -223 & 170.00 & $3.12 \mathrm{E}-03$ \\
\hline$A c-227$ & 106.50 & $1.30 \mathrm{E}-03$ & Th-227 & 170.10 & $2.96 \mathrm{E}-03$ \\
\hline Rat-223 & 106.80 & 2.20E-02 & Th-227 & 171.40 & unknown \\
\hline Th-231 & 107.60 & $6.80 \mathrm{E}-02$ & $A c-227$ & 172.00 & $5.20 \mathrm{E}-03$ \\
\hline Th-227 & 108.00 & $6.91 \mathrm{E}-03$ & Th-227 & 173.40 & $1.09 \mathrm{E}-02$ \\
\hline Th-231 & 108.44 & $1.31 E+00$ & Th-227 & 175.80 & $1.78 \mathrm{E}-02$ \\
\hline Th-227 & 109.60 & $5.92 \mathrm{E}-03$ & $\mathrm{Ra}-223$ & 176.00 & 2.10E-02 \\
\hline Th-227 & 110.60 & 1.97E-03 & $\mathrm{Ra}-223$ & 177.30 & $2.10 \mathrm{E}-02$ \\
\hline Ra-223 & 110.80 & $5.60 \mathrm{E}-02$ & $\mathrm{Ra}-223$ & 179.60 & $1.50 \mathrm{E}-01$ \\
\hline Th-23l & 111.54 & $5.45 \mathrm{E}-02$ & U-235 & 182.57 & $3.60 \mathrm{E}-01$ \\
\hline Th-231 & 112.48 & 1.94E-02 & Th-227 & 184.70 & $2.66 \mathrm{E}-02$ \\
\hline Th-227 & 112.60 & $7.90 \mathrm{E}-03$ & U-235 & 185.72 & $5.61 E+01$ \\
\hline $7 h_{1}-227$ & 113.10 & $5.33 \mathrm{E}-01$ & Ac- 227 & 190.00 & $6.50 \mathrm{E}-04$ \\
\hline Th-231 & 116.83 & $2.00 E-02$ & Fr-223 & 190.00 & unknown \\
\hline Th-227 & 117.00 & $1.58 \mathrm{E}-01$ & $\mathrm{Ra}-223$ & 193.00 & $1.00 \mathrm{E}-0.2$ \\
\hline Th-227 & 117.50 & 1.18E-02 & U-235 & 194.94 & $6.15 \mathrm{E}-01$ \\
\hline Ac- -227 & 121.50 & $\begin{array}{l}5.20 \mathrm{E}-03 \\
133 \mathrm{~F}+00\end{array}$ & Th-227 & 197.60 & $9.87 \mathrm{E}-03$ \\
\hline Ra-223: & $\begin{array}{l}122.30 \\
12360\end{array}$ & $\begin{array}{l}1.33 \mathrm{E}+00 \\
7.90 \mathrm{~F}-03\end{array}$ & $\mathrm{~Pa}-231$ & 199.00 & $1.80 \mathrm{E}-04$ \\
\hline $1 \mathrm{~h}-221$ & 123.60 & $7.90 \mathrm{E}-03$ & Th-227 & 200.50 & $4.93 E-03$ \\
\hline
\end{tabular}

*Decaying isotope

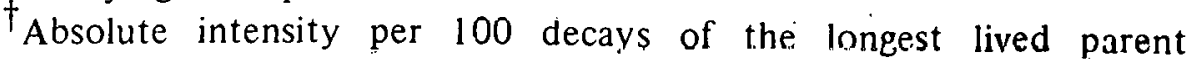




\begin{tabular}{|c|c|c|c|c|c|}
\hline ISOTOPE* & $\begin{array}{c}\gamma \text {-ENERGY } \\
(\mathrm{keV})\end{array}$ & $\begin{array}{l}\text { INTENSITY } \\
(\%)^{\dagger}\end{array}$ & ISOTOPE* & $\begin{array}{c}\gamma \text {-ENERGY } \\
(\mathrm{keV})\end{array}$ & $\begin{array}{l}\text { INTINSITY } \\
\left(\%(\%)^{\dagger}\right.\end{array}$ \\
\hline Th-227 & 201.80 & $2.17 \mathrm{E}-02$ & Th-227 & 273.00 & $4.841:-01$ \\
\hline U-235 & 202.10 & $1.07 \mathrm{E}+00$ & $P a-231$ & 273.08 & $1.741-(03$ \\
\hline Th-227 & 202.50 & $5.92 \mathrm{E}-03$ & U-235 & 275.34 & $2.691-02$ \\
\hline Th-227 & 204.20 & $2.27 \mathrm{E}-01$ & $\mathrm{~Pa}-231$ & 276.99 & $2.01 \mathrm{E}-03$ \\
\hline Fr-223 & 205.00 & 1.04E-02 & Thl-2 27 & 279.70 & $8.88 \mathrm{E}-02$ \\
\hline Th-227 & 205.20 & $1.68 \mathrm{E}-01$ & Th-227 & 281.00 & unknown \\
\hline U-235 & 205.33 & $4.87 \mathrm{E}+00$ & Th-227 & 281.40 & $1.48 \mathrm{E}-01$ \\
\hline Th-227 & 206.10 & $2.57 \mathrm{E}-01$ & $\mathrm{~Pa}-231$ & 283.56 & $4.71 \mathrm{E}-02$ \\
\hline Th-227 & 206.40 & $3.95 \mathrm{E}-03$ & Th-227 & 284.30 & $2.47 \mathrm{E}-02$ \\
\hline Th-227 & 210.60 & $1.24 \mathrm{E}+00$ & Th-227 & 285.60 & $5.431 ;-(02$ \\
\hline Th- 227 & 212.60 & 8.39E-02 & Th-227 & 286.20 & $1.63 \mathrm{E}+00$ \\
\hline Th-227 & 212.70 & $1.68 \mathrm{E}-02$ & Pal-231 & 286.55 & $2.70 \mathrm{r}-04$ \\
\hline U-235 & 215.35 & $2.75 \mathrm{E}-02$ & $\mathrm{Ra}-2 \geq 3$ & 288.40 & $1.47 \mathrm{E}-01$ \\
\hline Th-227 & 218.20 & $5.43 \mathrm{E}-02$ & Th-227 & 289.60 & $3.951:-03$ \\
\hline Th- 227 & 219.00 & $4.44 \mathrm{E}-02$ & Fr -223 & 290.00 & $7.80 \mathrm{H}-03$ \\
\hline Rn-219 & 222.00 & $2.80 \mathrm{E}-02$ & $\mathrm{U}-235$ & 291.63 & $2.00 \mathrm{t}-02$ \\
\hline Th-227 & 224.70 & $1.48 \mathrm{E}-02$ & Th-227 & 292.30 & $5.43 \mathrm{H}-02$ \\
\hline Th- 227 & 230.40 & unk nown & Rn-219 & 294.00 & 5.90F:-02 \\
\hline U-235 & 233.54 & $2.75 \mathrm{E}-02$ & Th-2227 & 296.60 & $3.851 \%-01$ \\
\hline$F_{r}-223$ & 234.00 & $4.68 \mathrm{H}-02$ & P:1-231 & 299.94 & $0.781:-0) 2$ \\
\hline Th-2 27 & 2.34 .90 & $5.721:-(0) \mid$ & Th-2 27 & 300.00 & $1.871:+00$ \\
\hline Th-2?7 & 236.00 & $1.14 \mathrm{E}+0 \mid$ & Th1-227 & 300.30 & $2.7(11:-01$ \\
\hline U-2.35 & 240.93 & (6.40E:-02 & P:1-231 & 302.52 & 7.021:-(1)2 \\
\hline Pal-231 & 242.20 & 2.40E-04 & Th-2 27 & 304.40 & $1.33 \mathrm{~F}+00$ \\
\hline$P a-231$ & 243.00 & $1.02 \mathrm{E}-03$ & Th-227 & 308.50 & $1.48 \mathrm{H}-02$ \\
\hline$P a-231$ & 245.40 & 2.10E-04 & Pa1-231 & 310.00 & 4.20k-05 \\
\hline Pa-231 & 246.00 & $3.00 \mathrm{E}-05$ & Th-227 & 312.60 & $5.13 \mathrm{E}-01$ \\
\hline Th- 227 & 246.40 & $1.18 \mathrm{E}-02$ & Pa-231 & 312.88 & $2.85 \mathrm{~F}-03$ \\
\hline U- -235 & 246.88 & 5.20E-02 & $\mathrm{Pb}-211$ & 313.60 & $1.331:-02$ \\
\hline Th-227 & 249.60 & $6.91 \mathrm{E}-03$ & Th-227 & 314.80 & $5.33 \mathrm{E}-01$ \\
\hline Th-227 & 250.20 & $2.76 \mathrm{E}-01$ & Th-227 & 314.80 & $2.47 \mathrm{~F}-02$ \\
\hline Th-227 & 250.40 & $6.91 \mathrm{E}-02$ & Th-227 & 318.80 & $5.92:-03$ \\
\hline Rat-223 & 251.70 & $5.70 \mathrm{E}-02$ & Th-227 & 319.20 & 1.78t-02 \\
\hline Th-227 & 252.50 & $1.09 \mathrm{E}-01$ & Fr-223 & 320.00 & $1.04 \mathrm{E}-02$ \\
\hline Th-227 & 254.70 & $8.98 \mathrm{E}-01$ & Ral-223 & 323.88 & $3.60 \mathrm{t}+00$ \\
\hline Ril-223 & 255.00 & 5.00E-02 & Th-227 & 325.20 & 4.9.31:-0.3 \\
\hline$P a 1-231$ & 255.78 & $3.03 \mathrm{E}-03$ & Th-227 & 326.20 & $1.971:-0.3$ \\
\hline Th-227 & 250.20 & $6.22 \mathrm{~F}+00$ & $P: 1-231$ & 327.02 & $9.001:-(04$ \\
\hline P:1-231 & 258.40 & 6.)(0):-05 & R:t-22.3 & 328.50 & 1.621:-(0) \\
\hline$P_{11}-231$ & 260.14 & $5.190-0.3$ & P:1-231 & 329.89 & $3.9(0):-02$ \\
\hline Th-2 27 & 262.70 & $9.87 \mathrm{E}-02$ & Th-227 & 329.90 & $2.86 t t+00$ \\
\hline Th-227 & 267.00 & unknown & $\mathrm{Ra}-223$ & 333.80 & $1.24 E-01$ \\
\hline Th-227 & 267.90 & unk nown & Th-227 & 334.40 & $1.14 E+00$ \\
\hline Ral-223 & 269.41 & $1.36 E+01$ & Ra-223 & 338.30 & $2.59 \mathrm{E}+00$ \\
\hline Th-227 & 270.50 & unk nown & Th-227 & 339.80 & unknown \\
\hline Th-227 & 270.70 & $3.16 \mathrm{E}-02$ & $\mathrm{~Pa}-231$ & 340.61 & $4.95 \mathrm{E}-0.03$ \\
\hline Rn-219 & 271.20 & $9.93 E+00$ & Th-227 & 342.50 & $1.881:-01$ \\
\hline
\end{tabular}

* Decaying isotope

†Absolute intensity per 100 decays of the longest lived parent 


\begin{tabular}{|c|c|c|c|c|c|}
\hline ISOTOPE* & $\begin{array}{c}\gamma \text {-ENERGY } \\
(\mathrm{keV})\end{array}$ & $\begin{array}{l}\text { INTENSITY } \\
(\%)^{\dagger}\end{array}$ & ISOTOPE* & $\begin{array}{c}\gamma \text {-ENERGY } \\
(\mathrm{keV})\end{array}$ & $\begin{array}{l}\text { INTENSITY } \\
(\%)^{\dagger}\end{array}$ \\
\hline $\begin{array}{l}\mathrm{Pb}-211 \\
\mathrm{Ra}-223\end{array}$ & $\begin{array}{l}342.70 \\
342.90\end{array}$ & $\begin{array}{l}2.00 \mathrm{E}-02 \\
2.10 \mathrm{E}-01\end{array}$ & $\begin{array}{l}\mathrm{Pa}-231 \\
\mathrm{Rd}-223\end{array}$ & $\begin{array}{l}438.70 \\
444.92 \\
48670\end{array}$ & $\begin{array}{l}4.50 \mathrm{E}-05 \\
1.27 \mathrm{E}+00 \\
5.4 \mathrm{~F}-05\end{array}$ \\
\hline $\begin{array}{r}\text { U-235 } \\
\text { Th-227 } \\
\text { Ra-223 } \\
\text { Th-227 }\end{array}$ & $\begin{array}{l}345.89 \\
346.30 \\
346.80 \\
348.50\end{array}$ & $\begin{array}{l}3.00 \mathrm{E}-02 \\
7.90 \mathrm{E}-03 \\
1.70 \mathrm{E}-01 \\
5.92 \mathrm{E}-03\end{array}$ & $\begin{array}{l}\mathrm{Pa}-231 \\
\mathrm{Ra}-223 \\
\mathrm{~Pa}-231 \\
\mathrm{~Pa}-231\end{array}$ & $\begin{array}{l}486.70 \\
488.00 \\
491.00 \\
501.60\end{array}$ & $\begin{array}{l}5.40 \mathrm{E}-05 \\
1.50 \mathrm{E}-02 \\
1.50 \mathrm{E}-05 \\
1.80 \mathrm{E}-05\end{array}$ \\
\hline Fr-223 & 350.00 & $1.30 \mathrm{E}-03$ & $\mathrm{~Pb}-211$ & 503.60 & $7.98 \mathrm{E}-04$ \\
\hline Th-227 & 350.50 & 7.90E-03 & $\mathrm{Pa}-231$ & 509.00 & $9.00 \mathrm{E}-06$ \\
\hline $\mathrm{Bi}-211$ & 351.10 & $1.33 E+01$ & $\mathrm{~Pa}-231$ & 516.20 & $3.90 \mathrm{E}-05$ \\
\hline Th-227 & 352.60 & $8.88 \mathrm{E}-03$ & $R n-219$ & 516.50 & $2.20 \mathrm{E}-02$ \\
\hline$P \cdot a-231$ & 354.38 & $2.85 \mathrm{E}-03$ & Ra-223 & 527.00 & 7.00E-02 \\
\hline$P: 1-231$ & 356.96 & $5.19 \mathrm{E}-03$ & $\mathrm{~Pa}-231$ & 535.20 & 1.50E-05 \\
\hline $\begin{array}{l}\text { Pa-231 } \\
\text { Ra-223 } \\
\text { Th-227 } \\
\text { laa-231 }\end{array}$ & $\begin{array}{l}359.25 \\
361.50 \\
362.50 \\
363.74\end{array}$ & $\begin{array}{l}2.70 \mathrm{E}-04 \\
5.00 \mathrm{E}-02 \\
3.95 \mathrm{E}-03 \\
2.22 \mathrm{E}-04\end{array}$ & $\begin{array}{l}\mathrm{Pa}-231 \\
\mathrm{Po}-211 \\
\mathrm{~Pa}-231 \\
\mathrm{Ra}-223\end{array}$ & $\begin{array}{l}546.60 \\
569.60 \\
572.10 \\
598.50\end{array}$ & $\begin{array}{l}1.80 \mathrm{E}-05 \\
1.60 \mathrm{E}-03 \\
1.50 \mathrm{E}-05 \\
9.30 \mathrm{E}-02\end{array}$ \\
\hline Th- 227 & 369.40 & $3.95 \mathrm{E}-03$ & $\mathrm{Ra}-223$ & 609.00 & $6.30 \mathrm{E}-02$ \\
\hline Th-227 & 370.90 & $1.97 E-03$ & $\mathrm{~Pb}-211$ & 609.30 & $3.33 \mathrm{E}-02$ \\
\hline$R a t-223$ & 371.50 & $5.40 \mathrm{E}-01$ & $\mathrm{Ra}-223$ & 632.00 & $3.00 \mathrm{E}-02$ \\
\hline $\mathrm{Pa}-231^{\circ}$ & 374.90 & 1.38E-04 & $\mathrm{Pb}-211$ & 675.20 & 1.33E-02 \\
\hline Th-227 & 375.10 & $9.87 \mathrm{E}-04$ & Rn-219 & 677.00 & $6.00 \mathrm{E}-03$ \\
\hline Rad-223 & 376.00 & $1.20 \mathrm{E}-02$ & $\mathrm{~Pb}-211$ & 704.30 & $4.92 \mathrm{E}-\mathrm{O} 1$ \\
\hline $\begin{array}{l}\text { Pal-231 } \\
\text { Th-227 } \\
\text { Ral-223 } \\
\text { Th-227 }\end{array}$ & $\begin{array}{l}379.09 \\
382.40 \\
382.50 \\
383.60\end{array}$ & $\begin{array}{l}1.47 \mathrm{E}-03 \\
5.92 \mathrm{E}-0.3 \\
1.50 \mathrm{E}-02 \\
1.97 \mathrm{E}-03\end{array}$ & $\begin{array}{l}\mathrm{Pb}-211 \\
\mathrm{Fr}-223 \\
\mathrm{~Pb}-211 \\
\mathrm{~Pb}-211\end{array}$ & $\begin{array}{l}766.40 \\
780.00 \\
831.80 \\
865.20\end{array}$ & $\begin{array}{l}6.52 \mathrm{E}-02 \\
1.04 \mathrm{E}-02 \\
3.21 \mathrm{E}+00 \\
9.31 \mathrm{E}-03\end{array}$ \\
\hline$P a-231$ & 384.70 & $1.23 \mathrm{E}-04$ & $\mathrm{~Pb}-211$ & 897.30 & $3.06 \mathrm{E}-01$ \\
\hline$P a-231$ & 387.00 & $1.50 \mathrm{E}-05$ & Po-211 & 897.30 & 1.70E-03 \\
\hline U -235 & 387.81 & $1.20 \mathrm{E}-02$ & $\mathrm{Tl}-207$ & 897.30 & $1.59 \mathrm{E}-01$ \\
\hline$P a-231$ & 391.50 & $2.04 \mathrm{E}-04$ & $\mathrm{~Pb}-211$ & 1014.10 & $2.00 \mathrm{E}-02$ \\
\hline Th-227 & 392.40 & $8.88 \mathrm{E}-03$ & $\mathrm{~Pb}-211$ & 1080.00 & $1.06 \mathrm{E}-02$ \\
\hline $\mathrm{Ru}-223$ & 393.50 & $1.10 \mathrm{E}-02$ & $\mathrm{~Pb}-211$ & 1109.10 & $1.08 \mathrm{E}-01$ \\
\hline$P: a-231$ & 395.50 & $7.80 \mathrm{E}-05$ & $\begin{array}{l}\mathrm{Pb}-2111 \\
\mathrm{~Pb}-211\end{array}$ & $\begin{array}{l}1195.50 \\
1270.00\end{array}$ & $\begin{array}{l}1.06 \mathrm{E}-02 \\
1.06 \mathrm{E}-02\end{array}$ \\
\hline$P a-231$ & 398.10 & 2.79E-04 & & & \\
\hline$R n-219$ & 401.80 & $6.48 \mathrm{E}+00$ & & & \\
\hline Th-227 & 402.50 & $3.95 \mathrm{E}-03$ & & & - \\
\hline$P b=211$ & 404.80 & $3.94 \mathrm{E}+00$ & & & \\
\hline Pa-23I & 407.71 & $1.08 \mathrm{E}-03$ & & & \\
\hline Pa-231 & 410.50 & $5.70 \mathrm{E}-05$ & & & $:$ \\
\hline Th-227 & 415.20 & $9.87 \mathrm{E}-04$ & & & \\
\hline $\mathrm{Ph}-211$ & 426.90 & $1.82 E+00$ & & & \\
\hline $\mathrm{Pb}-211$ & 429.10 & $8.64 \mathrm{E}-03$ & & & \\
\hline$R: a-223$ & 432.00 & $3.00 F-02$ & & & \\
\hline Th-227 & 432.50 & $3.95 \mathrm{E}-03$ & & & \\
\hline Pa-231 & 435.10 & $9.90 \mathrm{E}-05$ & & & \\
\hline Pa-231 & 437.90 & 1.23F--04 & & & \\
\hline
\end{tabular}

*Decaying isotope

${ }^{\dagger}$ Absolute intensity per 100 decays of the longest lived parent 
APPENDIX Ic: TH-232 DECAY SERIES

The Th-232 decay series members are listed for the equilibrium condition. The absolute intensities given here and in Appendix Ia are appropriate to a $\mathrm{Th} / \mathrm{U}$ ratio of 3.2 to 1 , as a consequence of the U-238 and Th-232 half lives. This is a "normal" ratio for natural materials; in effect, these two lists can be used in direct combination for estimation of $\mathrm{Ge}(\mathrm{Li})$ spectrometer response from normal materials.

Experimental data has been converted to the given absolute intensities by use of the following normalizations: all Ac-228 $\gamma$-ray intensities are normalized to $30.0 \%$ abundance for the $911 \mathrm{keV}$ line; the $\mathrm{Bi}-212$ decay branching is $36.0 \%$ to. $\mathrm{Tl}-208$ and $64.0 \%$ to Po-212.

ISOTOPE

$\mathrm{Th}_{\mathbf{7}} 232$

Th-228

Ac- 228

Ra-228

$\mathrm{Ra}-224$

$\mathrm{Rn}-220$

Po-2 16

Po-212

$\mathrm{Bi}-212$

$\mathrm{Pb}-212$

Tl-208

\section{REFERENCES}

Lederer 1967

Lederer 1967, Gunnink 1972

Arnoux 1969, Dalmasso 1971, Ythier 1969

Lederer 1967

Gunnink 1969, Lederer 1967

Lederer 1967

Lederer 1967

Lederer 1967

Gunnink 1969, Gunnink 1972

Gunnink 1969, Gunnink 1972

Gunnink 1969, Gunnink 1972, Pakkanen 1969

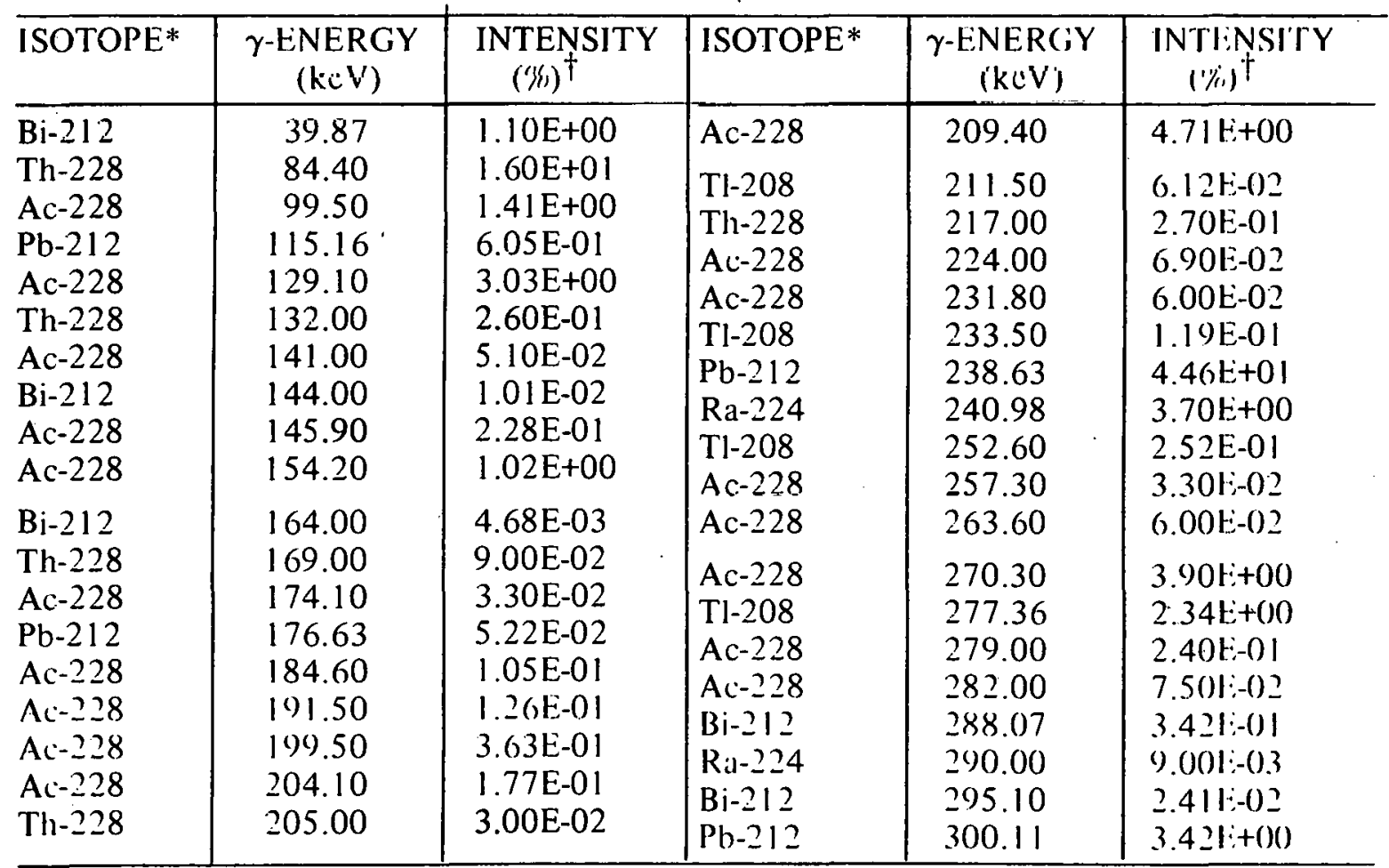

*Decaying isotope

†Absolute intensity per 100 decays of the longest lived parent 


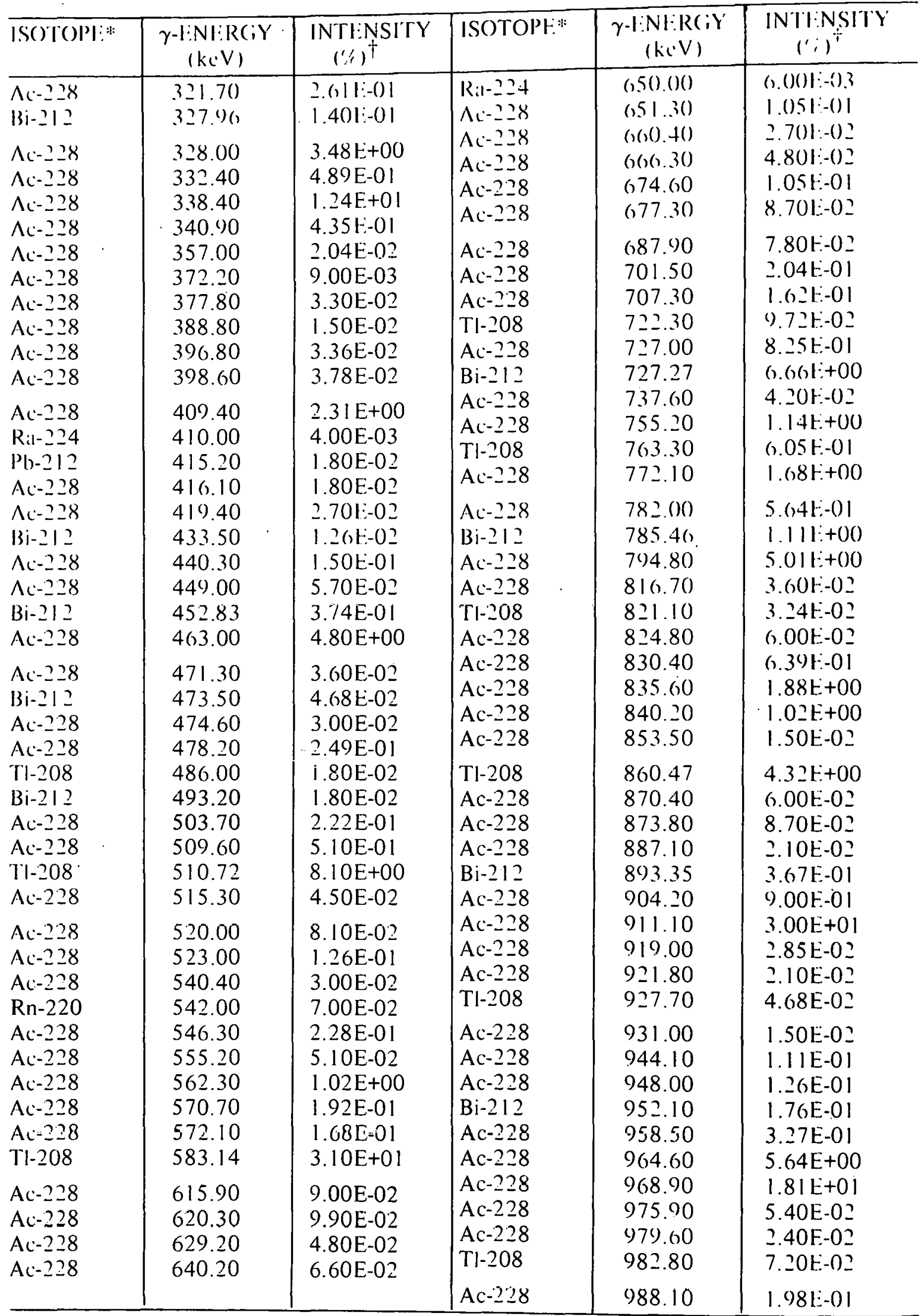

*Decalying isotope

${ }^{\dagger}$ Absolute intensity per 100 decays of the longest lived parent 


\begin{tabular}{|c|c|c|c|c|c|}
\hline $\begin{array}{l}\text { ISOTOPE* } \\
\text {. }\end{array}$ & $\begin{array}{c}\boldsymbol{\gamma} \text {-ENERGY } \\
(\mathrm{keV})\end{array}$ & $\begin{array}{l}\text { INTENSITY } \\
(\%)^{\dagger}\end{array}$ & ISOTOPE* & $\begin{array}{c}\gamma \text {-ENERGY } \\
(\mathrm{keV})\end{array}$ & $\begin{array}{c}\text { INTENSITY } \\
\left((\% /)^{\dagger}\right.\end{array}$ \\
\hline Tl-208 & 1004.00 & $3.60 \mathrm{E}-03$ & $\mathrm{Bi}-212$ & 1620.62 & $1.51 E+00$ \\
\hline Ac-228 & 1016.70 & $2.55 \mathrm{E}-02$ & Ac- 228 & 1624.70 & $3.30 \mathrm{E}-0 \mathrm{I}$ \\
\hline$A c=228$ & 1019.70 & $2.55 \mathrm{E}-02$ & $A c-228$ & 1630.40 & $2.02 E+00$ \\
\hline Ac: 228 & 1033.10 & $2.34 \mathrm{E}-01$ & Ac- 228 & 1638.00 & $5.61 \mathrm{E}-01$ \\
\hline Ac- 228 & 1053.50 & 3.30E-02 & $\begin{array}{l}\text { Ac- } 228 \\
\text { Tl-208 }\end{array}$ & $\begin{array}{l}1030.00 \\
1643.00\end{array}$ & $3.60 \mathrm{E}-03$ \\
\hline Ac-228 & 1065.10 & $1.53 \mathrm{E}-01$ & Ac- 228 & 1666.40 & $2.16 \mathrm{E}-01$ \\
\hline $\mathrm{Bi}-212$ & 1074.00 & $1.58 \mathrm{E}-02$ & $\begin{array}{l}\mathrm{Ac}-228 \\
\mathrm{Ac}-228\end{array}$ & $\begin{array}{l}1000.40 \\
1677.60\end{array}$ & $6.90 \mathrm{E}-02$ \\
\hline $\mathrm{Bi}-212$ & 1078.80 & $5.36 \mathrm{E}-01$ & $\begin{array}{l}\mathrm{Ac}-228 \\
\mathrm{Bi}-212\end{array}$ & 1679.50 & $6.84 \mathrm{E}-02$ \\
\hline T1-208 & 1093.90 & $1.37 \mathrm{E}-01$ & Ac-228 & 1685.90 & $1.08 \mathrm{E}-01$ \\
\hline Ac- 228 & 1095.70 & $1.38 \mathrm{E}-01$ & Ac- 228 & 1702.30 & $6.90 \mathrm{E}-02$ \\
\hline Ac-228 & 1103.40 & $1.80 \mathrm{E}-02$ & Ac- 228 & 1706.50 & $1.35 \mathrm{E}-02$ \\
\hline Ac-228 & 1110.60 & $3.60 \mathrm{E}-01$ & Ac- 228 & 1713.00 & $6.00 \mathrm{E}-03$ \\
\hline Ac-228 & 1117.80 & $6: 30 \mathrm{E}-02$ & Ac-228 & $1724: 30$ & $3.30 \mathrm{E}-02$ \\
\hline Ac- 228 & 1135.60 & $1.26 \mathrm{E}-02$ & Ac- 228 & 1738.30 & 201 E-02 \\
\hline Ac-228 & 1142.70 & $1.05 \mathrm{E}-02$ & Ac- 228 & 1741.10 & $159 E_{-} 02$ \\
\hline Ac- 228 & 1153.60 & $1.65 \mathrm{E}-01$ & Ac- 228 & 1750.80 & $960 \mathrm{E}-03$ \\
\hline Ac- 228 & 1164.60 & $7.80 \mathrm{E}-02$ & Ac-228 & 175790 & $450 \mathrm{E}-02$ \\
\hline Ac- 228 & 1175.30 & 3.00E-02 & Ac- 228 & 1784.40 & $9.90 \mathrm{E}-03$ \\
\hline Ac-228 & 1217.10 & $2.70 \mathrm{E}-02$ & $\mathrm{Bi}-212$ & 1800.00 & $3.60 \mathrm{E}-03$ \\
\hline Ac- 228 & 1247.10 & $5.85 \mathrm{E}-01$ & $\mathrm{Bi}-212$ & 1806.00 & $1.12 \mathrm{E}-01$ \\
\hline Ac-228 & 1249.70 & 6.00E-02 & Ac- 228 & 1823.30 & $5.25 \mathrm{E}-02$ \\
\hline Ac-228 & 1276.80 & 2.10E-02 & Ac- 228 & 1835.60 & $4.80 \mathrm{E}-02$ \\
\hline Tl-208 & 1282.70 & 1.80E-02 & $A c-228$ & 1842.30 & $5.25 \mathrm{E}-02$ \\
\hline Ac- 228 & 1287.50 & $1.23 \mathrm{E}-01$ & Ac- 228 & 1871.10 & $2.70 \mathrm{E}-02$ \\
\hline Ac-228 & 1309.50 & $2.16 \mathrm{E}-02$ & Ac- 228 & 1887.40 & $1.14 \mathrm{E}-01$ \\
\hline$A c=228$ & 1316.10 & 2.19E-02 & Ac- 228 & 1907.80 & $1.20 \mathrm{E}-02$ \\
\hline Ac- 228 & 1348.40 & 1.35E-02 & Ac- 228 & 1930.20 & $2.55 \mathrm{E}-02$ \\
\hline$A c=228$ & 1358.50 & 3.00E-02 & Ac- 228 & 1952.60 & $7.50 \mathrm{E}-02$ \\
\hline Ac-228 & 1374.30 & $1.71 \mathrm{E}-02$ & Ac-228 & 1965.70 & $2.55 \mathrm{E}-02$ \\
\hline T1-208 & 1384.00 & 7.20E-03 & T1-208 & 2614.47 & $3.60 \mathrm{E}+01$ \\
\hline$A c=228$ & 1415.70 & $2.70 \mathrm{E}-02$ & & & \\
\hline Ac- 228 & 1430.90 & 3.30E-02 & & r & \\
\hline$A c=228$ & 1451.50 & 1.89E-02 & & & \\
\hline Ac- 228 & 1459.20 & $1.08 \mathrm{E}+00$ & & & \\
\hline Ac- 228 & 1469.60 & $2.10 \mathrm{E}-02$ & & . & ' \\
\hline Ac- 228 & 1480.40 & $2.10 \mathrm{E}-02$ & & & . \\
\hline $\mathrm{Ac}-228$ & 1495.80 & $1.09 \mathrm{E}+00$ & & & . \\
\hline Ac- 228 & 1501.50 & $6.00 \mathrm{E}-01$ & & & \\
\hline $\mathrm{Bi}-212$ & 1512.75 & $.3 .13 \mathrm{E}-01$ & & & $!$ \\
\hline$A c-228$ & 1528.80 & $6.90 \mathrm{E}-02$ & & & - \\
\hline$A c-228$ & 1537.70 & $5.10 \mathrm{E}-02$ & & & \\
\hline$A c-228$ & 1548.40 & $4.50 \mathrm{E}-02$ & & & \\
\hline$A c-228$ & 1556.90 & $2.10 \mathrm{E}-01$ & & & . \\
\hline$A c-228$ & 1573.10 & $5.70 \mathrm{E}-02$ & & & \\
\hline$A c-228$ & 1580.20 & 7.35E-01 & & & \\
\hline$A c-228$ & 1587.90 & $3.84 \mathrm{E}+00$ & & & \\
\hline Ac- 228 & 1609.30 & $1.20 \mathrm{E}-02$ & & & * \\
\hline
\end{tabular}

*Decaying isotope

${ }^{\dagger}$ Absolute intensity per 100 decays of the longest lived parent 


\section{REFERENCES FOR APPENDIX I}

ARNOUX, M. and A. GIZON. 1969. Compt. Rend., B269, 317.

BORGGiRlEN, J., D. DAVIES, N. J. S. HANSEN, J. PEDERSON, and H. L. NIL:LSEN. 1968. Nucl. Phys., 118:261.

1)ALMASSO, J. and H. MARIA. 1971. Compt. Rend., B272. 905.

DAVIDSON, W. F. and R. D. CONNOR. 1968. Nucl. Phys., 116:342.

DAVIISSON, W. F. and R. D. CONNOR. 1970. Nucl. Phys.. 149:36.3.

DAVIDSON, W. F. and R. D. CONNOR. 1970. Nucl. Phys. 149:385.

FOUCHER, R., J. MERINIS, A. DE PINHO, and M. VALADARES. 1962. Compt. Rend.. B25.5, 1916

IOUCHER, R., J. M. LAGRANGE, O. RAHMOUNI, and H. SERGOlle. 1965. J. Phys. (Paris), 26:430.

corodeTSKY, S., F. A. BECK, T. BYRSKI, and A. KNIPPER. 1968. Nucl. Phys.. $117: 208$.

(IUNNINK, R., J. B. NIDAY, R. P. ANDERSON, and R. A. MEYER. 1969. Lawrence Livermore Laboratory report UCID-15439.

(ilNNINK, R. and I. F. TINNEY, 1971. Lawrence Livermore Laboratory report U('RL.-51080.

GUNNINK, R. 1972. Private communication.

HAMILTON, W. D. and K. E. DAVIES. 1968. Nucl. Phys., 114:577.

IIISSSI:LINK, W. H. A., A. H. WAPSTRA, J. G. KROMME, E. J. HAIGHTON, M. VAN HAMPEN, W. HUTJES, and K. E. M. DIJKMAN. 1972. Nucl. Phys., 191:283.

HYDE, E. K., I. PERLMAN, and G. T. SEABORG. 1964. The Nuclear Properties of the Heavy Elements,Volume II. Englewood Cliffs, New Jersey: Prentice-Hall, Inc.

KRIEN, K., C. GUNTHER, J. D. BOWMAN, and B. KLEMME. 1970. Nucl. Phys., 141:75.

KRIEN, K., M. J. CANTY, and P. HERZOG. 1970. Nucl. Phys., 157:456.

LANGE, R. C. and G. R. HAGEE. 1969. Nucl. Phys., 124:412.

LEDERER, C. M., J. M. HOLLANDER, and I. PERLMAN. 1967. Table of Isotopes, Sixth Edition. New York, N.Y.: John Wiley and Sons, Inc.

LINGEMAN, E. W. A., J. KONIJN, P. POLAK, and A. H. WAPSTRA. 1969. Nucl. Phys.. 133:630.

NUC'LEAR DATA GROUP. 1969-72. Nuclear Data Sheets, Section B, Vols. 3-8. New York: Academic Press. 
PAKKANEN, A., J. KANTElE,, and P. SOUMINEN. 1969. Z. Physik., 218:273.

DE PINHO, A. G., E. F. DA SIlveirA, and N. L. DA COSTA. 1970. Phys. Rev. C2?, 572.

POLAK, R., A. H. WAPSTRA, and C. YTHIER. 1966. Private Communication in Nuclear Data, 1-5, K. Way, Editor. New York: Academic Press.

WAPSTRA, A. H. 1967. Nucl. Phys., 97:641.

WAY, K. Editor. 1965-68. Nuclear Data, Section A. Vols. 1-4. New York: Academic Press.

WAY, K., Editor. 1966-68. Nuclear Data, Section B, Vols. 1-2. New York: Academic Press.

WAY, K., Editor. 1968-72. Nuclear Data Tables, Section A, Vols. 5-10. New York: Academic Press.

WOLF; G. K. 1968. Nucl. Phys., 116:387.

YTHIER, C., J. DALMASSO, G. ARDISSON, H. MARIA, and H. FOREST. 1969. Compt. Rend. B269, 785. 


\section{APPENDIX C}

\section{LISTING AND DEFINITIONS OF $\mathrm{U}_{3} \mathrm{O}_{8}$ PREFIXES}

l) $\mathrm{cU}_{3} \mathrm{O}_{8}$ chemically determined using colorimetric technique

2) $\mathrm{fU}_{3} \mathrm{O}_{8}$ chemically determined using fluorimetric technique

3) $\mathrm{vU}_{3} \mathrm{O}_{8}$ chemically determined using volumetric technique

4) $\mathrm{xU}_{3} \mathrm{O}_{8}$ determined using $\mathrm{x}$-ray fluorescence technique

5) $\mathrm{nU}_{3} \mathrm{O}_{8}$ radiometrically determined using neutron activation technique

6) $\mathrm{SU}_{3} \mathrm{O}_{8}$ radiometrical1y determined using $\mathrm{NaI}(\mathrm{T} 1)$ KUT technique

7) $\mathrm{gU}_{3} \mathrm{O}_{8}$ radiometrically determined using $\mathrm{Ge}(\mathrm{Li})$ KUT technique

8) $\mathrm{rU}_{3} \mathrm{O}_{8}$ radiometrically determined using $\mathrm{Ge}(\mathrm{Li})$ direct ${ }^{235_{\mathrm{U}}}$ technique

9) $\mathrm{eU}_{3} \mathrm{O}_{8}$ radiometrically determined using total gamma technique 